\title{
Medicinal plants - prophylactic and therapeutic options for gastrointestinal and respiratory diseases in calves and piglets? A systematic review
}

Hannah Ayrle ${ }^{1,2^{*}}$, Meike Mevissen², Martin Kaske², Heiko Nathues ${ }^{4}$, Niels Gruetzner ${ }^{4}$, Matthias Melzig ${ }^{5}$ and Michael Walkenhorst ${ }^{1}$

\begin{abstract}
Background: Gastrointestinal and respiratory diseases in calves and piglets lead to significant economic losses in livestock husbandry. A high morbidity has been reported for diarrhea (calves $\leq 35 \%$; piglets $\leq 50 \%$ ) and for respiratory diseases (calves $\leq 80 \%$; piglets $\leq 40 \%$ ). Despite a highly diverse etiology and pathophysiology of these diseases, treatment with antimicrobials is often the first-line therapy. Multi-antimicrobial resistance in pathogens results in international accordance to strengthen the research in novel treatment options. Medicinal plants bear a potential as alternative or additional treatment. Based on the versatile effects of their plant specific multi-component-compositions, medicinal plants can potentially act as 'multi-target drugs'. Regarding the plurality of medicinal plants, the aim of this systematic review was to identify potential medicinal plant species for prevention and treatment of gastrointestinal and respiratory diseases and for modulation of the immune system and inflammation in calves and piglets.
\end{abstract}

Results: Based on nine initial sources including standard textbooks and European ethnoveterinary studies, a total of 223 medicinal plant species related to the treatment of gastrointestinal and respiratory diseases was identified. A defined search strategy was established using the PRISMA statement to evaluate 30 medicinal plant species starting from 20'000 peer-reviewed articles published in the last 20 years (1994-2014). This strategy led to 418 references (257 in vitro, 84 in vivo and 77 clinical trials, thereof 48 clinical trials in veterinary medicine) to evaluate effects of medicinal plants and their efficacy in detail. The findings indicate that the most promising candidates for gastrointestinal diseases are Allium sativum L., Mentha x piperita L. and Salvia officinalis L.; for diseases of the respiratory tract Echinacea purpurea (L.) MOENCH, Thymus vulgaris L. and Althea officinalis L. were found most promising, and Echinacea purpurea (L.) MOENCH, Camellia sinensis (L.) KUNTZE, Glycyrrhiza glabra L. and Origanum vulgare L. were identified as best candidates for modulation of the immune system and inflammation.

Conclusions: Several medicinal plants bear a potential for novel treatment strategies for young livestock. There is a need for further research focused on gastrointestinal and respiratory diseases in calves and piglets, and the findings of this review provide a basis on plant selection for future studies.

Keywords: Medicinal plants, Calves, Piglets, Gastrointestinal diseases, Respiratory diseases

\footnotetext{
* Correspondence: hannah.ayrle@fibl.org

'Department of Livestock Sciences, Research Institute of Organic Agriculture

(FiBL), Ackerstrasse 113, postbox 219, Frick 5070, Switzerland

2Division Veterinary Pharmacology \& Toxicology, Department Clinical

Research and Veterinary Public Health, Vetsuisse Faculty, University of Bern,

Laenggassstrasse 124, Bern 3012, Switzerland

Full list of author information is available at the end of the article
} 


\section{Background}

A high standard of animal health and welfare is striven in modern livestock husbandries. Health in early life represents a precondition for a superior constitution and results in a high productivity later in life. The mammalian immune system is still immature in the first weeks of life and, in combination with an inappropriate colostral supply, contact to pathogens often results in high morbidity and mortality in young farm animals. Inadequate management including long distance transports, fasting, commingling of individuals from different sources, abrupt changes in diet or incorrect diet, overcrowding of pens, improper climate and suboptimal hygiene are crucially involved in infectious diseases [1-6]. In calves and piglets, the first contact sites for pathogens are the epithelia of the gastrointestinal and respiratory tract. Table 1 shows four of the most important infectious disease complexes in calves and piglets leading to a decreased animal performance and welfare and therefore high economic losses.

In calves and piglets, a variety of pathogens can cause gastrointestinal diseases. Neonatal calf diarrhea represents the most frequent cause of calf losses [2, 7-9] with a mortality of around $55 \%$ in the U.S.A. and in Korea [10] and a morbidity ranging from $12 \%$ in the U.S.A., $23 \%$ in Canada up to $53 \%$ in The Netherlands $[1,7,11]$. Insufficient colostral supply and failure of feeding or improper diet are triggers for diarrhea in calves [12-14]. In suckling and postweaning piglets an infection with enterotoxigenic Escherichia coli strains has been reported to lead to high economic losses as a result of a constant high morbidity and mortality [15]. Verocytotoxin-producing Escherichia coli infections can lead to more seldom but severe edema disease in weaned pigs [16-18]. The prevalence of postweaning diarrhea has been reported to be $35 \%$ in France [19], the morbidity was stated to exceed $50 \%$ in Finland [20] and the mortality can be as high as $25 \%$ without therapy [17]. The incidence of neonatal diarrhea in piglets depends on concentration of antibodies in sow's colostrum. While piglets are protected by the antibodies in sow's milk, the predisposition for postweaning diarrhea increases with weaning. Additional factors to the immunological gap, including abrupt changes in diet, an increase in stomach $\mathrm{pH}$, and changes in the enzymatic and cellular configuration of the intestine lead to dysbiosis $[6,17,21]$.

Respiratory diseases in calves and piglets have been assessed as one of the most serious diseases with regard to financial losses because of decreased weight gain, costs for veterinary interventions and higher condemnation at slaughter [22]. In fattening calves bovine respiratory disease is a considerable challenge with a morbidity ranging from $49 \%$ in Switzerland to $80 \%$ in the U.S.A. $[23,24]$. There is a disposition of the bovine respiratory tract to respiratory diseases. Improper microclimate, noxious gases and distress through transportation are predisposing factors additionally $[25,26]$. Respiratory diseases are also of high importance in pigs. The morbidity rates differ between countries; a morbidity of 10 and $40 \%$ have been reported for Denmark and the U.S.A. respectively [27, 28]. Mortality rates up to $15 \%$ [29] have been reported and attributed with the porcine respiratory disease complex. The interaction of various pathogens as well as housing conditions, management and genetic factors, were reported to cause bronchopneumonia [27, 29].

Antibiotic therapy is often the first-line therapy of diseases of the gastrointestinal and respiratory tract in calves and piglets. A previously published study showed that fattening calves receive antibiotics for 30 days on average. Moreover, calves are frequently treated with reserve antibiotics such as fluorchinolones and cephalosporines of the 3 . and 4. generation [30]. In pig production, routine proand metaphylactic administration of antimicrobial agents is a widely-used practice in herds suffering from neonatal diarrhea, postweaning diarrhea or edema disease irrespective of increasing ineffectiveness in consequence of bacterial resistance [6]. More than $60 \%$ of the antibiotics used in porcine husbandry are administered by oral group treatment [31]. Data on antimicrobial resistance monitoring indicated that $59 \%$ of porcine Escherichia coli strains from fecal samples showed resistance to at least one antibiotic and $12 \%$ to more than four of the antibiotics that were investigated [32]. With regard to increasing antimicrobial resistance worldwide, the prevailing issue of reducing antibiotics in food producing animals is seeking for novel options to prevent and cure most common and costly diseases. Improved biosecurity and housing conditions, new feeding regimes, vaccinations and the use of disease-resistant breeds are important provisions.

The diverse etiopathology and symptomatology of diseases in young stock is a challenge and demands a multitargeted therapy. In contrast to chemically synthesized mono-target drugs, multi-target drug characteristics are typical for medicinal plants based on their multicomponent composition, which can lead to pleiotropic, synergistic or additive effects in the organism [33, 34]. The broad spectrum of natural products from plants represents a prevailing and widely unemployed potential especially for medication of herbivore and omnivore livestock [35]. Medicinal plants have been used worldwide for prevention and treatment of diseases in human and animals for centuries. Ethnoveterinary research and the underlying documents describing traditional and recent use of medicinal plants [36-38] could be exploited as alternative or as supportive tools to reduce the use of antibiotics in livestock. Additionally, some medicinal plants are known to modulate the immune system and inflammation and could be used as a prophylaxis for infectious diseases.

Human clinical studies, experimental in vivo, ex vivo and in vitro studies on medicinal plants are available, 
Table 1 Challenging infectious diseases in calves and piglets: pathogens, pathophysiology, resulting demands for prophylaxis and therapy

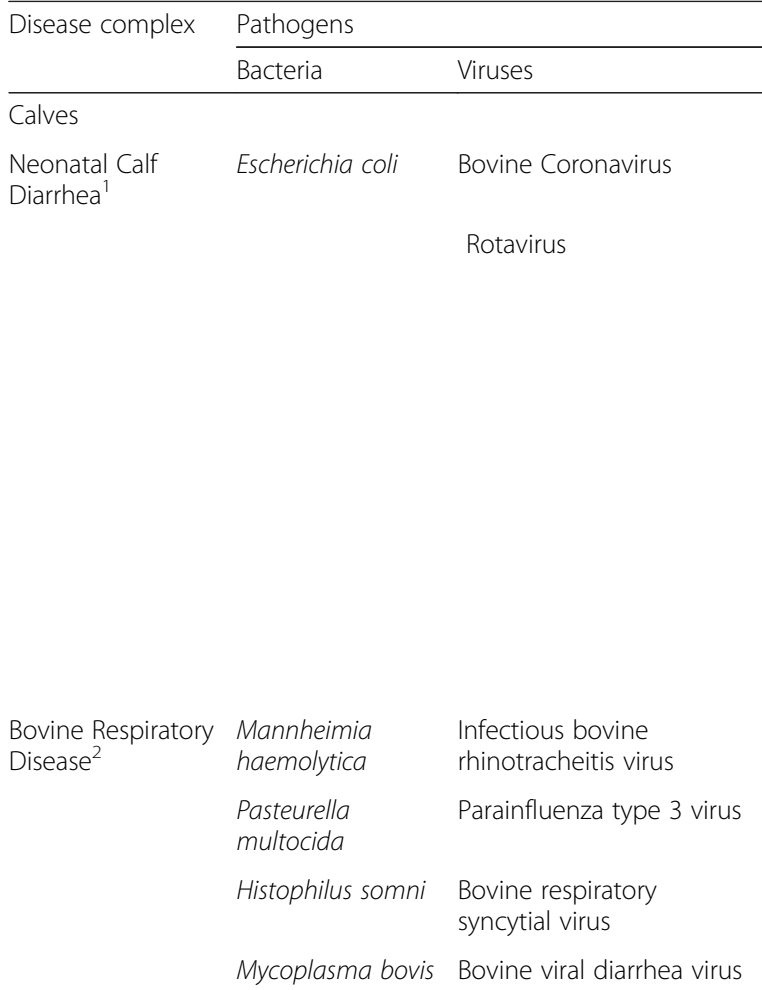

Piglets

\begin{tabular}{|c|c|c|}
\hline Neonatal Diarrhea & Escherichia coli & Rotavirus \\
\hline \multirow[t]{5}{*}{$\begin{array}{l}\text { Postweaning } \\
\text { Diarrhea }^{3}\end{array}$} & $\begin{array}{l}\text { Clostridium } \\
\text { perfringens }\end{array}$ & Coronavirus \\
\hline & $\begin{array}{l}\text { Lawsonia } \\
\text { intracellularis }\end{array}$ & Porcine Circovirus type 2 \\
\hline & Brachyspira spp. & \\
\hline & Salmonella spp. & \\
\hline & (Yersinia spp.) & \\
\hline \multirow[t]{3}{*}{$\begin{array}{l}\text { Porcine respiratory } \\
\text { disease complex }\end{array}$} & $\begin{array}{l}\text { Pasteurella } \\
\text { multocida }\end{array}$ & $\begin{array}{l}\text { Porcine reproductive and } \\
\text { respiratory syndrome virus }\end{array}$ \\
\hline & $\begin{array}{l}\text { Mycoplasma } \\
\text { hyopneumoniae }\end{array}$ & Swine influenza virus \\
\hline & & Porcine circovirus type 2 \\
\hline
\end{tabular}

Pathophysiology/pathogenesis Demands for prophylaxis and therapy Parasites

Cryptosporidium
parvum

secretory/malabsorptive/

antimicrobial maldigestive diarrhea

dehydration

antiviral

hypovolemic shock

antidiarrheal

decrease in temperature

antiadhesive

d-lactat acidosis

astringent

septicaemia

spasmolytic

neurological symptoms

analgesic

apathy

anti-inflammatory

recumbency

orexigenic

reluctance to drink

prebiotic

fever

immunostimulant

catharral/interstitial/fibrinous

antimicrobial

bronchopneumonia

fever

antiviral

increased respiratory rate

analgesic

dyspnoea

anti-inflammatory

inappetence

nasal discharge

coughing

apathy

immunostimulant

mucolytic

secretolytic

antitussive

runting

Cryptosporidium spp.

secretory/malabsorbtive/ maldigestive diarrhea

antimicrobial

Isospora suis

enteritis

antiviral

Trichuris suis

colitis

antidiarrheal

Oesophagostomum dentatum

dehydration

antiadhesive

acidosis

astringent

septicaemia

spasmolytic

neurological symptoms

apathy

analgesic

anti-inflammatory

reduced growth rates

orexigenic

prebiotic

immunostimulant

suppurative/fibrinous/interstitial antimicrobial bronchopneumonia

coughing

antiviral

nasal discharge

analgesic 
Table 1 Challenging infectious diseases in calves and piglets: pathogens, pathophysiology, resulting demands for prophylaxis and therapy (Continued)

\begin{tabular}{|c|c|c|}
\hline \multicolumn{3}{|c|}{$\begin{array}{l}\text { Actinobacillus } \\
\text { pleuropneumoniae }\end{array}$} \\
\hline $\begin{array}{l}\text { (Streptococcus } \\
\text { suis) }\end{array}$ & increased respiratory rate & anti-inflammatory \\
\hline \multirow{4}{*}{$\begin{array}{l}\text { (Haemophilus } \\
\text { parasuis) }\end{array}$} & fever & immunostimulant \\
\hline & reduced growth rates & mucolytic \\
\hline & runting & secretolytic \\
\hline & & antitussive \\
\hline
\end{tabular}

$\left.{ }^{1}[10-13]^{2}[3-5,23,25]^{3}[6,15-18]\right]^{4}[22,27,29]$

but there is a lack of comprehensive research for veterinary medicine, especially in young farm animals. Therefore, the purpose of the underlying work is to gain information about potential efficacy of medicinal plants in human and veterinary medicine including in vitro, in vivo and clinical studies.

The aim of this systematic literature review is to identify medicinal plant species or their extracts that are promising candidates for use in diseases of the gastrointestinal and respiratory tract and for stimulation of the immune system and prevention or therapy of inflammation in calves and piglets. Candidate plants should bear a reliable potential for effective treatment and prevention of these diseases. The information obtained can build a basis for state-of-the-art experimental trials and clinical studies with medicinal plants of interest for the treatment of gastrointestinal and respiratory diseases and for the modulation of the immune system and inflammatory processes in calves and piglets.

\section{Methods}

The design of the systematic review was 'a priori' individually developed according to the recommendations of the PRISMA statement $[39,40]$ and AMSTAR measurement tool [41]. The research question was designed following the PICOS scheme [39]: the population are calves and piglets in livestock farming, the intervention is a treatment with medicinal plants, the comparator is no treatment, a placebo or standard treatment, the outcome is the effect of the plant, the study design included in vitro, ex vivo, in vivo and clinical trials. The detailed protocol of the systematic review is provided in the Additional file 1.

\section{Selection of plant species}

To choose eligible plant species, different initial sources were screened in respect to plant species frequently recommended for the treatment of gastrointestinal diseases, particularly unspecified or infectious diarrhea and gastrointestinal spasms (QA) and respiratory diseases $(\mathrm{QR})$ as well as those plants that have been reported to modulate the immune system and affect inflammation in infectious diseases (QL). Regarding the intended use of medicinal plants in Western livestock husbandry, potential plant species should be economically available or easy to cultivate in Europe. The initial sources included standard literature, based on traditional empiric knowledge and historical literature of veterinary [42-45], and human phytotherapy [46], peer-reviewed publications of European [47] and in particular Swiss ethnoveterinary medicine [36, 38] and a report of the European Food Safety Authority (EFSA) [48] focusing on the use of plants as feed additives in animal production. All plant species of these sources connected to one or more of the indications were recorded including the used part(s) of plant, the route of administration, the dosage, the contraindications and adverse effects (Additional file 1). Based on the plant species that had been mentioned in at least three different initial sources for the same indication, a preliminary selection was established. This selection was sent to three specialists in European veterinary phytotherapy to capitalize their experience. The experts were asked to comment on the preliminary selection of plant species regarding the most common ones being particularly suitable for treatment and prevention of gastrointestinal and respiratory diseases.

\section{Selection of scientific references Bibliographic search}

The chosen plant species were included in the following step. A bibliographic web-based search was conducted based on the recommendations of the PRISMA statement $[39,40]$ and AMSTAR measurement tool [41]. An introduction in scientific bibliographic literature searches and continuous support was provided by a professional librarian. The bibliographic sources used included PubMed [49] and Web of Science [50]. Both were consulted in the time between 2015-02-16 and 2015-02-19 by one person. The search terms consisted of the Latin name, the common trivial name in English and the pharmaceutical denomination in Latin (e.g. "Foeniculum vulgare" OR "fennel" OR "foeniculi fructus"). In the PubMed keyword search, the results were refined with the subjects 'complementary 
medicine,' 'dietary supplements,' 'systematic review', 'toxicology' and 'veterinary science'. In the PubMed search with MeshTerms, only the Latin name of the plant was used and the subheadings 'adverse effects,' 'analysis', 'drug effects', 'microbiology', 'pharmacology', 'therapeutic use,' 'therapy' and 'toxicity'. In the Web of Science database, the search was conducted in the research domain 'science technology' and the results were refined with the research areas 'pharmacology', 'infectious diseases,' 'toxicology', 'veterinary sciences,' 'microbiology', 'gastroenterology', 'integrative complementary medicine,' 'general internal medicine,' 'respiratory system' and 'virology'. Overall, only peer-reviewed articles written in English or German language and published between 1994 and 2014 were considered for further evaluation to ensure contemporary scientific quality and timeliness of the review. The references found were saved in an EndNote X7 data base [51] and the information on each plant was stored in a separate folder in this database. Duplicates were removed for each plant species.

In some studies more than one plant species was investigated (e. g. a screening of plant species against $E$. coli [52]). In other studies, more than one indication was considered and investigated (e. g. spasmolytic effect of Plantago lanceolata L. on intestine and trachea [53]). Therefore, the following definition of "reference" was introduced:

reference $=$ indication per plant species per peerreviewed publication

\section{Term-list search}

A term-list search was conducted within each plant species using the search function in EndNote X7 [51]. Only references containing one of the following predefined keywords occurring in the title or the abstract were included: 'pig",'calv"','muco"', 'spasmo"', anti"' (e.g. antimicrobial, antibacterial, antiviral, antifungal, antioxidant, antinociceptive...), 'wean"', 'intest"', 'gastro"', 'pulmo*', 'broncho"', 'pharma"', 'eff"'(e.g. efficiency, effectivity, effect), 'bioactiv", 'constitu"'. References containing the terms 'tumor' or 'cancer' were excluded. The check of the excluded references lowered the risk to exclude relevant references.

\section{Refining with inclusion and exclusion criteria}

The remaining references were refined using a selective screening of the title. References remained if the content suffices the objective of the review. Therefore, inclusion criteria were pre-defined by two scientists and lead to an inclusion of all references containing investigations of plants in in vitro, ex vivo, in vivo or clinical studies. Besides these categories, the evaluation included the following inclusion criteria: antibacterial effect, enhancement of antibiotics, antiviral effect, antiprotozoal effect, anti-inflammatory effect, analgesic effect, spasmolytic effect, antiadhesive effect, astringent effect, secretolytic or mucolytic effect, antitussive effect, and other effects on the gastrointestinal tract, respiratory tract or immune system, treatment of diarrhea, bacterial or viral infections of the gastrointestinal tract or respiratory tract, bronchopneumonia, common cold, cough as well as ingredients, constituents, components of plants and the detection or extraction of them, toxic activity or adverse effects due to a treatment with plants.

Exclusion criteria were chosen in order to exclude references dealing with other plant species or subspecies than those we focused on, a mixture of different plant species investigated as one single preparation, pathogens affecting only humans, diseases regulated by laws, cultivation or breeding of plants, plant genetics, seeds and fertilizers, regional reservoirs, habitats or demands for growing of plants, plant pathology, plant protection systems or pesticides, ecology, geology, ethology, sociology, the usage of the plant as food, food technology or food-packaging, the use of the plant as a repellent or insecticide, other medical branches, other diseases or apparatuses than mentioned in the inclusion criteria (e.g. dermatology, cardiology, oncology, nephrology, diabetes) as well as other animal classes than mammalians and birds.

\section{Classification}

Thereby the references were classified into different categories of trial types. Studies investigating diseases occurring naturally in the investigated animal species or in humans were categorized as 'clinical references'. Trials investigating diseases or the effect of plants in animal models were categorized as 'in vivo references'. Studies using pathogens, cell layers or ex vivo models were categorized as 'in vitro references'. Studies investigating the pharmacologic characteristics, constituents or the detection of them were categorized as 'pharmacognostic references' and the evaluation of plants summarizing other studies as 'review references'.

In the last step, abstracts of the remaining clinical, in vivo and in vitro references were studied by one person. During this process, further references were excluded because they did not match the predefined selection criteria.

\section{Assessment of clinical, in vivo and in vitro references}

The remaining references were assessed by the following characteristics: used plant species, type of reference (clinical, in vivo or in vitro), indication of the reference inspired by the ATCvet classification (QA, QR, QL) [54], animal species used, study design, pharmaceutical form of the plant, type of application, concentration tested, dosage or minimal inhibition concentration and, if available, the tested pathogen.

To assess the potential of the selected plant species, a reconciliation of the demands for prophylaxis and therapy of gastrointestinal and respiratory diseases with the 
hypothesized and tested effects of the plants was performed. The demands for prophylaxis and therapy were derived from the pathophysiology of the focused diseases (Table 1). According to these data, plant-derived treatment options should act bacteriostatic or bactericidal, synergistically with antibiotics, antiviral, antiprotozoal, antiinflammatory, analgesic, immunomodulatory, antidiarrheal, antiadhesive, spasmolytic, astringent, expectorant or antitussive (depending on the indication). The conclusion of a trial on the investigated hypothesized effect of the plant species (Additional file 3) was transferred in the following assessment. To compare the potential of the plant species, a scoring system was established. For each significantly proven effect, the plant species one point was given, while for each uncertain effect, zero points were assigned, and for each disproved effect a point was subtracted (for more details see Additional file 1). Clinical studies were given more weight compared to in vivo studies followed by in vitro studies. Clinical studies were given a weight of three, in vivo studies two, and in vitro studies one. The weighted average of the sum of points of the clinical, in vivo, and in vitro scores served as the final score. The scores were used to identify the plant species that are the most efficacious options for related disease complexes.

$$
\begin{gathered}
\text { Score }=3 \times \text { (number of proven effects in clinical studies - } \\
\text { number disproof of effects in clinical studies) }+ \\
2 \times \text { (number of proven effects in in vivo studies - } \\
\text { number ofdisproof of effects in in vivo studies) }+ \\
1 \times \text { (number of proven effects in in vitro studies- } \\
\text { number of disproof of effects of in vitro studies) }
\end{gathered}
$$

\section{Results}

The procedure of this systematic literature review is visualized in Fig. 1. The screening of ethnoveterinary research and standard phytotherapeutic textbooks (initial sources) led to a total of 223 plant species recommended for the treatment and prophylaxis of gastrointestinal (diarrhea and intestinal spasms) and respiratory diseases in human and animals. A number of 134 different plant species were recommended for QA, 121 for QR and 44 for QL (Additional file 2). A preliminary selection of 29 plant species, recommended in at least three different sources for the same indication, was established. Therefrom, 17 plant species were recommended for QA, 15 for QR and 8 for QL. The specialists review led to an addition of one plant species (Origanum vulgare L.) to the preliminary list including finally 30 plant species. All of these plant species meet the claims for cost-efficiency or cultivability in Europe.

In the subsequent bibliographic search 20,364 references (after removal of duplicates) were found for the 30 plants species (Table 2). During the term-list search, the amount of relevant references led to a reduction of references with 6,800 remaining references. An ensuing random check of the excluded references confirmed the selected terms. The subsequent screening of titles led to a number of 2,797 eligible references, which were classified into the categories 'clinical references' (243), 'in vivo references' (428), 'in vitro references' (1258), 'pharmacognostic references' (704) and 'review references' (164). The terminal screening of the abstracts of all clinical, in vivo and in vitro references revealed a final number of 418 references (77 clinical, 84 in vivo, 258 in vitro) (Additional file 3). Due to the fact that more than one reference could be defined from some studies, the systematic literature research led to a number of 378 studies representing the effects and efficacy of 29 plant species in 418 references. For one plant species, Quercus robur L., no references were found according to the criteria.

A total of 19,077 references were excluded because they did not match the predefined selection criteria. Predominant reasons for exclusion included that the content of title and abstract did not correspond to the focus of the review (e. g. pathogens were not the pathogens of the focused diseases). Other reasons were missing abstracts (in 212 references) or publications that were not peer-reviewed.

From the 418 remaining references, 48 references based on clinical studies were veterinary origin with 19 swine studies, 5 cattle studies, 17 horse studies, and 4 studies in rabbits. A number of 370 references include studies in humans (29 clinical, 84 in vivo and 257 in vitro studies). A number of 77 in vivo references used laboratory rodents (rats, mice, guinea-pigs) and three studies used cats as an animal model. For gastrointestinal indications (QA), 198 references were found, 57 references were related to respiratory diseases $(\mathrm{QR})$, and 163 references aimed at the modulation of the immune system and inflammation processes (QL). Most references coping with the inclusion criteria were found for Echinacea purpurea L. MOENCH. (48 references), Origanum vulgare L. (36 references) Thymus vulgaris L. (36 references), Camellia sinensis (L.) KUNTZE (32 references), and Allium sativum L. (31 references). The required effects of a treatment and the proven effects of the plant species as mono-substances for each indication are shown in Tables 3, 4 and 5. In Table 6, the most promising plant species of the peer-reviewed references according to the scoring system for each indication (QA, QR and $\mathrm{QL})$, as well as the most frequently recommended plant species of the traditional references (Additional file 2) are shown. According to the scoring system, the two most promising plant species are Echinacea purpurea (L.) MOENCH (for QR and QL) and Allium sativum L. (for QA).

\section{Discussion}

There is a large amount of evidence-based knowledge about medicinal plants, represented by 20,364 studies focusing on 30 medicinal plant species from the last 


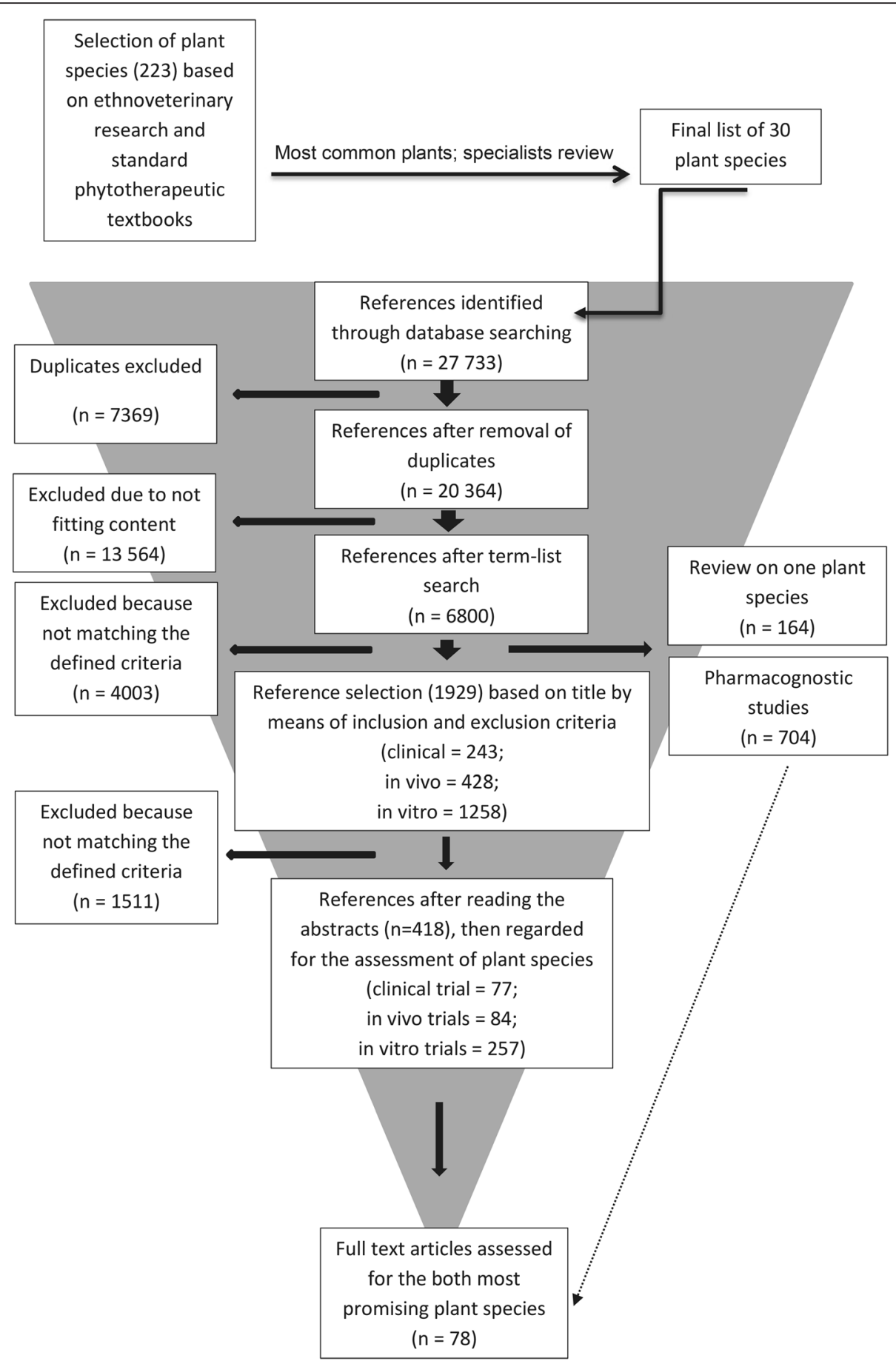

Fig. 1 Process of the systematic literature review

20 years considering peer-reviewed publications in English or German language. The emergence of multi-drug resistance in human and animal pathogens results in international accordance to strengthen the research in novel treatment options. Medicinal plants and their extracts might be an option to prevent and cure livestock diseases.

\section{Evaluation of the search strategy}

This systematic review was designed and performed according to the guidelines of the PRISMA statement and AMSTAR measurement tool [39-41]. Due to the fact that we searched for available data on a largely underrepresented topic in the last decades, only a small number of 
Table 2 Quantifying and categorizing of scientific publications regarding 30 medicinal plants during bibliographic literature research process

\begin{tabular}{|c|c|c|c|c|c|c|c|c|c|}
\hline Plant species & $\begin{array}{l}\text { Common } \\
\text { name }\end{array}$ & $\begin{array}{l}\text { All references } \\
\text { imported from } \\
\text { WoS }{ }^{1} \text { and } \mathrm{PM}^{2} \\
\text { after removal } \\
\text { of duplicates }\end{array}$ & $\begin{array}{l}\text { After keyword } \\
\text { search in titles } \\
\text { and abstracts } \\
\text { with endnote }\end{array}$ & $\begin{array}{l}\text { Pharmacognostic } \\
\text { studies }\end{array}$ & Reviews & $\begin{array}{l}\text { After checking } \\
\text { of relevance, } \\
\text { regarded for } \\
\text { the assessment } \\
\text { of plant species }\end{array}$ & $\begin{array}{l}\text { Clinical } \\
\text { studies }\end{array}$ & $\begin{array}{l}\text { In vivo } \\
\text { studies }\end{array}$ & $\begin{array}{l}\text { In vitro and } \\
\text { ex vivo } \\
\text { studies }\end{array}$ \\
\hline Achillea millefolium $\mathrm{L}$. & yarrow & 345 & 157 & 14 & 2 & 15 & 2 & 3 & 10 \\
\hline Agrimonia eupatoria L. & agrimony & 73 & 37 & 10 & 0 & 2 & 1 & 0 & 1 \\
\hline Allium sativum $\mathrm{L}$. & garlic & 1149 & 630 & 24 & 14 & 31 & 9 & 5 & 17 \\
\hline Althaea officinalis L. & marshmellow & 62 & 29 & 6 & 1 & 6 & 0 & 4 & 2 \\
\hline $\begin{array}{l}\text { Camellia sinensis (L). } \\
\text { KUNTZE }\end{array}$ & green tea & 2052 & 804 & 53 & 21 & 32 & 4 & 6 & 22 \\
\hline Carum carvi L. & caraway & 191 & 95 & 28 & 6 & 5 & 0 & 1 & 4 \\
\hline $\begin{array}{l}\text { Cetraria islandica (L.) } \\
\mathrm{ACH} \text {. }\end{array}$ & $\begin{array}{l}\text { Icelandic } \\
\text { moss }\end{array}$ & 118 & 46 & 8 & 0 & 4 & 1 & 1 & 2 \\
\hline $\begin{array}{l}\text { Echinacea purpurea (L.) } \\
\text { MOENCH }\end{array}$ & $\begin{array}{l}\text { purple } \\
\text { coneflower }\end{array}$ & 869 & 364 & 45 & 18 & 48 & 14 & 8 & 26 \\
\hline $\begin{array}{l}\text { Foeniculum vulgare (L.) } \\
\text { MILL. }\end{array}$ & fennel & 825 & 308 & 46 & 6 & 18 & 1 & 4 & 13 \\
\hline Glycyrrhiza glabra L. & liquorice & 597 & 252 & 43 & 8 & 26 & 3 & 7 & 16 \\
\hline Linum usitatissimum L. & linseed & 762 & 227 & 12 & 5 & 7 & 3 & 3 & 1 \\
\hline Malva sylvestris $\mathrm{L}$. & wild mallow & 243 & 50 & 2 & 2 & 4 & 0 & 3 & 1 \\
\hline Matricaria recutita L. & camomile & 908 & 305 & 43 & 7 & 22 & 1 & 7 & 14 \\
\hline Mentha x piperita $\mathrm{L}$. & peppermint & 1331 & 425 & 35 & 23 & 21 & 8 & 0 & 13 \\
\hline Origanum vulgare L. & oregano & 904 & 526 & 42 & 0 & 36 & 10 & 4 & 22 \\
\hline Picea abies (L.) H.KARST. & $\begin{array}{l}\text { norway } \\
\text { spruce }\end{array}$ & 1031 & 153 & 0 & 0 & 1 & 0 & 0 & 1 \\
\hline Pimpinella anisum $\mathrm{L}$. & anis & 453 & 147 & 12 & 2 & 12 & 2 & 0 & 10 \\
\hline Plantago lanceolata $\mathrm{L}$. & $\begin{array}{l}\text { english } \\
\text { plantain }\end{array}$ & 532 & 136 & 7 & 2 & 6 & 1 & 0 & 5 \\
\hline $\begin{array}{l}\text { Potentilla erecta (L.) } \\
\text { RAEUSCH. }\end{array}$ & tormentil & 49 & 15 & 3 & 2 & 3 & 2 & 0 & 1 \\
\hline Primula veris $\mathrm{L}$. & cowslip & 106 & 23 & 2 & 0 & 1 & 0 & 0 & 1 \\
\hline Quercus robur L. & english oak & 1210 & 165 & 7 & 0 & 0 & 0 & 0 & 0 \\
\hline Rubus fruticosus L. & blackberry & 583 & 172 & 34 & 0 & 6 & 0 & 1 & 5 \\
\hline Rumex ssp. L. & dock & 939 & 208 & 15 & 2 & 11 & 0 & 4 & 7 \\
\hline Salix ssp. L. & willow & 915 & 171 & 20 & 13 & 6 & 0 & 1 & 5 \\
\hline Salvia officinalis $\mathrm{L}$. & sage & 902 & 372 & 67 & 5 & 20 & 7 & 7 & 6 \\
\hline Sambucus nigra L. & elderberry & 891 & 169 & 19 & 4 & 7 & 1 & 2 & 4 \\
\hline Thymus vulgaris $\mathrm{L}$. & thyme & 831 & 372 & 52 & 3 & 36 & 6 & 2 & 28 \\
\hline Tussilago farfara L. & coltsfoot & 101 & 36 & 14 & 0 & 4 & 0 & 1 & 3 \\
\hline Urtica dioica L. & $\begin{array}{l}\text { stinging } \\
\text { nettle }\end{array}$ & 760 & 251 & 16 & 10 & 20 & 1 & 6 & 13 \\
\hline Vaccinium myrtillus L. & blueberry & 632 & 155 & 25 & 7 & 8 & 0 & 4 & 4 \\
\hline sum $^{a}$ & & 20364 & 6800 & 704 & 164 & 418 & 77 & 84 & 257 \\
\hline
\end{tabular}

${ }^{a}$ due to the definition of reference (trial $\mathrm{x}$ plant species $\mathrm{x}$ indication) the sum may contain some trials more than one time; ${ }^{1}$ WoS $=$ Web of Science [50]; ${ }^{2} \mathrm{PM}=$ PubMed [49]

veterinary clinical data is currently available. Therefore, the search strategy was adapted to gain as much plant specific information as possible and to cope with the complex research question. Human clinical studies, experimental in vivo studies with laboratory animals as well as ex vivo and in vitro studies were included as well. To avoid the 
Table 3 Assessment $^{\mathrm{a}}$ of medicinal plants based on peer-reviewed references ${ }^{\mathrm{b}}$ of the last 20 years aiming gastrointestinal indications ${ }^{\complement}$

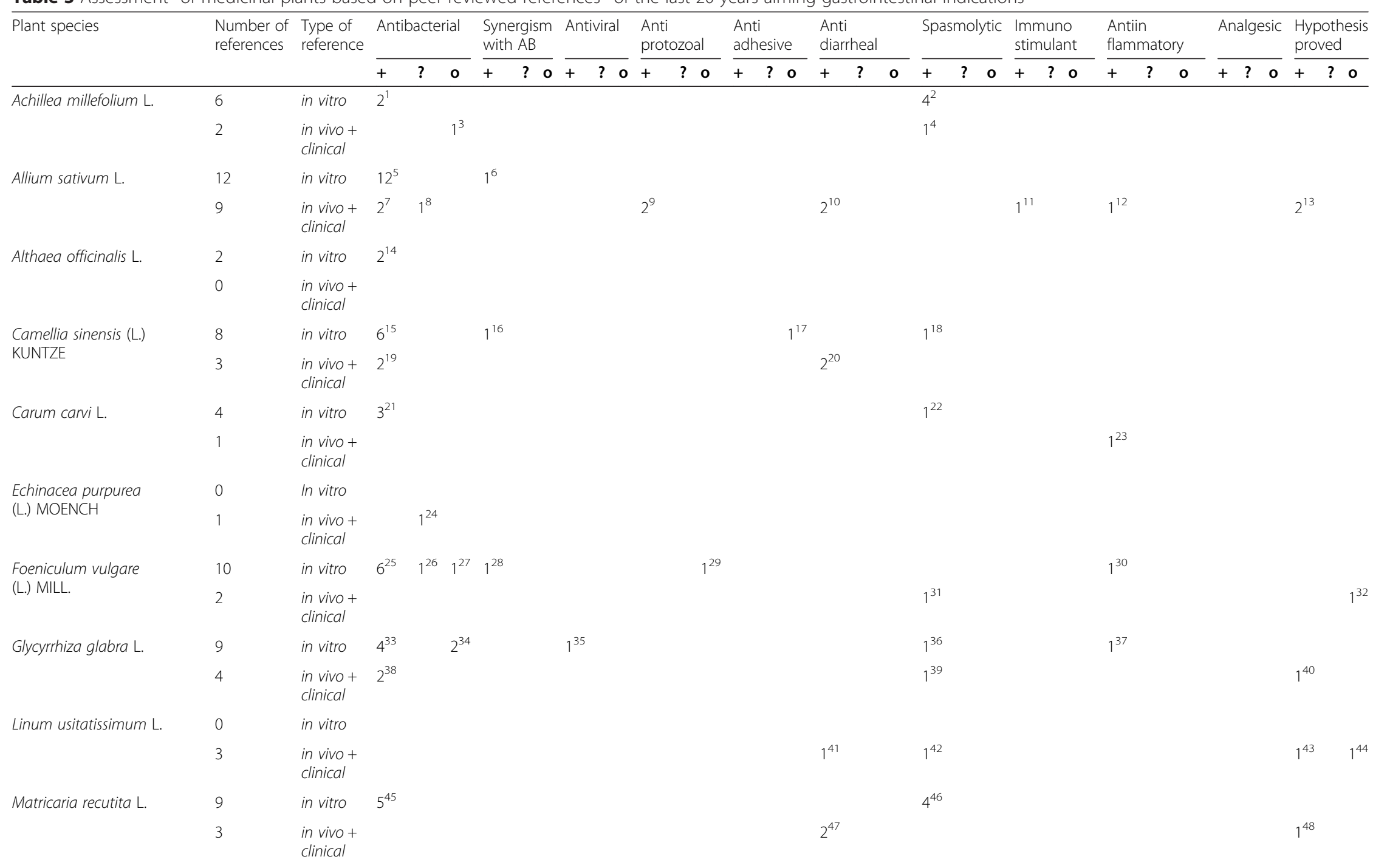


Table 3 Assessment ${ }^{\mathrm{a}}$ of medicinal plants based on peer-reviewed references ${ }^{\mathrm{b}}$ of the last 20 years aiming gastrointestinal indications $s^{\mathrm{c}}$ (Continued)

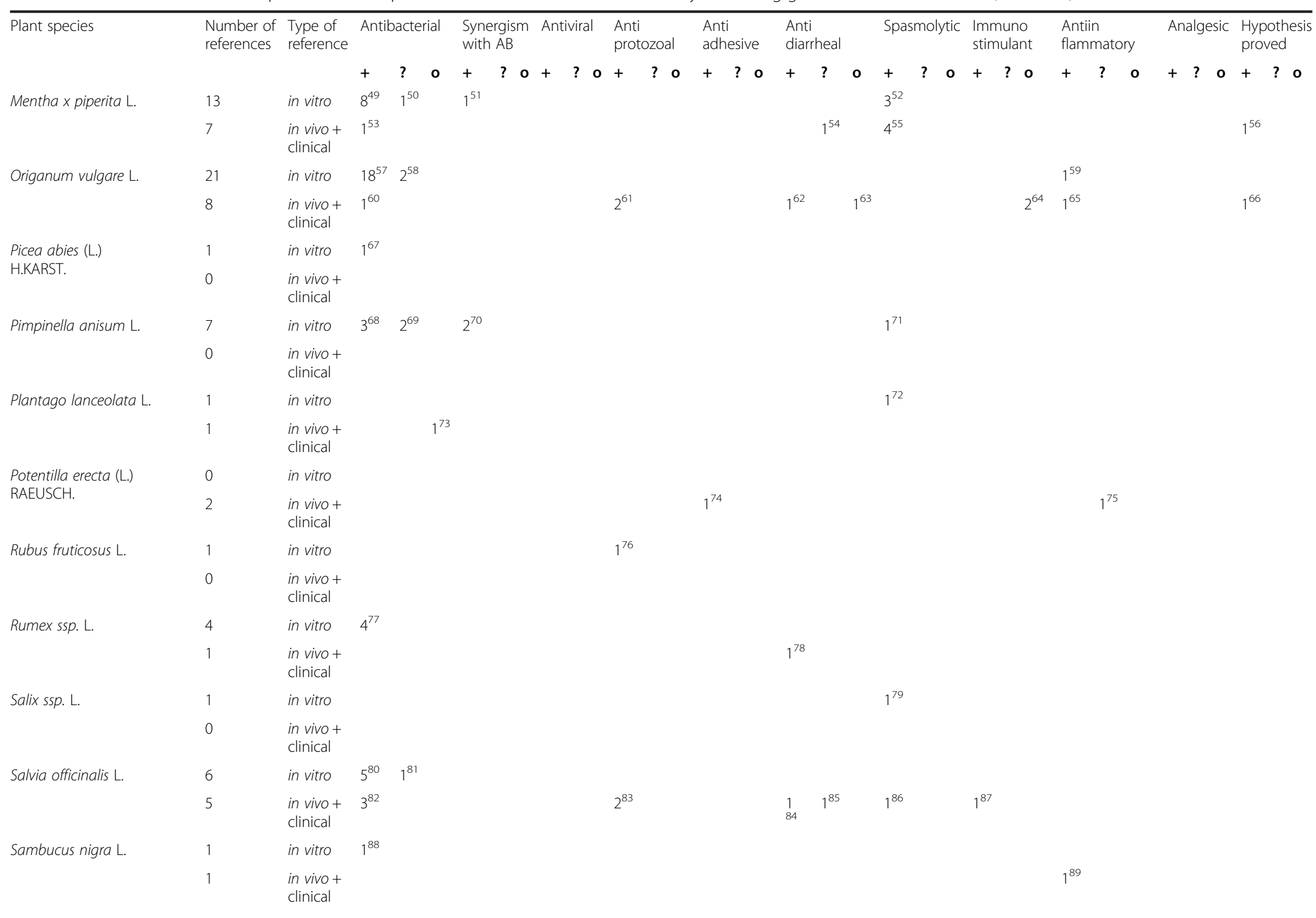


Table 3 Assessment ${ }^{\mathrm{a}}$ of medicinal plants based on peer-reviewed references ${ }^{\mathrm{b}}$ of the last 20 years aiming gastrointestinal indications ${ }^{\mathrm{c}}$ (Continued)

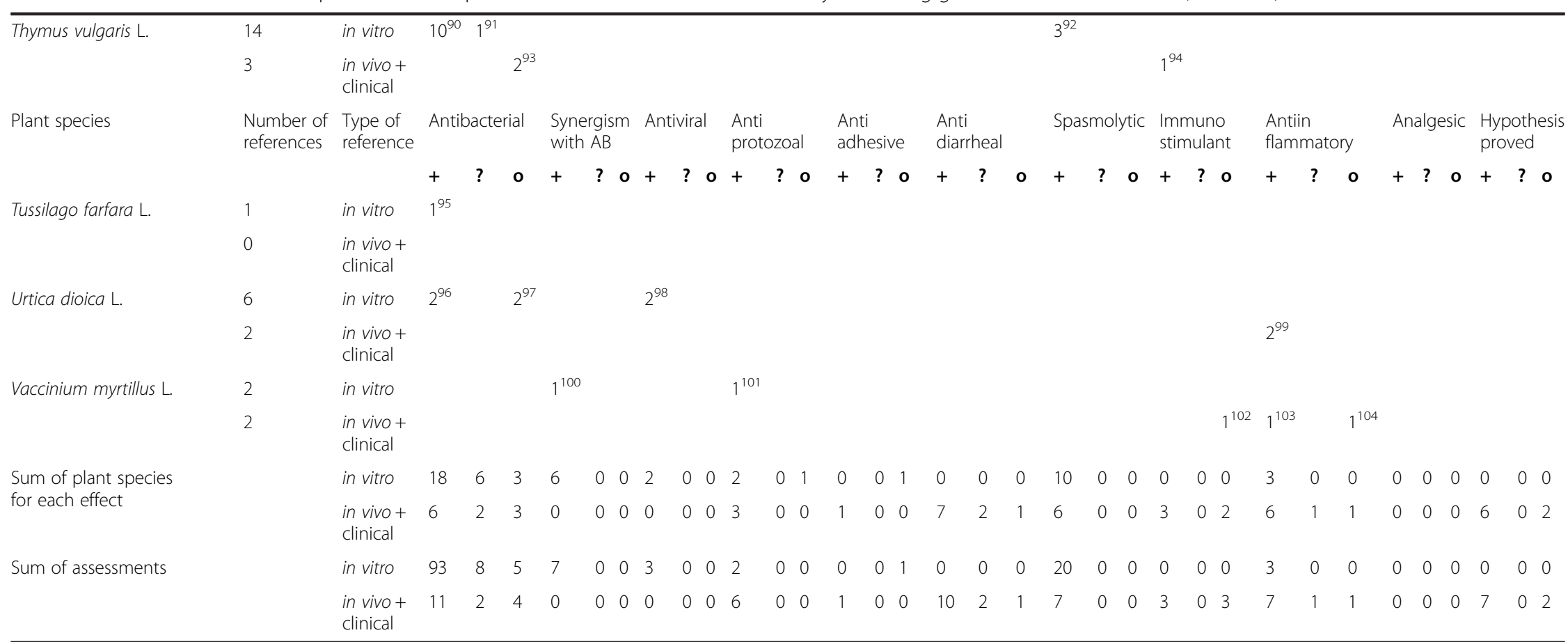

${ }^{a}$ Assessment $=$ conclusion of a reference on a hypothesized effect; ${ }^{b}$ reference $=$ trial $\mathrm{x}$ plant species $\mathrm{x}$ indication; ${ }^{\mathrm{c}}$ particularly unspecified or infectious diarrhea and gastrointestinal spasms $+=$ reference proves evidently the hypothesized effect; $?=$ reference shows uncertain hypothesized effect; $\mathbf{0}=$ reference does not prove evidently the hypothesized effect

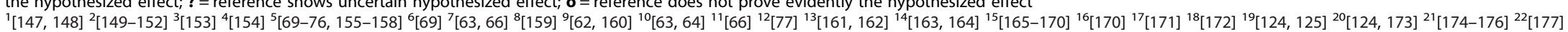

$\left.{ }^{23}[178]^{24}[179]{ }^{25}[175,176,180-183]^{26}[184]^{27}[185]^{28}[181]^{29}[186]^{30}[187]^{31}[188]^{32}[189]^{33}[143,190-192]^{34}[142,193]^{35}[145]^{36}[194]^{37}[195]^{38}[196,197]\right]^{39}[141]^{40}[198]{ }^{41}[199]^{42}[199]^{43}[200]{ }^{44}[201]^{45}[202][175,185$,

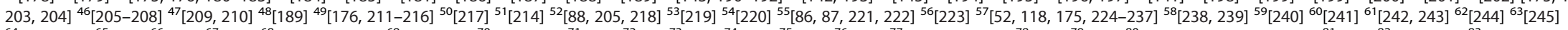

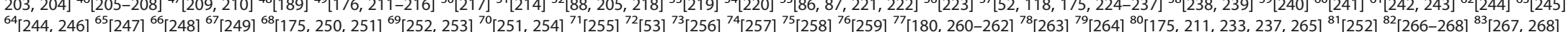

${ }^{84}[269]^{85}[270]^{86}[269]^{87}[268]^{88}[271]^{89}[272] 90[52,118-120,175,176,226,250,252,273]^{91}[274]^{92}[113,275,276]^{93}[277,278]^{94}[279]^{95}[280]^{96}[191,281]^{97}[185,282]^{98}[145]^{99}[283,284]^{100}[285]^{101}[259]^{102}[286]$

${ }^{103}[287]{ }^{104}[286]$ 
Table 4 Assessment ${ }^{\mathrm{a}}$ of medicinal plants based on peer-reviewed references ${ }^{\mathrm{b}}$ of the last 20 years aiming respiratory indications

\begin{tabular}{|c|c|c|c|c|c|c|c|c|c|c|c|c|c|c|c|c|c|c|c|c|c|c|c|c|c|c|c|c|c|c|c|}
\hline \multirow[t]{2}{*}{ Plant species } & \multirow[t]{2}{*}{$\begin{array}{l}\text { Number of } \\
\text { references }\end{array}$} & \multirow[t]{2}{*}{$\begin{array}{l}\text { Type of } \\
\text { reference }\end{array}$} & \multicolumn{3}{|c|}{ Anti-bacterial } & \multicolumn{3}{|c|}{$\begin{array}{l}\text { Synergism } \\
\text { with } A B\end{array}$} & \multicolumn{3}{|c|}{ Antiviral } & \multicolumn{3}{|c|}{ Spasmolytic } & \multicolumn{3}{|c|}{ Expectorant } & \multicolumn{3}{|c|}{ Antitussive } & \multicolumn{3}{|c|}{ Immuno-stimulant } & \multicolumn{3}{|c|}{ Anti-inflammatory } & \multicolumn{2}{|c|}{ Analgesic } & \multicolumn{3}{|c|}{$\begin{array}{l}\text { Hypothesis } \\
\text { proved }\end{array}$} \\
\hline & & & + & $?$ & 0 & + & $?$ & 0 & + & $?$ & o & + & $?$ & $\overline{0}$ & + & $?$ & $\overline{0}$ & + & $?$ & $\overline{0}$ & + & $?$ & 0 & + & $?$ & o & + & $\begin{array}{lll}? & 0\end{array}$ & + & $?$ & o \\
\hline \multirow[t]{2}{*}{ Achillea millefolium L. } & 2 & in vitro & & & & & & & & & & $2^{1}$ & & & & & & & & & & & & & & & & & & & \\
\hline & 1 & in vivo + clinical & & & & & & & & & & $1^{2}$ & & & & & & & & & & & & & & & & & & & \\
\hline \multirow[t]{2}{*}{ Agrimonia eupatoria L. } & 1 & in vitro & & & & & & & $1^{3}$ & & & & & & & & & & & & & & & & & & & & & & \\
\hline & 0 & in vivo + clinical & & & & & & & & & & & & & & & & & & & & & & & & & & & & & \\
\hline \multirow[t]{2}{*}{ Allium sativum $\mathrm{L}$. } & 1 & in vitro & & & & & & & & & & $1^{4}$ & & & & & & & & & & & & & & & & & & & \\
\hline & 0 & in vivo + clinical & & & & & & & & & & & & & & & & & & & & & & & & & & & & & \\
\hline \multirow[t]{2}{*}{ Althaea officinalis L. } & 0 & in vitro & & & & & & & & & & & & & & & & & & & & & & & & & & & & & \\
\hline & 4 & in vivo + clinical & & & & & & & & & & & & & & & & $4^{5}$ & & & & & & & & & & & & & \\
\hline Camellia sinensis (L). & 0 & in vitro & & & & & & & & & & & & & & & & & & & & & & & & & & & & & \\
\hline & 2 & in vivo + clinical & $1^{6}$ & & & & & $1^{7}$ & & & & & & & $1^{8}$ & & & & & & & & & & & & & & & & \\
\hline Cetraria islandica (L.) & 0 & in vitro & & & & & & & & & & & & & & & & & & & & & & & & & & & & & \\
\hline & 1 & in vivo + clinical & & & & & & & & & & & & & & & & & & & & & & $1^{9}$ & & & & & & & \\
\hline Echinacea purpurea (L.) & 3 & in vitro & & & & & & & $2^{10}$ & & & & & & & & & & & & & & & $2^{11}$ & & & & & & & \\
\hline MOENCH & 8 & in vivo + clinical & $1^{12}$ & & & & & & $1^{13}$ & & $1^{14}$ & & & & & & & & & & $2^{15}$ & & $1^{16}$ & & & & & & $2^{1 /}$ & & $2^{18}$ \\
\hline Foeniculum vulgare (L.) & 2 & in vitro & & & & & & & & & & $2^{19}$ & & & & & & & & & & & & & & & & & & & \\
\hline & 0 & in vivo + clinical & & & & & & & & & & & & & & & & & & & & & & & & & & & & & \\
\hline Glycyrrhiza glabra L. & 1 & in vitro & & & & & & & $1^{20}$ & & & & & & & & & & & & & & & & & & & & & & \\
\hline & 2 & in vivo + clinical & & & & & & & & & & $1^{21}$ & & & & & & $1^{22}$ & & & & & & & & & & & & & \\
\hline Mentha x piperita $\mathrm{L}$. & 1 & in vitro & & & & & & & & & & $1^{23}$ & & & & & & & & & & & & & & & & & & & \\
\hline & 0 & in vivo + clinical & & & & & & & & & & & & & & & & & & & & & & & & & & & & & \\
\hline Pimpinella anisum $\mathrm{L}$. & 2 & in vitro & & & & & & & & & & $2^{24}$ & & & & & & & & & & & & & & & & & & & \\
\hline & 0 & in vivo + clinical & & & & & & & & & & & & & & & & & & & & & & & & & & & & & \\
\hline Plantago lanceolata L. & 1 & in vitro & & & & & & & & & & $1^{25}$ & & & & & & & & & & & & & & & & & & & \\
\hline & 0 & in vivo + clinical & & & & & & & & & & & & & & & & & & & & & & & & & & & & & \\
\hline Primula veris $\mathrm{L}$. & 1 & in vitro & $1^{26}$ & & & & & & & & & & & & & & & & & & & & & & & & & & & & \\
\hline & 0 & in vivo + clinical & & & & & & & & & & & & & & & & & & & & & & & & & & & & & \\
\hline Rubus fruticosus $\mathrm{L}$. & 0 & in vitro & & & & & & & & & & & & & & & & & & & & & & & & & & & & & \\
\hline & 1 & in vivo + clinical & & & & & & & & & & & & & & & & & & & & & & $1^{27}$ & & & & & & & \\
\hline Rumex ssp. L. & 2 & in vitro & $1^{28}$ & & & & & & $2^{29}$ & & & & & & & & & & & & & & & & & & & & & & \\
\hline & 0 & in vivo + clinical & & & & & & & & & & & & & & & & & & & & & & & & & & & & & \\
\hline
\end{tabular}


Table 4 Assessment ${ }^{\mathrm{a}}$ of medicinal plants based on peer-reviewed references ${ }^{\mathrm{b}}$ of the last 20 years aiming respiratory indications (Continued)

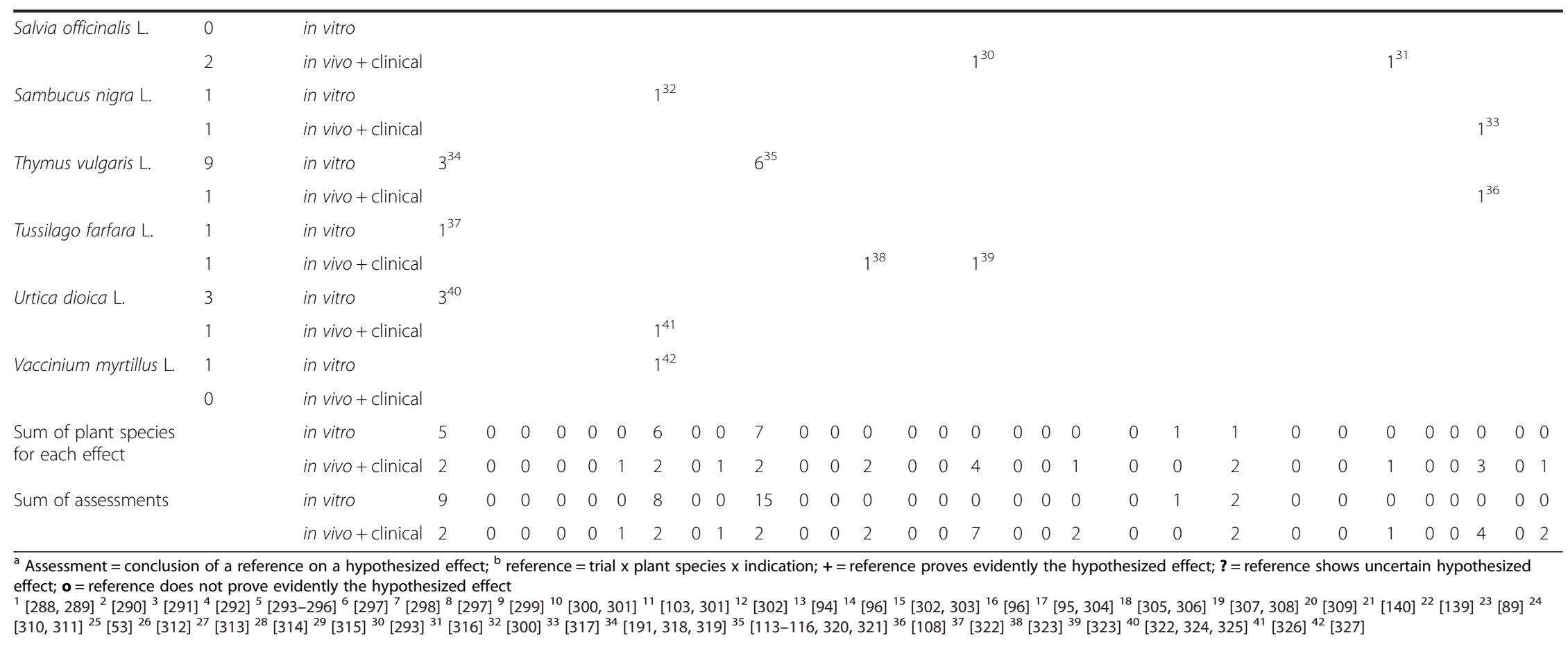


Table 5 Assessment ${ }^{a}$ of medicinal plants based on peer-reviewed references ${ }^{b}$ of the last 20 years aiming the modulation of the immune system and inflammation

\begin{tabular}{|c|c|c|c|c|c|c|c|c|c|c|c|c|c|c|}
\hline \multirow[t]{2}{*}{ Plant species } & \multirow[t]{2}{*}{ Number of references } & \multirow[t]{2}{*}{ Type of reference } & \multicolumn{3}{|c|}{ Immunostimulant } & \multicolumn{3}{|c|}{ Antiinflammatory } & \multicolumn{3}{|c|}{ Analgesic } & \multicolumn{3}{|c|}{ Hypothesis proved } \\
\hline & & & + & $?$ & o & + & $?$ & o & + & $?$ & $\overline{0}$ & + & $?$ & o \\
\hline \multirow[t]{2}{*}{ Achillea millefolium L. } & 2 & in vitro & & & & $2^{1}$ & & & & & & & & \\
\hline & 2 & in vivo + clinical & & & $1^{2}$ & & & $1^{3}$ & & & $1^{4}$ & & & \\
\hline \multirow[t]{2}{*}{ Agrimonia eupatoria L. } & 0 & in vitro & & & & & & & & & & & & \\
\hline & 1 & in vivo + clinical & & & & $1^{5}$ & & & & & & & & \\
\hline \multirow[t]{2}{*}{ Allium sativum $\mathrm{L}$. } & 4 & in vitro & $1^{6}$ & $1^{7}$ & & $2^{8}$ & & & & & & & & \\
\hline & 5 & in vivo + clinical & $5^{9}$ & & & $1^{10}$ & & & & & & & & \\
\hline \multirow[t]{2}{*}{ Camellia sinensis (L). KUNTZE } & 14 & in vitro & $3^{11}$ & & & $12^{12}$ & & & & & & & & \\
\hline & 5 & in vivo + clinical & $2^{13}$ & & & $2^{14}$ & & & $1^{15}$ & & & & & \\
\hline \multirow[t]{2}{*}{ Cetraria islandica (L.) ACH. } & 2 & in vitro & $2^{16}$ & & & & & & & & & & & \\
\hline & 1 & in vivo + clinical & & & & $1^{17}$ & & & & & & & & \\
\hline \multirow[t]{2}{*}{ Echinacea purpurea (L.) MOENCH } & 23 & in vitro & $16^{18}$ & $1^{19}$ & & $6^{20}$ & & & & & & & & \\
\hline & 13 & in vivo + clinical & $9^{21}$ & & $2^{22}$ & & & & & & & $1^{23}$ & & $1^{24}$ \\
\hline \multirow[t]{2}{*}{ Foeniculum vulgare (L.) MILL. } & 1 & in vitro & & & & $1^{25}$ & & & & & & & & \\
\hline & 3 & in vivo + clinical & & & & $1^{26}$ & & & $3^{27}$ & & & & & \\
\hline \multirow[t]{2}{*}{ Glycyrrhiza glabra L. } & 6 & in vitro & $4^{28}$ & & & $2^{29}$ & & & & & & & & \\
\hline & 4 & in vivo + clinical & $3^{30}$ & & & $1^{31}$ & & & $1^{32}$ & & & & & \\
\hline \multirow[t]{2}{*}{ Linum usita-tissimum $\mathrm{L}$. } & 1 & in vitro & & & & $1^{33}$ & & & & & & & & \\
\hline & 3 & in vivo + clinical & & $1^{34}$ & & $2^{35}$ & & & $1^{36}$ & & & & & \\
\hline \multirow[t]{2}{*}{ Malva sylvestris $\mathrm{L}$. } & 1 & in vitro & & & & $1^{37}$ & & & & & & & & \\
\hline & 3 & in vivo + clinical & $1^{38}$ & & & $2^{39}$ & & & $1^{40}$ & & & & & \\
\hline \multirow[t]{2}{*}{ Matricaria recutita $\mathrm{L}$. } & 5 & in vitro & & $1^{41}$ & & $4^{42}$ & & & & & & & & \\
\hline & 5 & in vivo + clinical & $1^{43}$ & & $1^{44}$ & $2^{45}$ & & & $2^{46}$ & & & & & \\
\hline \multirow[t]{2}{*}{ Mentha x piperita $\mathrm{L}$. } & 0 & in vitro & & & & & & & & & & & & \\
\hline & 1 & in vivo + clinical & & & & & & & $1^{47}$ & & & & & \\
\hline \multirow[t]{2}{*}{ Origanum vulgare L. } & 1 & in vitro & & & & $1^{48}$ & & & & & & & & \\
\hline & 6 & in vivo + clinical & $2^{49}$ & & & & & & $3^{50}$ & & & & $1^{51}$ & \\
\hline Pimpinella anisum L. & 1 & in vitro & & & & $1^{52}$ & & & & & & & & \\
\hline & 2 & in vivo + clinical & $1^{53}$ & $1^{54}$ & & & & & & & & & & \\
\hline Plantago lanceolata $\mathrm{L}$. & 3 & in vitro & & & & $3^{55}$ & & & & & & & & \\
\hline & 0 & in vivo + clinical & & & & & & & & & & & & \\
\hline Potentilla erecta (L.) RAEUSCH. & 1 & in vitro & & & & $1^{56}$ & & & & & & & & \\
\hline & 0 & in vivo + clinical & & & & & & & & & & & & \\
\hline Rubus fruticosus $\mathrm{L}$. & 4 & in vitro & & & & $4^{57}$ & & & & & & & & \\
\hline & 0 & in vivo + clinical & & & & & & & & & & & & \\
\hline Rumex ssp. L. & 1 & in vitro & & & & $1^{58}$ & & & & & & & & \\
\hline & 3 & in vivo + clinical & & & & $2^{59}$ & & & $2^{60}$ & & & & & \\
\hline Salix ssp. L. & 4 & in vitro & & & & $4^{61}$ & & & & & & & & \\
\hline & 1 & in vivo + clinical & & & & $1^{62}$ & & & & & & & & \\
\hline Salvia officinalis $\mathrm{L}$. & 0 & in vitro & & & & & & & & & & & & \\
\hline & 7 & in vivo + clinical & $1^{63}$ & $1^{64}$ & $1^{65}$ & $4^{66}$ & & & $2^{67}$ & & & & & \\
\hline Sambucus nigra L. & 2 & in vitro & $1^{68}$ & & & $1^{69}$ & & & & & & & & \\
\hline & 1 & in vivo + clinical & & & $1^{70}$ & & & & & & & & & \\
\hline
\end{tabular}


Table 5 Assessment ${ }^{\mathrm{a}}$ of medicinal plants based on peer-reviewed references ${ }^{\mathrm{b}}$ of the last 20 years aiming the modulation of the immune system and inflammation (Continued)

\begin{tabular}{|c|c|c|c|c|c|c|c|c|c|c|c|c|c|c|}
\hline \multirow[t]{2}{*}{ Thymus vulgaris $\mathrm{L}$. } & 5 & \multicolumn{4}{|l|}{ in vitro } & \multicolumn{9}{|l|}{$5^{71}$} \\
\hline & 4 & \multicolumn{2}{|l|}{ in vivo + clinical } & $1^{72}$ & $1^{73}$ & & & & \multicolumn{6}{|l|}{$2^{74}$} \\
\hline \multirow[t]{2}{*}{ Tussilago farfara $\mathrm{L}$. } & 1 & in vitro & & & & \multicolumn{9}{|l|}{$1^{75}$} \\
\hline & 0 & in vivo + clinical & & & & & & & & & & & & \\
\hline \multirow[t]{2}{*}{ Urtica dioica $\mathrm{L}$. } & 4 & In vitro & $2^{76}$ & & & $2^{77}$ & & & & & & & & \\
\hline & 4 & in vivo + clinical & $3^{78}$ & & & $1^{79}$ & & & \multicolumn{6}{|c|}{$1^{80}$} \\
\hline \multirow[t]{2}{*}{ Vaccinium myrtillus $\mathrm{L}$. } & 1 & In vitro & & & & $1^{81}$ & & & & & & & & \\
\hline & 2 & in vivo + clinical & $1^{82}$ & & & $2^{83}$ & & & & & & & & \\
\hline \multirow{2}{*}{\multicolumn{2}{|c|}{ Sum of plant species for each effect }} & in vitro & 6 & 3 & 0 & 20 & 0 & 0 & 0 & 0 & 0 & 0 & 0 & 0 \\
\hline & & in vivo + clinical & 9 & 4 & 6 & 13 & 0 & 1 & 12 & 0 & 1 & 1 & 1 & 1 \\
\hline \multirow{2}{*}{\multicolumn{2}{|c|}{ Sum of assessments }} & in vitro & 29 & 3 & 0 & 56 & 0 & 0 & 0 & 0 & 0 & 0 & 0 & 0 \\
\hline & & in vivo + clinical & 24 & 4 & 7 & 20 & 0 & 1 & 20 & 0 & 1 & 1 & 1 & 1 \\
\hline
\end{tabular}

${ }^{\mathrm{a}}$ Assessment $=$ conclusion of a reference on a hypothesized effect; ${ }^{b}$ reference $=$ trial $\mathrm{x}$ plant species $\mathrm{x}$ indication; $+=$ reference proves evidently the hypothesized effect; $?=$ reference shows uncertain hypothesized effect; $\mathbf{0}=$ reference does not prove evidently the hypothesized effect

$\left.\left.\left.{ }^{1}[328,329]^{2}[330]\right]^{3}[331]^{4}[331]{ }^{5}[332]{ }^{6}[333]^{7}[334]\right]^{8}[78,80]{ }^{9}[65,67,68,79,335]{ }^{10}[79]{ }^{11}[133,336,337]\right]^{12}[336,338-348]{ }^{13}[134,349]{ }^{14}[131,350]{ }^{15}[351]{ }^{16}[352$,

$\left.353]^{17}[354]^{18}[99,100,355-368]^{19}[369]^{20}[102,370-374]^{21}[93,97,98,375-380]^{22}[381,382]\right]^{23}[383]^{24}[384]^{25}[385]^{26}\left[3866{ }^{27}[386-388]\right.$ [ $28[144,334,389,390]$

$\left.{ }^{29}[391,392]{ }^{30}[138,380,393]{ }^{31}[394]\right]^{32}[394]{ }^{33}[395]{ }^{34}[396]{ }^{35}[397,398]{ }^{36}[397]{ }^{37}[399]{ }^{38}[400]{ }^{39}[401,402]{ }^{40}[401]{ }^{41}[403]{ }^{42}[404-407]{ }^{43}[408]{ }^{44}[409]{ }^{45}[410,411]$

$\left.\left.\left.\left.\left.{ }^{46}[410,412]{ }^{47}[413]{ }^{48}[414]^{49}[415,416]^{50}[417-419]{ }^{51}[420]{ }^{52}[421]\right]^{53}[422]{ }^{54}[423]\right]^{55}[392,424,425]\right]^{56}[426]{ }^{57}[427-430]\right]^{58}[431]{ }^{59}[432,433]{ }^{60}[432,434]\right]^{61}[426,435-$ $437]{ }^{62}[438]{ }^{63}[439]{ }^{64}[440]{ }^{65}[441]{ }^{66}[442-445]{ }^{67}[442,443]{ }^{68}[446]{ }^{69}[430]{ }^{70}[447]{ }^{71}[436,448-450]{ }^{72}[451]{ }^{73}[451]{ }^{74}[417,452]{ }^{75}[453]{ }^{76}[454,455]{ }^{77}[456,457]$

$\left.{ }^{78}[138,458,459]{ }^{79}[460]^{80}[460]{ }^{81}[344]\right]^{82}[461]{ }^{83}[461,462]$

risk of source selection bias, multiple types of sources were used initially: standard textbooks, peer-reviewed publications, a governmental report, and personal communications with experts. The risk of introducing database bias was reduced by using two different and independent databases and by using the Mesh Terms function of PubMed. The selection of the 30 traditionally used plant species may bear a sampling bias. European ethnoveterinary and traditional administrations of medicinal plants were screened to identify promising plant species for the bibliographic search. Due to our strategy, it is likely that frequently studied plant species come up as more promising compared to less frequently studied plants. Additionally, the timeliness of the review excluded studies published before 1994 which may be accepted in science for decades by e.g. the European Scientific Cooperative on Phytotherapy [55]. As a consequence, plants including Malva sylvestris L., Potentilla erecta (L.) RAEUSCH, Primula veris L., Quercus robur L. or Picea abies (L.) H.KARST. appeared less promising, although they are an integral element of traditional medicine.

\section{Comparison of traditional phytotherapy with up-to-date knowledge}

The most promising plant species of the peer-reviewed publications of the last 20 years were compared to the most common traditional administrations of the initial sources (Table 6). For the most promising plant species 62,30 and $27 \%$ are also frequently recommended in the initial sources for QA, QR and QL, respectively. The results confirmed the rationale of some traditional administrations of medicinal plants. Cases where the traditional applications were not confirmed by current studies, may be explained by the fact that only studies published between 1994 and 2014 were considered. Nevertheless, for many of these plant species broad scientific substantiation exists. For example, ESCOP monographs are available for Linum usitatissimum L., Pimpinella anisum L., Cetraria islandica (L.) ACH., Primula veris L. and Salix ssp..

\section{Complexity of varying chemistry}

It is important to consider that the amount of active constituents in plants depends on environmental factors. Based on the plant cultivars used climatic and geographic conditions, quality of the soil and method of cultivation and harvest influence the phytochemical composition of the plant and therefore, different amounts of constituents can be found in different batches. The used part of plant, widely divergent post-harvesting processing and methods of extraction and stabilization affect the chemistry of phytopharmaceuticals [56]. Environmental factors and post harvesting procedures are likely to explain varying effectiveness of a medicinal plant in different studies as reported for Echinacea [57, 58]. Therefore, a direct comparison of the outcome of the studies is difficult especially because of the lack of information regarding the phytochemical composition of the used test material. The use of pharmacopoeia quality in future research would ensure a defined amount of active constituents [59]. 
Table 6 Promising medicinal plants for treatment and prophylaxis of gastrointestinal and respiratory diseases and for modulation of the immune system and inflammation

\begin{tabular}{|c|c|c|}
\hline Indication & $\begin{array}{l}\text { Traditional applications in initial sources }{ }^{1} \text { (number } \\
\text { of references recommending the plant for the indication) }\end{array}$ & $\begin{array}{l}\text { Peer-reviewed references } \\
\left.\text { (sum of points gathered in the scoring system }{ }^{2}\right)^{b}\end{array}$ \\
\hline \multirow[t]{14}{*}{ Gastrointestinal tract } & Matricaria recutita L. (7) & Allium sativum L. (41) \\
\hline & Foeniculum vulgare (L.) MILL. (6) & Mentha x piperita L. (30) \\
\hline & Potentilla erecta (L.) RAEUSCH (5) & Salvia officinalis L. (27) \\
\hline & Linum usitatissimum L. (5) & Origanum vulgare L. (24) \\
\hline & Rubus fruticosus L. (5) & Camellia sinensis (L.) KUNTZE (18) \\
\hline & Thymus vulgaris L. (4) & Matricaria recutita L. (15) \\
\hline & Quercus robur L. (4) & Glycyrrhiza glabra L. (14) \\
\hline & Mentha x piperita L. (4) & Thymus vulgaris L. (13) \\
\hline & Urtica dioica L. (4) & Foeniculum vulgare (L.) MILL. (7) \\
\hline & Vaccinium myrtillus L. (4) & Carum carvi L. (6) \\
\hline & Salvia officinalis L. (4) & Pimpinella anisum L. (6) \\
\hline & Carum carvi L. (4) & Rumex sp. L. (6) \\
\hline & Camellia sinensis (L.) KUNTZE (4) & Urtica dioica L. (6) \\
\hline & Achillea millefolium L. (4) & \\
\hline \multirow[t]{10}{*}{ Respiratory tract } & Thymus vulgaris L. (7) & Echinacea purpurea (L.) MOENCH (10) \\
\hline & Pimpinella anisum L. (6) & Thymus vulgaris L. (10) \\
\hline & Althaea officinalis L. (5) & Althaea officinalis L. (8) \\
\hline & Cetraria islandica (L.) ACH. (5) & Glycyrrhiza glabra L. (5) \\
\hline & Primula veris L. (5) & Salvia officinalis L. (5) \\
\hline & Foeniculum vulgare (L.) MILL. (4) & Tussilago farfara L. (5) \\
\hline & Sambucus nigra L. (4) & Urtica dioica L. (5) \\
\hline & Malva sylvestris L. (4) & Achillea millefolium L. (4) \\
\hline & Allium sativum L. (4) & Camellia sinensis (L.) KUNTZE (4) \\
\hline & Picea abies (L.) H.KARST. (4) & Sambucus nigra L. (4) \\
\hline \multirow{12}{*}{$\begin{array}{l}\text { Modulation of immune } \\
\text { system and inflammation }\end{array}$} & Echinacea purpurea (L.) MOENCH (2) & Echinacea purpurea (L.) MOENCH (41) \\
\hline & Salix sp. L. (2) & Camellia sinensis (L.) KUNTZE (26) \\
\hline & Thymus vulgaris L. (1) & Glycyrrhiza glabra L. (19) \\
\hline & Sambucus nigra L. (1) & Origanum vulgare L. (19) \\
\hline & Urtica dioica L. (1) & Allium sativum L. (18) \\
\hline & Malva sylvestris L. (1) & Salvia officinalis L. (16) \\
\hline & Plantago lanceolata L. (1) & Urtica dioica L. (15) \\
\hline & Allium sativum L. (1) & Foeniculum vulgare (L.) MILL. (11) \\
\hline & Tilia cordata MILL/Tilia platyphyllos SCOP. (1) & Matricaria recutita L. (11) \\
\hline & Artemisia absynthum L. (1) & Malva sylvestris L. (9) \\
\hline & Verbascum sp. L. (1) & Rumex sp. L. (9) \\
\hline & Armoracia rusticana PH. GÄRTN.(1) & \\
\hline
\end{tabular}

\footnotetext{
${ }^{1}$ initial sources = standard literature, based on traditional empiric knowledge and historical literature of veterinary [42-45], and human phytotherapy [46], peer-reviewed publications of European [47] and Swiss ethnoveterinary medicine [36, 38] and a report of the European Food Safety Authority (EFSA) [48] focusing on the use of plants as feed additives in animal production; ${ }^{2}$ Score $=3 \times$ (number of proven effects in clinical studies - number disproof of effects in clinical studies) $+2 \times$ (number of proven effects in in vivo studies - number of disproof of effects in in vivo studies) $+1 \times$ (number of proven effects in in vitro studies - number of disproof of effects of in vitro studies) ${ }^{a}$ gastrointestinal tract' all plant species recommended for QA 4 times or more in the initial sources, ordered by incidence of recommendation by different authors as listed in detail in Additional file 2; ${ }^{\text {a }}$ respiratory tract: all plant species recommended for QR 4 times or more in the initial sources, ordered by incidence of recommendation by different authors as listed in detail in Additional file 2; ${ }^{a}$ Modulation of immune system and inflammation: includes all plant species recommended for QL 1 time or more in the initial sources, ordered by incidence of recommendation by different authors as presented in file 2 in greater detail; ${ }^{b}$ gastrointestinal tract: includes all plant species gathered for QA with a minimum score of 6 ordered by sum of points the plant species gathered; ${ }^{b}$ respiratory tract: includes all plant species gathered for QR with a minimum score of 4 , ordered by sum of points the plant species gathered; ${ }^{b}$ Modulation of immune system and inflammation: includes all plant species gathered for QL with a minimum score of 9, ordered by sum of points the plant species gathered; bold letters = plant species recommended in initial sources and in peer-reviewed references for same indication
} 


\section{Relevance for the treatment of livestock diseases}

From the 418 references assessed, 46 focused on livestock including 19 clinical references for pigs and five for cattle. Most of these clinical studies used the plants as a feed additive and not as a pharmaceutical. This might be due to complex regulatory affairs exacerbating the licensing and authorization of a medicinal plant or a plant extract as a veterinary drug.

Due to missing information regarding the absorption of orally administered medicinal plant compounds by the gastrointestinal tract, local treatment of gastrointestinal diseases might promising compared to a systemic treatment of respiratory diseases. Effective concentrations of, e.g. essential oils via inhalation may be obtained in the respiratory tract, but it is less practicable when larger herds need to be treated. While pigs as monogastrics might be compared with humans, calves are young ruminants and the biotransformation of plants secondary metabolites in the forestomach is not well known. However, in suckling calves plant extracts can be administered by daily milk diet to ensure bypassing the forestomach by oesophagal groove reflex.

We identified only a few recent references and also few traditional recommendations for the indication $Q R$ $(n=57)$ compared to QA $(n=198)$. Interestingly, similar findings were reported from ethnoveterinary research $[47,60]$. One explanation might include the challenge of the treatment of respiratory diseases because systemic effects are needed to obtain the therapeutic effect compared to primarily local effects. Modulation of the immature or deficient immune system of calves and piglets provides a starting-point for the prevention of multifactorial infectious diseases. In the traditional phytotherapy literature, effects of medicinal plants on the immune system cannot be found frequently. This might be explained by the fact that immunology is a relatively young scientific field that developed rapidly in recent years. In human medicine, some immune stimulating preparations are already available on the market and therefore, a variety of studies is available. In contrast, for livestock, scientific knowledge is not transferred to practical use yet.

This review mainly focused on therapeutic options of medicinal plants. From this point of view, the relevance of possible toxicity, adverse effects or residues in livestock products remains open. Regarding safety aspects Tussilago farfara L. cannot be recommended as a therapeutic medicinal plant due to the presence of toxic pyrrolizidine alkaloids. Nevertheless, the majority of plant species in this review are consumed by humans as food, spices, luxury foodstuffs or as registered nutraceuticals and pharmaceuticals. If these plant species are safe for ingestion in humans, it might be legitimate to transfer these results to other mammalians with a comparable metabolism (herbivores and omnivores). Under these circumstances, risks for humans based on residues in products from food-producing animals should be neglectable. For herbivores and omnivores with a mainly plantbased ration, safety of the most medicinal plant species can be supposed. These species may cope with plant secondary metabolites in a similar way as humans [35].

\section{Promising plant species for gastrointestinal and respiratory diseases and for modulation of the immune system and inflammation}

Several trials show the equivalence of plant-derived pharmaceuticals with synthetic ones, but nonetheless there are some trials showing the contrary. Based on the data presented in this review, Allium sativum L., Mentha x piperita L. and Salvia officinalis L. carry a high potential for treatment of gastrointestinal diseases (Table 3). Echinacea purpurea (L.) MOENCH, Thymus vulgaris L. and Althaea officinalis L. may be considered for the treatment of respiratory diseases (Table 4). Regarding the majority of positive results of studies evaluated, Echinacea purpurea (L.) MOENCH, Camellia sinensis (L.) KUNTZE and Glycyrrhiza glabra L. were found to stimulate the immune response (Table 5).

Traditionally, plant species with a high content of tanning agents are administered in diarrhea. Allium sativum L. does not contain tanning agents, but due to its antibacterial, antidiarrheal, anti-inflammatory and immunomodulatory effects, it may be used for prophylactic and acute treatment in diarrhea of calves and piglets. Eight in vivo and clinical studies were identified for Allium sativum L. proving these effects, and no studies disproving them. A trial conducted with neonatal calves showed that allicin, a main active compound of Allium sativum L., delayed the onset of diarrhea due to Cryptosporidium parvum [61]. Two clinical studies demonstrated antidiarrheal effects and a reduction of the fecal coliform count by Allium sativum L. There is also evidence for an improvement of performance in pre-ruminant calves [62,63]. The immunomodulatory activity of Allium sativum L. in pigs $[64,65]$ and poultry $[66,67]$ may hold true in immunocompromised calves to support their immune defense. Its antibacterial effects on Escherichia coli and Salmonella ssp. in vitro suggest a high probability of antibacterial activity in vivo [68-75]. Nevertheless, more clinical studies are necessary to investigate antiinfective effects of Allium sativum L. in young farm animals. Allium sativum L. has been reported to exhibit antiinflammatory activity in rats [76]. There is also mechanistic evidence for anti-inflammatory properties as well as immunostimulation showed in three in vitro studies, namely an inhibition of leucocyte migration [77], modulation of interleukin and interferon-gamma expression [78] and a suppression of nitrogen oxide production in macrophages [79]. An anti-inflammatory effect may be useful for the treatment of systemic inflammation 
processes often accompanied with diarrhea. Facing animal welfare and regarding efficient synthetic non-steroidal and steroidal anti-inflammatory agents, it is debatable whether there is a need for plant-derived alternatives. While synthetic non-steroidal and steroidal anti-inflammatory agents often produce considerable adverse effects including an inhibition of mucus production [80, 81], medicinal plants compass considerable adverse-effects because they contain several different active compounds which might reduce the potential of unwanted effects [82]. In in vivo tests for acute and chronic toxicity, the maximum tolerance dose and genotoxicity Allium sativum L. was demonstrated to be relatively safe if administered in therapeutic dosages [83] and if estimated for the animals metabolic body weight [84]. With respect to food quality, it must be assured that residues of Allium sativum L., responsible for the typical taste of this plant do not result in an altered taste of meat.

To reduce enteral spasm during diarrheal diseases, Mentha $x$ piperita L. might be an efficient treatment option based on three clinical studies in humans, demonstrating efficient spasmolytic activity comparable to butylscopolamine [85-87]. The underlying mechanism includes inhibition of smooth muscle contractility through the block of calcium influx by menthol [88]. In traditional medicine, Mentha $x$ piperita L. has been used in the therapy of respiratory diseases. Peppermint essential oil showed spasmolytic activity on rat trachea ex vivo [89]. But there are no clinical studies in veterinary medicine for Mentha x piper$i t a \mathrm{~L}$. in respiratory disease. No adverse effects have been reported for Mentha $x$ piperita $\mathrm{L}$. infusions or oral intake of leaves [90]. Excessive inhalation or local application of pure Mentha $x$ piperita L. essential oil was shown to lead to hypersensitivity reactions [56]. Contraindications are severe hepatic damage and cholestasis [43].

Based on this review, the most prominent plant species for stimulation of the immune system is Echinacea purpurea (L.) MOENCH. The main constituents are polysaccharides, alkylamides, caffeic acid esters and polyacetylenes [91]. It has been used in therapy for stimulation of the immune system in human medicine, mainly for prevention of viral infections of the respiratory tract [92]. A total of 23 clinical and in vivo studies revealed multiple effects on the innate and acquired immune system. Echinacea purpurea (L.) MOENCH was shown to increase the immune response towards swine erysipelas vaccination in piglets [93], prevented enveloped virus infections in humans [94] and reduced symptom severity in naturally acquired upper respiratory tract infections in humans [95]. In contrast, seven clinical or in vivo studies reported the absence of the above mentioned effects. For example Echinacea purpurea (L.) MOENCH failed to enhance growth or to show any immunomodulatory effect in one study in pigs [96]. Reasons for these negative results may be due to a very small number of individuals, an improper dosage or study design. As mentioned above, the diversity of non-standardized Echinacea preparations with varying chemistry is likely to result in different findings. In some studies, the dosage was not reported, and therefore it was not possible to estimate how much plant material or drug equivalent was administered per day. Consequently, due to missing data final conclusions cannot be drawn. Nevertheless, eight in vivo studies reported modulations of immune system and blood cell count, and no studies were found disproving these effects. Different Echinacea species were found to increase the total number of white and red blood cells in mice [97] and horses [98]. Twenty-six in vitro studies demonstrated the underlying mechanisms of immunomodulatory effects of Echinacea purpurea (L.) MOENCH. It was reported to activate macrophages and natural killer cells [99-101] and to modulate several cytokines [102-105]. Echinacea purpurea (L.) MOENCH is known as a safe immunostimulant in humans and several products are available on the market. No reported interactions with other drugs and no toxic effects after overdosage were reported [106]. Possible rare adverse effects such as hypersensitivity reactions are reported, but no adverse effects have been observed during longterm administration [107]. In general, Echinacea purpurea (L.) MOENCH seems to be effective in preventing respiratory diseases and as an early intervention immediately after onset of first symptoms of infectious diseases [95]. However, further veterinary clinical studies need to be performed, especially to evaluate effective dosages.

In human medicine, Thymus vulgaris L. has been already effectively used according to its antitussive and mucolytic effects in the treatment of acute bronchitis, often in combinations with other plant species, e. g. Primula veris $\mathrm{L}$. for its expectorant effects [108-110]. The main active compound of Thymus vulgaris $\mathrm{L}$. is the essential oil containing thymol, geraniol, thujanol and linalool [111]. The above mentioned effects still have to be investigated for veterinary purposes. Nevertheless, an enhancement of the mucociliary clearance in mice was shown in two in vivo studies [112, 113]. This effect was explained by an interaction with beta ${ }_{2}$ receptors in rat lung tissue [112]. Additionally, three ex vivo studies demonstrated spasmolytic effects of Thymus vulgaris L. on tracheal chains comparable to theophylline [114-116]. The reported antiinflammatory properties [117] and antibacterial effects found in in vitro studies [118-120] of Thymus vulgaris L. still needs to be investigated in clinical studies. In vivo studies on the toxicology of Thymus vulgaris L. leaf extract showed no toxic potential $[121,122]$. In summary, the data available support the potential for using Thymus vulgaris L. for treatment of respiratory diseases in livestock.

Camellia sinensis (L.) KUNTZE seems to be useful for treatment of diarrhea as well as for stimulation of the immune system. Main constituents are polyphenolic compounds (up to $25 \%$ catechin derivatives in non-fermented 
plants, e.g. epigallocatechin), purine alkaloids (caffeine, theobromine, theophylline) and flavonoids [123]. Some clinical studies reported beneficial effects of Camellia sinensis (L.) KUNTZE on gut health as indicated by a reduced prevalence of postweaning diarrhea in piglets, but also a decrease in growth performance [124]. An experimental trial on a diet with Camellia sinensis (L.) KUNTZE whole plant extract revealed a significant decrease of Clostridia counts, but also of Enterococci counts in the feces of piglets compared to a standard diet with antibiotics [125]. Two in vivo studies showed also anti-influenza virus activity in mice [126] and chicken [127], which might be due to an inhibition of virus adsorption [126]. Fifteen in vitro and five in vivo studies demonstrated antioxidative [128-130] and antiinflammatory $[131,132]$ effects and a modulation of the immune system [133, 134]. No studies were found disproving these effects. In mice, the intake of a concentrated extract of Camellia sinensis (L.) KUNTZE did not lead to unwanted adverse effects [135]. Despite that Camellia sinensis (L.) KUNTZE is known to be fairly devoid of unwanted effects, some reports on liver damage related to the intake of Camellia sinensis (L.) KUNTZE extract are available [136, 137]. In summary, most reports state that safety of Camellia sinensis (L.) KUNTZE extract can be supposed, if used appropriately to the recommendations [136]. Therefore, Camellia sinensis (L.) KUNTZE bears a reliable potential for prophylaxis and therapy of diseases in calves and piglets.

The main active compound of medicinally used roots of Glycyrrhiza glabra L. is the saponin glycyrrhizin. Furthermore, it contains flavonoids and isoflavonoids, chalcones, cumarins and phytosterols [123]. With regard to the inclusion criteria of this review, no clinical studies focusing on Glycyrrhiza glabra L. could be found. Nevertheless, it was shown to exhibit immunostimulatory effects in vivo, by stimulation of cellular and nonspecific response [138]. In three in vivo and ex vivo models, antitussive [139] and tracheal smooth muscle relaxing activity [140] as well as regulating effects in the gastrointestinal tract were reported [141]. Four in vitro studies demonstrated its antimicrobial $[142,143]$ and antiviral potential by activation of autophagy [144]. In an assessment of different plant species, Glycyrrhiza glabra L. exerted the strongest antiviral activity against rotavirus [145]. Due to these versatile effects, Glycyrrhiza glabra L. might be beneficial for prophylaxis and treatment of virus induced diseases of the respiratory- as well as the gastrointestinal tract. Regarding the safety of Glycyrrhiza glabra L., it is important to choose the right dosage due to the hyper-mineralocorticoid-like effects of glycyrrhizin. An acceptable daily dosage of $0.015-0.229 \mathrm{mg}$ glycyrrhizin $/ \mathrm{kg}$ body weight/day for human and animals was reported [146].

\section{Conclusions}

This systematic review identified common medicinal plant species as a potential future therapeutic option for gastrointestinal and respiratory diseases in calves and piglets. Based on their plant specific multi-component compositions, the versatile effects of medicinal plants as 'multi-target drugs' may bear a potential for the treatment of respiratory and gastrointestinal diseases in calves and piglets. Medicinal plants are unlikely to replace chemical medications as a general rule, but they may be a single or at least a complementary treatment. In concert with housing, feeding and hygiene, medicinal plants are part of a sustainable, natural option for improving animal health and reducing the use of antimicrobials in livestock farming. The results of this review provide support for a need for additional in vitro, in vivo and clinical research focused on phytotherapy for recently emerging and challenging diseases in livestock. While a large amount of peerreviewed studies about medicinal plant species is available, most of the clinical and experimental studies were performed in humans and experimental animals. More research is needed to evaluate the potential of medicinal plants for treatment of farm animals. The data from this review provide guidance on medicinal plants promising for further investigations in livestock: the most promising candidates for gastrointestinal diseases are Allium sativum L., Mentha $x$ piperita L. and Salvia officinalis L.; for diseases of the respiratory tract, Echinacea purpurea (L.) MOENCH, Thymus vulgaris L. and Althea officinalis L. were found most promising, and Echinacea purpurea (L.) MOENCH, Camellia sinensis (L.) KUNTZE, Glycyrrhiza glabra L. and Origanum vulgare L. were identified as best candidates for modulation of the immune system and inflammation. Based on this review, studies are under way to investigate the effects of promising medicinal plants in calves and piglets.

\section{Additional files}

Additional file 1: Protocol of the systematic review. (DOCX $27 \mathrm{~kb}$ )

Additional file 2: Plant species recommended for the treatment of gastrointestinal and respiratory diseases in human and animals based on standard textbooks, European peer-reviewed ethnoveterinary publications and an EFSA report. (XLSX $42 \mathrm{~kb}$ )

Additional file 3: Assessment of medicinal plants effects in 418 final peer-reviewed references. (XLSX $59 \mathrm{~kb}$ )

\section{Abbreviations}

ATCvet, Anatomical Therapeutic Chemical classification system for veterinary medicine; e.g., exempli gratia (in English: for example); EFSA, European Food Safety Authority; EMA, European Medicines Agency; ESCOP, European Scientific Cooperative On Phytotherapy; MBW, metabolic body weight; $\mathrm{pH}$, pondus Hydrogenii; PICOS, population, intervention, comparator, outcome, study design; QA, preparations used for the treatment of diseases affecting the alimentary tract or metabolism, particularly unspecified or infectious diarrhea and intestinal spasms; QL, immunomodulating agents; QR, preparations for the treatment of diseases in the respiratory system; sp., any species, not specified in detail; ssp., subspecies; WHO, World Health Organization 


\section{Acknowledgements}

We want to thank the specialists of veterinary phytotherapy for reviewing the primary list of 29 medicinal plant species, namely Dr. med. vet. Caecilia Brendieck-Worm, Dr. med. vet. Werner Hagmueller and Dr. med. vet. Elisabeth Stoeger. Furthermore, we want to thank Edith Hofer, librarian of the Vetsuisse library, University of Bern, for the continuous and straightforward support; Dr. Stephan Haesler, president of the Swiss Association of the History of Veterinary Medicine, for providing historic veterinary literature and Dr. Christopher Portier for linguistic revision. Special thanks goes to the Swiss retailer Migros for funding this work.

\section{Funding}

This work was funded by the Swiss retailer Migros (project \#500 54). The funding institution were not involved in the study design, collection, analysis and interpretation of the obtained data and in writing the manuscript.

\section{Availability of data and materials}

All the data supporting the findings are contained within the manuscript and in the Additional files 1, 2 and 3.

\section{Authors' contributions}

HA designed the review, collected, analysed and interpreted the data and wrote the manuscript. MMev participated in the design of the study, in the interpretation and discussion of data and coordinated the writing and reviewing of the manuscript. MK contributed his expert-knowledge on diseases of calves and participated in the interpretation and discussion of data. HN and NG contributed their expert-knowledge on diseases of piglets and participated in the interpretation and discussion of data. MMel contributed his expert-knowledge on pharmaceutical biology and participated in the interpretation and discussion of data. MW participated in the design of the study, in the interpretation and discussion of data and in the writing of the manuscript. All authors read and approved the final manuscript.

\section{Competing interests}

The authors declare that they have no competing interests'.

\section{Consent for publication}

Not applicable because this manuscript does not contain any individual persons' data.

\section{Ethics approval and consent to participate}

Not applicable for this systematic literature review.

\section{Author details \\ 'Department of Livestock Sciences, Research Institute of Organic Agriculture (FiBL), Ackerstrasse 113, postbox 219, Frick 5070, Switzerland. 'Division Veterinary Pharmacology \& Toxicology, Department Clinical Research and Veterinary Public Health, Vetsuisse Faculty, University of Bern, Laenggassstrasse 124, Bern 3012, Switzerland. ${ }^{3}$ Department of Farm Animals, Vetsuisse Faculty, University of Zurich, Winterthurerstrasse 260, Zurich 8057, Switzerland. ${ }^{4}$ Department of Clinical Veterinary Medicine, Swine Clinic, Vetsuisse Faculty, University of Bern, Bremgartenstrasse 109a, Bern 3012, Switzerland. ${ }^{5}$ Dahlem Centre of Plant Sciences, Institute of Pharmacy, Freie Universität Berlin, Koenigin-Luise-Strasse $2+4$, Berlin 14195, Germany.}

\section{Received: 27 November 2015 Accepted: 30 May 2016}

\section{Published online: 06 June 2016}

\section{References}

1. Donovan GA, Dohoo IR, Montgomery DM, Bennett FL. Associations between passive immunity and morbidity and mortality in dairy heifers in Florida, USA. Prev Vet Med. 1998;34(1):31-46.

2. Meganck V, Hoflack G, Opsomer G. Advances in prevention and therapy of neonatal dairy calf diarrhoea: a systematical review with emphasis on colostrum management and fluid therapy. Acta Vet Scand. 2014;56:75.

3. Cusack PM, McMeniman N, Lean IJ. The medicine and epidemiology of bovine respiratory disease in feedlots. Aust Vet J. 2003:81(8):480-7.

4. Taylor JD, Fulton RW, Lehenbauer TW, Step DL, Confer AW. The epidemiology of bovine respiratory disease: what is the evidence for preventive measures? Can Vet J. 2010;51(12):1351-9.
5. Taylor JD, Fulton RW, Lehenbauer TW, Step DL, Confer AW. The epidemiology of bovine respiratory disease: What is the evidence for predisposing factors? Can Vet J. 2010;51(10):1095-102.

6. Fairbrother JM, Nadeau E, Gyles CL. Escherichia coli in postweaning diarrhea in pigs: an update on bacterial types, pathogenesis, and prevention strategies. Anim Health Res Rev. 2005;6(1):17-39.

7. Windeyer MC, Leslie KE, Godden SM, Hodgins DC, Lissemore KD, LeBlanc SJ. Factors associated with morbidity, mortality, and growth of dairy heifer calves up to 3 months of age. Prev Vet Med. 2014;113(2):231-40.

8. Lorenz I, Fagan J, More SJ. Calf health from birth to weaning. II. Management of diarrhoea in pre-weaned calves. Ir Vet J. 2011;64(1):9.

9. Lorenz I, Earley B, Gilmore J, Hogan I, Kennedy E, More SJ. Calf health from birth to weaning. III. housing and management of calf pneumonia. Ir Vet J. 2011;64(1):14.

10. Cho YI, Yoon KJ. An overview of calf diarrhea - infectious etiology, diagnosis, and intervention. J Vet Sci. 2014;15(1):1-17.

11. Bartels CJ, Holzhauer M, Jorritsma R, Swart WA, Lam TJ. Prevalence, prediction and risk factors of enteropathogens in normal and non-normal faeces of young Dutch dairy calves. Prev Vet Med. 2010;93(2-3):162-9.

12. Uhde FL, Kaufmann T, Sager H, Albini S, Zanoni R, Schelling E, Meylan M. Prevalence of four enteropathogens in the faeces of young diarrhoeic dairy calves in Switzerland. Vet Rec. 2008;163(12):362-6.

13. Luginbühl A, Reitt K, Metzler A, Kollbrunner M, Corboz L, Deplazes P. Field study of the prevalence and diagnosis of diarrhea-causing agents in the newborn calf in a Swiss veterinary practice area. Schweiz Arch Tierheilkd. 2005;147(6):245-52.

14. Kaske M, Leister T, Smolka K, Andresen U, Kunz H-J, Kehler W, Schuberth HJ, Koch A. Neonatal diarrhea in the calf - IV. communication: Neonatal diarrhea as a herd problem: colostrum management. Praktischer Tierarzt. 2009;90(8):756-67.

15. Thomson JR, Friendship RM. Digestive System. In: Zimmerman JJ, Karriker LA, Ramirez A, Schwartz KJ, Stevenson GW, editors. Disease of Swine. 10th ed. John Wiley \& Sons; 2012.

16. Frydendahl K. Prevalence of serogroups and virulence genes in Escherichia coli associated with postweaning diarrhoea and edema disease in pigs and a comparison of diagnostic approaches. Vet Microbiol. 2002;85(2):169-82.

17. Fairbrother JM, Gyles CL: Colibacillosis. In: Diseases Of Swine. 10 edn. Edited by Zimmerman JJ, Karriker LA, Ramirez A, Schwartz KJ, Stevenson GW. Ames, Chichester, Oxford: John Wiley \& Sons; 2012.

18. Rossi L, Dell'Orto V, Vagni S, Sala V, Reggi S, Baldi A. Protective effect of oral administration of transgenic tobacco seeds against verocytotoxic Escherichia coli strain in piglets. Vet Res Commun. 2014;38(1):39-49.

19. Madec F, Bridoux N, Bounaix S, Jestin A. Measurement of digestive disorders in the piglet at weaning and related risk factors. Prev Vet Med. 1998;35(1):53-72.

20. Laine TM, Lyytikainen T, Yliaho M, Anttila M. Risk factors for post-weaning diarrhoea on piglet producing farms in Finland. Acta Vet Scand. 2008;50:21.

21. Rossi L, Vagni S, Polidori C, Alborali GL, Baldi A, Dell'Orto V. Experimental Induction of Escherichia coli Diarrhoea in Weaned Piglets. Open J Vet Med. 2012;2:1-8.

22. VanAlstine WG: Respiratory System. In: Diseases of Swine. 10 edn. Edited by Zimmerman JJ, Karriker LA, Ramirez A, Schwartz KJ, Stevenson GW. Ames, Chichester, Oxford: John Wiley \& Sons, Inc:; 2012.

23. Hilton WM. BRD in 2014: where have we been, where are we now, and where do we want to go? Anim Health Res Rev. 2014;15(2):120-2.

24. Bähler C, Steiner A, Luginbuhl A, Ewy A, Posthaus H, Strabel D, Kaufmann T, Regula G. Risk factors for death and unwanted early slaughter in Swiss veal calves kept at a specific animal welfare standard. Res Vet Sci. 2012;92(1):162-8.

25. Stöber M. Enzootische Bronchopneumonie. In: Dirksen G, Gründer H-D, Stöber M, editors. Innere Medizin und Chirurgie des Rindes. 4th ed. Berlin: Parey Buchverlag; 2002. p. 310-3.

26. Kaske M, Kunz H-J, Reinhold P. Die enzootische Bronchopneumonie des Kalbes - ein Update. Praktischer Tierarzt. 2012;93:232-45.

27. Hansen MS, Pors SE, Jensen HE, Bille-Hansen V, Bisgaard M, Flachs EM, Nielsen $\mathrm{OL}$. An investigation of the pathology and pathogens associated with porcine respiratory disease complex in Denmark. J Comp Pathol. 2010;143(2-3):120-31.

28. Harms PA, Halbur PG, Sorden SD. Three cases of porcine respiratory disease complex associated with porcine circovirus type 2 infection. J Swine Health Prod. 2002;10(1):27-30

29. Choi YK, Goyal SM, Joo HS. Retrospective analysis of etiologic agents associated with respiratory diseases in pigs. Can Vet J. 2003;44(9):735-7.

30. Beer G, Doherr MG, Bähler C, Meylan M. Antibiotikaeinsatz in der Schweizer Kälbermast. Schweiz Arch Tierheilkd. 2015;157(1):55-7. 
31. Pendl W, Jenny B, Sidler X, Spring P. Antibiotikaeinsatz beim Schwein: Erste Resultate aus dem Projekt FitPig. In: Kreuzer M, Lanzini T, Liesegang A Bruckmaier R, Hess HD, editors. Gesunde und leistungsfähige Nutztiere: Futter an Genotyp oder Genotyp an Futter anpassen? vol. 38. Zürich: ETH-Schriftenreihe zur Tierernährung; 2015.

32. Eidgenössisches Departement des Innern, EDI, Bundesamt für Lebensmittelsicherheit und Veterinärwesen, BLV. ARCH Bericht über den Vertrieb von Antibiotika in der Veterinärmedizin und das Antibiotikaresistenzmonitoring bei Nutztieren in der Schweiz. 2013

33. Williamson EM. Synergy and other interactions in phytomedicines. Phytomedicine. 2001;8(5):401-9.

34. Wagner H, Ulrich-Merzenich $\mathrm{G}$. Synergy research: approaching a new generation of phytopharmaceuticals. Phytomedicine. 2009;16(2-3):97-110.

35. Reichling J, Saller R. Herbal remedies in veterinary phytotherapy. Schweiz Arch Tierheilkd. 2001;143(8):395-403.

36. Disler M, Ivemeyer S, Hamburger M, Vogl CR, Tesic A, Klarer F, Meier B, Walkenhorst M. Ethnoveterinary herbal remedies used by farmers in fou north-eastern Swiss cantons (St. Gallen, Thurgau, Appenzell Innerrhoden and Appenzell Ausserrhoden). J Ethnobiol Ethnomed. 2014;10:32.

37. Mayer M, Vogl CR, Amorena M, Hamburger M, Walkenhorst M. Treatment of organic livestock with medicinal plants: a systematic review of European ethnoveterinary research. Forschende Komplementärmedizin 2014;21(6): 375-86.

38. Schmid K, Ivemeyer S, Vogl C, Klarer F, Meier B, Hamburger M, Walkenhorst M. Traditional use of herbal remedies in livestock by farmers in 3 Swiss cantons (Aargau, Zurich, Schaffhausen). Forsch Komplementmed. 2012;19(3):125-36.

39. Liberati A, Altman DG, Tetzlaff J, Mulrow C, Gøtzsche PC, loannidis JPA, Clarke M, Devereaux PJ, Kleijnen J, Moher D. The PRISMA Statement for Reporting Systematic Reviews and Meta-Analyses of Studies That Evaluate Health Care Interventions: Explanation and Elaboration. PLoS Med. 2009;6(7):e1000100.

40. Moher D, Liberati A, Tetzlaff J, Altman DG. Preferred Reporting Items for Systematic Reviews and Meta-Analyses: The PRISMA Statement. J Clin Epidemiol. 2009;62(10):1006-12.

41. Shea BJ, Grimshaw JM, Wells GA, Boers M, Andersson N, Hamel C, Porter AC, Tugwell P, Moher D, Bouter LM. Development of AMSTAR: a measurement tool to assess the methodological quality of systematic reviews. BMC Med Res Methodol. 2007;7:10.

42. Wynn SG, Fougère BJ. Veterinary herbal medicine. 1st ed. St. Louis: Mosby Elsevier; 2007.

43. Reichling J, Gachnian-Mirtscheva R, Frater-Schröder M, Saller R, Rabinovich MI, Widmaier W. Heilpflanzenkunde für die Veterinärpraxis. 2nd ed. Berlin Heidelberg: Springer Verlag; 2008

44. Aichberger L, Graftschafter M, Fritsch F, Gansinger D, Hagmüller W, HahnRamssl I, Hozzank A, Kolar V, Stöger E: Kräuter für Nutz- und Heimtiere, 2 edn. Wien: Eigenverlag Arbeitsgruppe Kräuter und Gewürze für Nutz- und Heimtiere; 2012

45. Klarer F, Stöger E, Meier B. Jenzerwurz und Chäslichrut. Pflanzliche Hausmittel für Rinder, Schafe, Ziegen, Schweine und Pferde. 1st ed. Bern: Haupt; 2013.

46. Fintelmann V, Weiss RF. Lehrbuch der Phytotherapie. 10th ed. Stuttgart: Hippokrates Verlag; 2002.

47. Mayer M, Vogl CR, Amorena M, Hamburger M, Walkenhorst M. Treatment of Organic Livestock with Medicinal Plants: A Systematic Review of European Ethnoveterinary Research. Forschende Komplementarmedizin 2014;21(6): 375-86.

48. Franz C, Bauer R, Carle R, Tedesco D, Tubaro A, Zitterl-Eglseer K. Assesment of plants/herbs, plant/herb extracts and their naturally or synthetically produced components as "additives" for use in animal production. CFT/ EFSA/FEEDAP/2005/01 2005.

49. PubMed.gov [https://www.ncbi.nlm.nih.gov/pubmed] access date 201502-16 until 2015-02-19

50. Web of science TM [http://apps.webofknowledge.com] 2015-02-16 until 2015-02-19

51. Thomson Reuters TM: EndNote X7.

52. Burt SA, Reinders RD. Antibacterial activity of selected plant essential oils against Escherichia coli 0157: H7. Lett Appl Microbiol. 2003;36(3):162-7.

53. Fleer $\mathrm{H}$, Verspohl EJ. Antispasmodic activity of an extract from Plantago lanceolata L. and some isolated compounds. Phytomedicine. 2007;14(6):409-15.

54. WHO Collaborating Centre for Drug Statistics Methodology. Guidelines for ATCvet classification 2014. Oslo: 2013.
55. ESCOP. ESCOP Monographs. 2nd ed. Exeter, Stuttgart, New York: European Scientific Cooperative on Phytotherapy and Georg Thieme Verlag; 2003.

56. Biertuempfel A, Vetter A, Lutz J. Possibilities of influencing yield and quality of essential oils by choice of varieties and cultivation measures. Zeitschrift Fur Arznei- \& Gewürzplanzen. 2007;12(1):45-50.

57. Toselli F, Matthias A, Gillam EM. Echinacea metabolism and drug interactions: the case for standardization of a complementary medicine. Life Sci. 2009;85(3-4):97-106.

58. Tamta H, Pugh ND, Balachandran P, Moraes R, Sumiyanto J, Pasco DS. Variability in in vitro macrophage activation by commercially diverse bulk echinacea plant material is predominantly due to bacterial lipoproteins and lipopolysaccharides. J Agric Food Chem. 2008;56(22):10552-6.

59. European Pharmacopoe 8.0 [http://online6.edqm.eu/ep807/]

60. Ayrle H, Schmid K, Disler M, Bischoff T, Stucki K, Zbinden M, Vogl CR, Hamburger M, Walkenhorst M. Plant species reported from Swiss farmers to treat bovine respiratory disease. In: 63rd International Congress and Annual Meeting of the Society for Medicinal Plant and Natural Product Research (GA) August 23 - 27 , 2015, vol. 81. Budapest: Planta Medica; 2015.

61. Olson EJ, Epperson WB, Zeman DH, Fayer R, Hildreth MB. Effects of an allicin-based product on cryptosporidiosis in neonatal calves. J Am Vet Med Assoc. 1998;212(7):987-90.

62. Ghosh S, Mehla RK, Sirohi SK, Roy B. The effect of dietary garlic supplementation on body weight gain, feed intake, feed conversion efficiency, faecal score, faecal coliform count and feeding cost in crossbred dairy calves. Tropl Anim Health Prod. 2010;42(5):961-8.

63. Ghosh S, Mehla RK, Sirohi SK, Tomar SK. Performance of crossbred calves with dietary supplementation of garlic extract. J Anim Physiol Anim Nutr. 2011;95(4):449-55.

64. Dudek K, Sliwa E, Tatara MR. Changes in blood leukocyte pattern in piglets from sows treated with garlic preparations. Bull Vet Inst Pulawy. 2006;50(2):263-7.

65. Yan L, Kim IH. Effects of dietary supplementation of fermented garlic powder on growth performance, apparent total tract digestibility, blood characteristics and faecal microbial concentration in weanling pigs. J Anim Physiol Anim Nutr. 2013;97(3):457-64

66. Hanieh H, Narabara K, Piao M, Gerile C, Abe A, Kondo Y. Modulatory effects of two levels of dietary Alliums on immune response and certain immunological variables, following immunization, in White Leghorn chickens. Anim Sci J. 2010; 81(6):673-80.

67. Truchlinski J, Krauze M, Cendrowska-Pinkosz M, Modzelewska-Banachiewicz B. Influence of garlic, synthetic 1,2,4-triasole derivative and herbal preparation Echinovit $C$ on selected indices of turkey-hens non-specific immunity. Pol J Vet Sci. 2006:9(1):51-5.

68. Ushimaru PI, Barbosa LN, Fernandes AA, Di Stasi LC, Fernandes Jr A. In vitro antibacterial activity of medicinal plant extracts against Escherichia coli strains from human clinical specimens and interactions with antimicrobial drugs. Nat Prod Res. 2012;26(16):1553-7.

69. Palaksha MN, Ahmed M, Das S. Antibacterial activity of garlic extract on streptomycin-resistant Staphylococcus aureus and Escherichia coli solely and in synergism with streptomycin. J Nat Sci Biol Med. 2010;1(1):12-5.

70. Meriga B, Mopuri R, Muralikrishna T. Insecticidal, antimicrobial and antioxidant activities of bulb extracts of Allium sativum. Asian Pac J Trop Med. 2012;5(5):391-5.

71. Karuppiah P, Rajaram S. Antibacterial effect of Allium sativum cloves and Zingiber officinale rhizomes against multiple-drug resistant clinical pathogens. Asian Pac J Trop Biomed. 2012;2(8):597-601.

72. Gull I, Saeed M, Shaukat H, Aslam SM, Samra ZQ, Athar AM. Inhibitory effect of Allium sativum and Zingiber officinale extracts on clinically important drug resistant pathogenic bacteria. Ann Clin Microbiol Antimicrob 2012;11:8.

73. Eja ME, Asikong BE, Abriba C, Arikpo GE, Anwan EE, Enyi-Idoh KH. A comparative assessment of the antimicrobial effects of garlic (Allium sativum) and antibiotics on diarrheagenic organisms. Southeast Asian J Trop Med Public Health. 2007;38(2):343-8.

74. Belguith H, Kthiri F, Chati A, Abu Sofah A, Ben Hamida J, Ladoulsi A. Inhibitory effect of aqueous garlic extract (Allium sativum) on some isolated Salmonella serovars. Afr J Microbiol Res. 2010;4(5):328-38.

75. Abubakar E-MM. Efficacy of crude extracts of garlic (Allium sativum Linn.) against nosocomial Escherichia coli, Staphylococcus aureus, Streptococcus pneumoniea and Pseudomonas aeruginosa. Journal of Medicinal Plants Research. 2009;3(4):179-85.

76. Kuo CH, Lee SH, Chen KM, Lii CK, Liu CT. Effect of garlic oil on neutrophil infiltration in the small intestine of endotoxin-injected rats and its association 
with levels of soluble and cellular adhesion molecules. J Agric Food Chem. 2011:59(14):7717-25.

77. Hofbauer R, Frass M, Gmeiner B, Kaye AD, Frost EA. Effects of garlic extract (Allium sativum) on neutrophil migration at the cellular level. Heart disease (Hagerstown, Md). 2001;3(1):14-7.

78. Liu C-T, Su H-M, Lii C-K, Sheen L-Y. Effect of Supplementation with Garlic Oil on Activity of Th1 and Th2 Lymphocytes from Rats. Planta Med. 2009;75(3):205-10.

79. Daneshmandi S, Hajimoradi M, Ahmadabad HN, Hassan ZM, Roudbary M, Ghazanfari T. Effect of $14-\mathrm{kDa}$ and $47-\mathrm{kDa}$ protein molecules of age garlic extract on peritoneal macrophages. Immunopharmacol Immunotoxicol. 2011;33(1):21-7

80. Carter GT, Duong V, Ho S, Ngo KC, Greer CL, Weeks DL. Side effects of commonly prescribed analgesic medications. Phys Med Rehabil Clin N Am. 2014;25(2):457-70.

81. Harifforoosh S, Asghar W, Jamali F. Adverse effects of nonsteroidal antiinflammatory drugs: an update of gastrointestinal, cardiovascular and renal complications. J Pharm Pharm Sci. 2013;16(5):821-47.

82. Saller R, Pfister-Hotz G, Iten F, Melzer J, Reichling J. Iberogast (R): A modern phytotherapeutic combined herbal drug for the treatment of functional disorders of the gastrointestinal tract (dyspepsia, irritable bowel syndrome) from phytomedicine to 'evidence based phytotherapy'. A systematic review. Forsch Komplementarmed Klass Naturheilkd. 2002;9:1-20.

83. Alqasoumi S, Khan TH, Al-Yahya M, Al-Mofleh I, Rafatullah S. Effect of Acute and Chronic Treatment of Common Spices in Swiss Albino Mice: A Safety Assessment Study. Int J Pharmacol. 2012;8(2):80-90.

84. Ungemach FR. Anhang 1, Umrechnung von Humandosierungen für Tiere. In: Löscher W, Ungemach FR, Kroker R, editors. Grundlagen der Pharmakotherapie bei Haus- und Nutztieren. 2nd ed. Berlin und Hamburg: Paul Parey; 1994. p. 400-1.

85. Micklefield GH, Greving I, May B. Effects of peppermint oil and caraway oil on gastroduodenal motility. Phytotherapy research : PTR. 2000;14(1): 20-3.

86. Asao T, Kuwano H, Ide M, Hirayama I, Nakamura Jl, Fujita Kl, Horiuti R. Spasmolytic effect of peppermint oil in barium during double-contrast barium enema compared with Buscopan. Clin Radiol. 2003;58(4):301-5.

87. Imagawa A, Hata H, Nakatsu M, Yoshida Y, Takeuchi K, Inokuchi T, Imada T, Kohno Y, Takahara M, Matsumoto K, et al. Peppermint oil solution is useful as an antispasmodic drug for esophagogastroduodenoscopy, especially for elderly patients. Dig Dis Sci. 2012;57(9):2379-84.

88. Amato A, Liotta R, Mule F. Effects of menthol on circular smooth muscle of human colon: analysis of the mechanism of action. Eur J Pharmacol. 2014;740:295-301.

89. de Sousa AA, Soares PM, de Almeida AN, Maia AR, de Souza EP, Assreuy AM. Antispasmodic effect of Mentha piperita essential oil on tracheal smooth muscle of rats. J Ethnopharmacol. 2010;130(2):433-6.

90. McKay DL, Blumberg JB. A review of the bioactivity and potential health benefits of peppermint tea (Mentha piperita L.). Phytotherapy research : PTR. 2006;20(8):619-33.

91. Barnes J, Anderson LA, Gibbons S, Phillipson JD. Echinacea species (Echinacea angustifolia (DC.) Hell., Echinacea pallida (Nutt.) Nutt., Echinacea purpurea (L.) Moench): a review of their chemistry, pharmacology and clinical properties. J Pharm Pharmacol. 2005;57(8):929-54.

92. Bauer R. New knowledge regarding the effect and effectiveness of Echinacea purpurea extracts. Wien Med Wochenschr. 2002;152(15-16):407-11.

93. Maass N, Bauer J, Paulicks BR, Bohmer BM, Roth-Maier DA. Efficiency of Echinacea purpurea on performance and immune status in pigs. J Anim Physiol Anim Nutr. 2005;89(7-8):244-52.

94. Jawad M, Schoop R, Suter A, Klein P, Eccles R. Safety and Efficacy Profile of Echinacea purpurea to Prevent Common Cold Episodes: A Randomized, Double-Blind, Placebo-Controlled Trial. Evid Based Complement Altern Med: eCAM. 2012;2012:841315

95. Goel V, Lovlin R, Barton R, Lyon MR, Bauer R, Lee TD, Basu TK. Efficacy of a standardized echinacea preparation (Echinilin) for the treatment of the common cold: a randomized, double-blind, placebo-controlled trial. J Clin Pharm Ther. 2004;29(1):75-83.

96. Hermann JR, Honeyman MS, Zimmerman JJ, Thacker BJ, Holden PJ, Chang CC. Effect of dietary Echinacea purpurea on viremia and performance in porcine reproductive and respiratory syndrome virus-infected nursery pigs. J Anim Sci. 2003;81(9):2139-44.

97. Modaresi M. Effect of Echinacea purpura Hydro Alcoholic Extract on the Blood Parameters in Mice. Asian J Chem. 2013;25(3):1373-5.
98. O'Neill W, McKee S, Clarke AF. Immunological and haematinic consequences of feeding a standardised Echinacea (Echinacea angustifolia) extract to healthy horses. Equine Vet J. 2002;34(3):222-7.

99. Groom SN, Johns T, Oldfield PR. The potency of immunomodulatory herbs may be primarily dependent upon macrophage activation. J Med Food. 2007;10(1):73-9.

100. Stevenson LM, Matthias A, Banbury L, Penman KG, Bone KM, Leach DL, Lehmann RP. Modulation of macrophage immune responses by Echinacea. Molecules (Basel, Switzerland). 2005;10(10):1279-85.

101. Wagner H, Jurcic K. Immunological studies of Revitonil, a phytopharmaceutical containing Echinacea purpurea and Glycyrrhiza glabra root extract. Phytomedicine : international journal of phytotherapy and phytopharmacology. 2002;9(5):390-7.

102. Cech NB, Tutor K, Doty BA, Spelman K, Sasagawa M, Raner GM, Wenner CA. Liver enzyme-mediated oxidation of Echinacea purpurea alkylamides: production of novel metabolites and changes in immunomodulatory activity. Planta Med. 2006;72(15):1372-7.

103. Vimalanathan S, Arnason JT, Hudson JB. Anti-inflammatory activities of Echinacea extracts do not correlate with traditional marker components. Pharm Biol. 2009;47(5):430-5.

104. Sharma M, Anderson SA, Schoop R, Hudson JB. Induction of multiple proinflammatory cytokines by respiratory viruses and reversal by standardized Echinacea, a potent antiviral herbal extract. Antiviral Res. 2009:83(2):165-70.

105. Todd DA, Gulledge TV, Britton ER, Oberhofer M, Leyte-Lugo M, Moody AN, Shymanovich T, Grubbs LF, Juzumaite M, Graf TN, et al. Ethanolic Echinacea purpurea Extracts Contain a Mixture of Cytokine-Suppressive and CytokineInducing Compounds, Including Some That Originate from Endophytic Bacteria. PLoS One. 2015;10(5):e0124276.

106. ESCOP. ESCOP Monographs, Supplement 2009. 2nd ed. Exeter, Stuttgart, New York: European Scientific Cooperative on Phytotherapy and Georg Thieme Verlag; 2009.

107. Parnham MJ. Benefit-risk assessment of the squeezed sap of the purple coneflower (Echinacea purpurea) for long-term oral immunostimulation. Phytomedicine. 1996:3(1):95-102.

108. Gruenwald J, Graubaum HJ, Busch R. Efficacy and tolerability of a fixed combination of thyme and primrose root in patients with acute bronchitis. A double-blind, randomized, placebo-controlled clinical trial. Arzneimittelforschung. 2005;55(11):669-76.

109. Kemmerich B, Eberhardt R, Stammer H. Efficacy and tolerability of a fluid extract combination of thyme herb and ivy leaves and matched placebo in adults suffering from acute bronchitis with productive cough - A prospective, double-blind, placebo-controlled clinical trial. Arzneimittel-Forschung-Drug Research. 2006:56(9):652-60.

110. Kemmerich B. Evaluation of efficacy and tolerability of a fixed combination of dry extracts of thyme herb and primrose root in adults suffering from acute bronchitis with productive cough. A prospective, double-blind, placebo-controlled multicentre clinical trial. Arzneimittelforschung. 2007;57(9):607-15.

111. Schmidt E, Wanner J, Hoeferl M, Jirovetz L, Buchbauer G, Gochev V, Girova T, Stoyanova A, Geissler M. Chemical Composition, Olfactory Analysis and Antibacterial Activity of Thymus vulgaris Chemotypes Geraniol, 4-Thujanol/ Terpinen-4-ol, Thymol and Linalool Cultivated in Southern France. Nat Prod Commun. 2012;7(8):1095-8.

112. Wienkotter N, Kinzinger U, Schierstedt D, Begrow F, Verspohl EJ. Pharmacological effects of a thyme extract (Thymus vulgaris L.) on beta(2)-receptors and mucociliary clearance. Naunyn-Schmiedebergs Archives of Pharmacology. 2006:372:92.

113. Begrow F, Engelbertz J, Felstel B, Lehnfeld R, Bauer K, Verspohl EJ. Impact of Thymol in Thyme Extracts on Their Antispasmodic Action and Ciliary Clearance. Planta Med. 2010;76(4):311-8.

114. Boskabady MH, Aslani MR, Kiani S. Relaxant effect of Thymus vulgaris on guinea-pig tracheal chains and its possible mechanism(s). Phytother Res. 2006;20(1):28-33.

115. Keyhanmanesh R, Boskabady MH. Relaxant effects of different fractions from Tymus vulgaris on guinea-pig tracheal chains. Biol Res. 2012;45(1):67-73.

116. Engelbertz J, Lechtenberg M, Studt L, Hensel A, Verspohl EJ. Bioassay-guided fractionation of a thymol-deprived hydrophilic thyme extract and its antispasmodic effect. J Ethnopharmacol. 2012;141(3):848-53.

117. Vigo E, Cepeda A, Gualillo O, Perez-Fernandez R. In-vitro anti-inflammatory effect of Eucalyptus globulus and Thymus vulgaris: nitric oxide inhibition in J774A.1 murine macrophages. J Pharm Pharmacol. 2004;56(2):257-63. 
118. Stojkovic D, Glamoclija J, Ciric A, Nikolic M, Ristic M, Siljegovic J, Sokovic M. Investigation on antibacterial synergism of Origanum vulgare and Thymzs vulgaris essential oils. Archives of Biological Sciences. 2013;65(2):639-43.

119. Sienkiewicz M, Lysakowska M, Denys P, Kowalczyk E. The Antimicrobial Activity of Thyme Essential Oil Against Multidrug Resistant Clinical Bacterial Strains. Microb Drug Resist. 2012;18(2):137-48.

120. Santurio DF, Kunz de Jesus FP, Zanette RA, Schlemmer KB, Fraton A, Martins Fries LL. Antimicrobial Activity of the Essential Oil of Thyme and of Thymol against Escherichia coli Strains. Acta Scientiae Veterinariae 2014;42:1234.

121. Oyewole OL, Owoseni AA, Faboro EO. Studies on medicinal and toxicological properties of Cajanus cajan, Ricinus communis and Thymus vulgaris leaf extracts. Journal of Medicinal Plants Research. 2010;4(19):2004-8.

122. Buechi S, Vogelin R, von Eiff MM, Ramos M, Melzer J. Open trial to assess aspects of safety and efficacy of a combined herbal cough syrup with ivy and thyme. Forschende Komplementarmedizin und klassische Naturheilkunde $=$ Research in complementary and natural classical medicine. 2005;12(6):328-32.

123. Hiller K, Melzig MF. Lexikon der Arzneipflanzen und Drogen. 2nd ed. Heidelberg: Spektrum akademischer Verlag; 2010.

124. Bruins MJ, Vente-Spreeuwenberg MA, Smits CH, Frenken LG. Black tea reduces diarrhoea prevalence but decreases growth performance in enterotoxigenic Escherichia coli-infected post-weaning piglets. J Anim Physiol Anim Nutr. 2011;95(3):388-98.

125. Zanchi R, Canzi E, Molteni L, Scozzoli M. Effect of Camellia sinensis L. whole plant extract on piglet intestinal ecosystem. Ann Microbiol. 2008;58(1):147-52.

126. Smee DF, Hurst BL, Wong MH. Effects of TheraMax on influenza virus infections in cell culture and in mice. Antivir Chem Chemother. 2011;21(6):231-7.

127. Lee HJ, Lee YN, Youn HN, Lee DH, Kwak JH, Seong BL, Lee JB, Park SY, Choi IS, Song CS. Anti-influenza virus activity of green tea by-products in vitro and efficacy against influenza virus infection in chickens. Poult Sci. 2012;91(1):66-73.

128. Yanagimoto K, Ochi H, Lee KG, Shibamoto T. Antioxidative activities of volatile extracts from green tea, oolong tea, and black tea. J Agric Food Chem. 2003;51(25):7396-401

129. Sawai Y, Moon JH, Sakata K, Watanabe N. Effects of structure on radicalscavenging abilities and antioxidative activities of tea polyphenols: NMR analytical approach using 1,1-diphenyl-2-picrylhydrazyl radicals. J Agric Food Chem. 2005;53(9):3598-604.

130. Ling JX, Wei F, Li N, Li JL, Chen L, Liu YY, Luo F, Xiong HR, Hou W, Yang $\mathrm{ZQ}$. Amelioration of influenza virus-induced reactive oxygen species formation by epigallocatechin gallate derived from green tea. Acta Pharmacol Sin. 2012;33(12):1533-41.

131. Chen BT, Li WX, He RR, Li YF, Tsoi B, Zhai YJ, Kurihara H. Anti-inflammatory effects of a polyphenols-rich extract from tea (Camellia sinensis) flowers in acute and chronic mice models. Oxid Med Cell Longev. 2012;2012:537923.

132. Chattopadhyay P, Besra SE, Gomes A, Das M, Sur P, Mitra S, Vedasiromoni JR. Anti-inflammatory activity of tea (Camellia sinensis) root extract. Life Sci. 2004;74(15):1839-49.

133. Monobe M, Ema K, Kato F, Maeda-Yamamoto M. Immunostimulating activity of a crude polysaccharide derived from green tea (Camellia sinensis) extract. J Agric Food Chem. 2008;56(4):1423-7.

134. Matsumoto K, Yamada H, Takuma N, Niino H, Sagesaka YM. Effects of green tea catechins and theanine on preventing influenza infection among healthcare workers: a randomized controlled trial. BMC Complement Altern Med. 2011;11:15.

135. Hsu Y-W, Tsai C-F, Chen W-K, Huang C-F, Yen C-C. A subacute toxicity evaluation of green tea (Camellia sinensis) extract in mice. Food Chem Toxicol. 2011:49(10):2624-30.

136. Sarma DN, Barrett ML, Chavez ML, Gardiner P, Ko R, Mahady GB, Marles RJ, Pellicore LS, Giancaspro Gl, Dog TL. Safety of green tea extracts - A systematic review by the US Pharmacopeia. Drug Saf. 2008;31(6):469-84.

137. Chan PC, Ramot Y, Malarkey DE, Blackshear P, Kissling GE, Travlos G, Nyska A. Fourteen-Week Toxicity Study of Green Tea Extract in Rats and Mice. Toxicol Pathol. 2010;38(7):1070-84.

138. Borsuk OS, Masnaya NV, Sherstoboev EY, Isaykina NV, Kalinkina Gl, Reihart DV. Effects of drugs of plant origin on the development of the immune response. Bull Exp Biol Med. 2011;151(2):194-6.

139. Saha S, Nosal'ova G, Ghosh D, Fleskova D, Capek P, Ray B. Structural features and in vivo antitussive activity of the water extracted polymer from Glycyrrhiza glabra. Int J Biol Macromol. 2011;48(4):634-8.

140. Liu B, Yang J, Wen Q, Li Y. Isoliquiritigenin, a flavonoid from licorice, relaxes guinea-pig tracheal smooth muscle in vitro and in vivo: Role of cGMP/PKG pathway. Eur J Pharmacol. 2008;587(1-3):257-66.
141. Chen G, Zhu L, Liu Y, Zhou Q, Chen H, Yang J. Isoliquiritigenin, a Flavonoid from Licorice, plays a Dual Role in regulating Gastrointestinal Motility in vitro and in vivo. Phytother Res. 2009;23(4):498-506.

142. Kim HK, Park Y, Kim HN, Choi BH, Jeong HG, Lee DG, Hahm KS. Antimicrobial mechanism of beta-glycyrrhetinic acid isolated from licorice, Glycyrrhiza glabra. Biotechnol Lett. 2002;24(22):1899-902.

143. Irani M, Sarmadi M, Bernard F, Ebrahimi Pour GH, Shaker Bazarnov H. Leaves Antimicrobial Activity of Glycyrrhiza glabra L. Iranian journal of pharmaceutical research : IJPR. 2010;9(4):425-8.

144. Laconi S, Madeddu MA, Pompei R. Autophagy Activation and Antiviral Activity by a Licorice Triterpene. Phytother Res. 2014;28(12):1890-2.

145. Knipping K, Garssen J, van't Land B. An evaluation of the inhibitory effects against rotavirus infection of edible plant extracts. Virol J 2012;9:137.

146. Isbrucker RA, Burdock GA. Risk and safety assessment on the consumption of Licorice root (Glycyrrhiza sp.), its extract and powder as a food ingredient, with emphasis on the pharmacology and toxicology of glycyrrhizin. Regulatory toxicology and pharmacology : RTP. 2006;46(3):167-92.

147. Candan F, Unlu M, Tepe B, Daferera D, Polissiou M, Sokmen A, Akpulat HA. Antioxidant and antimicrobial activity of the essential oil and methanol extracts of Achillea millefolium subsp. millefolium Afan. (Asteraceae). J Ethnopharmacol. 2003;87(2-3):215-20.

148. Tajik H, Jalali FSS, Sobhani A, Shahbazi Y, Zadeh MS. In vitro Assessment of Antimicrobial Efficacy of Alcoholic Extract of Achillea Millefolium in Comparison with Penicillin Derivatives. J Anim Vet Adv. 2008;7(4):508-11.

149. Babaei M, Abarghoei ME, Akhavan MM, Ansari R, Vafaei AA, Taherian AA, Mousavi S, Toussy J. Antimotility effect of hydroalcoholic extract of yarrow (Achillea millefolium) on the guinea-pig ileum. Pakistan journal of biological sciences: PJBS. 2007;10(20):3673-7.

150. Lemmens-Gruber R, Marchart E, Rawnduzi P, Engel N, Benedek B, Kopp B. Investigation of the spasmolytic activity of the flavonoid fraction of Achillea millefolium s.I. on isolated guinea-pig ilea. Arzneimittelforschung. 2006;56(8):582-8.

151. Moradi MT, Rafieian-Koupaei M, Imani-Rastabi R, Nasiri J, Shahrani M, Rabiei Z, Alibabaei Z. Antispasmodic effects of yarrow (Achillea millefolium L.) extract in the isolated ileum of rat. African journal of traditional, complementary, and alternative medicines: AJTCAM/African Networks on Ethnomedicines. 2013;10(6):499-503.

152. Yaeesh S, Jamal Q, Khan AU, Gilani AH. Studies on hepatoprotective, antispasmodic and calcium antagonist activities of the aqueous-methanol extract of Achillea millefolium. Phytotherapy research : PTR. 2006;20(7):546-51.

153. Cross DE, McDevitt RM, Hillman K, Acamovic T. The effect of herbs and their associated essential oils on performance, dietary digestibility and gut microflora in chickens from 7 to 28 days of age. Br Poultry Sci. 2007; 48(4):496-506.

154. Borrelli F, Romano B, Fasolino I, Tagliatatela-Scafati O, Aprea G, Capasso R, Capasso F, Bottazzi EC, Izzo AA. Prokinetic effect of a standardized yarrow (Achillea millefolium) extract and its constituent choline: studies in the mouse and human stomach. Neurogastroenterol Motil. 2012;24(2):16471,e90.

155. Al-Mariri A, Safi M. In Vitro Antibacterial Activity of Several Plant Extracts and Oils against Some Gram-Negative Bacteria. Iranian journal of medical sciences. 2014;39(1):36-43.

156. Casella S, Leonardi M, Melai B, Fratini F, Pistelli L. The Role of Diallyl Sulfides and Dipropyl Sulfides in the In Vitro Antimicrobial Activity of the Essential Oil of Garlic, Allium sativum L., and Leek, Allium porrum L. Phytother Res. 2013;27(3):380-3.

157. Gomaa NF, Hashish MH. The inhibitory effect of garlic (Allium sativum) on growth of some microorganisms. J Egypt Public Health Assoc. 2003; 78(5-6):361-72

158. Harris JC, Plummer S, Turner MP, Lloyd D. The microaerophilic flagellate Giardia intestinalis: Allium sativum (garlic) is an effective antigiardial. Microbiology-Uk. 2000;146:3119-27.

159. Kuda T, Iwai A, Yano T. Effect of red pepper Capsicum annuum var. conoides and garlic Allium sativum on plasma lipid levels and cecal microflora in mice fed beef tallow. Food Chem Toxicol. 2004;42(10):1695-700.

160. Sreter T, Szell Z, Varga I. Attempted chemoprophylaxis of cryptosporidiosis in chickens, using diclazuril, toltrazuril, or garlic extract. J Parasitol. 1999; 85(5):989-91.

161. Horie T, Matsumoto H, Kasagi M, Sugiyama A, Kikuchi M, Karasawa C, Awazu S, Itakura Y, Fuwa T. Protective effect of aged garlic extract on the small 
intestinal damage of rats induced by methotrexate administration. Planta Med. 1999;65(6):545-8.

162. Tatara MR, Sliwa E, Dudek K, Kowalik S, Gawron A, Piersiak T, Dobrowolski P, Studzinski T. Effect of aged garlic extract and allicin administration to sows during pregnancy and lactation on body weight gain and gastrointestinal tract development of piglets: Morphological properties of the small intestine. Part II. Bull Vet Inst Pulawy. 2005;49(4):455-64.

163. Valiei M, Shafaghat A, Salimi F. Chemical composition and antimicrobial activity of the flower and root hexane extracts of Althaea officinalis in Northwest Iran. Journal of Medicinal Plants Research. 2011;5(32):6972-6.

164. Watt K, Christofi N, Young R. The detection of antibacterial actions of whole herb tinctures using luminescent Escherichia coli. Phytotherapy research: PTR. 2007;21(12):1193-9.

165. Bandyopadhyay D, Chatterjee TK, Dasgupta A, Lourduraja J, Dastidar SG. In vitro and in vivo antimicrobial action of tea: The commonest beverage of Asia. Biol Pharm Bull. 2005;28(11):2125-7.

166. Ciraj AM, Sulaim J, Mamatha B, Gopalkrishna BK, Shivananda PG. Antibacterial activity of black tea (Camelia sinensis) extract against Salmonella serotypes causing enteric fever. Indian J Med Sci. 2001;55(7): 376-81.

167. Mukherjee D, Bhattacharjee PG, Samanta S. Comparative Profile of the Antimicrobial Activities of Assam, Dooars and Darjeeling Tea Leaves (Camellia sinensis L). Journal of Pure and Applied Microbiology. 2012;6(4):2011-5.

168. Neyestani TR, Khalaji N, Gharavi A. Selective microbiologic effects of tea extract on certain antibiotics against Escherichia coli in vitro. Journal of alternative and complementary medicine (New York, NY). 2007;13(10):1119-24.

169. Reygaert W, Jusufi I. Green tea as an effective antimicrobial for urinary tract infections caused by Escherichia coli. Front Microbiol 2013;4:62.

170. Tiwari RP, Bharti SK, Kaur HD, Dikshit RP, Hoondal GS. Synergistic antimicrobial activity of tea \& antibiotics. Indian J Med Res. 2005;122(1):80-4.

171. Lee J-H, Shim JS, Chung M-S, Lim S-T, Kim KH. In Vitro Anti-Adhesive Activity of Green Tea Extract against Pathogen Adhesion. Phytother Res. 2009;23(4):460-6.

172. Chaudhuri L, Basu S, Seth P, Chaudhuri T, Besra SE, Vedasiromoni JR, Ganguly DK. Prokinetic effect of black tea on gastrointestinal motility. Life Sci. 2000;66(9):847-54.

173. Ratnasooriya WD, Fernando TSP. Antidiarrhoeal activity of Sri Lankan Dust grade Black Tea (Camellia sinensis L.) in mice. Pharmacogn Mag. 2009;5(18): $115-21$.

174. Hawrelak JA, Cattley T, Myers SP. Essential Oils in the Treatment of Intestinal Dysbiosis: A Preliminary in vitro Study. Altern Med Rev. 2009;14(4):380-4.

175. Kacaniova M, Vukovic N, Horska E, Salamon I, Bobkova A, Heba L, Fiskelova M, Vatlak A, Petrova J, Bobko M. Antibacterial activity against Clostridium genus and antiradical activity of the essential oils from different origin J Environ Sci Health B. 2014;49(7):505-12.

176. Mohsenzadeh M. Evaluation of antibacterial activity of selected Iranian essential oils against Staphylococcus aureus and Escherichia coli in nutrient broth medium. Pakistan journal of biological sciences: PJBS. 2007;10(20):3693-7.

177. Al-Essa MK, Shafagoj YA, Mohammed FI, Afifi FU. Relaxant effect of ethano extract of Carum carvi on dispersed intestinal smooth muscle cells of the guinea pig. Pharm Biol. 2010;48(1):76-80.

178. Keshavarz A, Minaiyan M, Ghannadi A, Mahzouni P. Effects of Carum carvi L. (Caraway) extract and essential oil on TNBS-induced colitis in rats. Research in pharmaceutical sciences. 2013;8(1):1-8.

179. Hill LL, Foote JC, Erickson BD, Cerniglia CE, Denny GS. Echinacea purpurea supplementation stimulates select groups of human gastrointestinal tract microbiota. J Clin Pharm Ther. 2006;31 (6):599-604.

180. Al Akeel R, Al-Sheikh Y, Mateen A, Syed R, Janardhan K, Gupta VC. Evaluation of antibacterial activity of crude protein extracts from seeds of six different medical plants against standard bacterial strains. Saudi journal of biological sciences. 2014;21 (2):147-51.

181. Aprotosoaie AC, Hancianu M, Poiata A, Tuchilus C, Spac A, Cioana O, Gille E, Stanescu U. In vitro antimicrobial activity and chemical composition of the essential oil of Foeniculum vulgare Mill. Rev Med Chir Soc Med Nat lasi. 2008;112(3):832-6.

182. Bisht DS, Menon KRK, Singhal MK. Comparative Antimicrobial Activity of Essential oils of Cuminum cyminum L. and Foeniculum vulgare Mill. seeds against Salmonella typhimurium and Escherichia coli. Journal of Essential Oil Bearing Plants. 2014;17(4):617-22.
183. Gulfraz M, Mehmood S, Minhas N, Jabeen N, Kausar R, Jabeen K, Arshad G. Composition and antimicrobial properties of essential oil of Foeniculum vulgare. Afr J Biotechnol. 2008;7(24):4364-8.

184. Damyanova S, Stoyanova A. Antimicrobial activity of aromatic products. 14 extracts from fruits of sweet fennel (Foeniculum vulgare Mill. var. dulce Mill.) and coriander (Coriandrum salivum L.). Journal of Essential Oil Bearing Plants. 2007;10(5):440-5.

185. Bulut C, Altiok E, Bayraktar O, Ulku S. Antioxidative and Antimicrobial Screening of 19 Commercial Essential Oils in Turkey. In: Edited by Turgut K, Onus AN, Mathe A. I International Medicinal and Aromatic Plants Conference on Culinary Herbs. Volume 826, edn., 2009. 111-116.

186. Costa Brandelli CL, Giordani RB, Attilio De Carli G, Tasca T. Indigenous traditional medicine: in vitro anti-giardial activity of plants used in the treatment of diarrhea. Parasitol Res. 2009;104(6):1345-9.

187. Lee JH, Lee DU, Kim YS, Kim HP. 5-Lipoxygenase Inhibition of the Fructus of Foeniculum vulgare and Its Constituents. Biomol Ther. 2012;20(1):113-7.

188. Alexandrovich I, Rakovitskaya O, Kolmo E, Sidorova T, Shushunov S. The effect of fennel (Foeniculum vulgare) seed oil emulsion in infantile colic: A randomized, placebo-controlled study. Altern Ther Health Med. 2003;9(4):58-61.

189. Capasso R, Savino F, Capasso F. Effects of the herbal formulation ColiMil (R) on upper gastrointestinal transit in mice in vivo. Phytother Res. 2007;21(10):999-1001.

190. Gupta VK, Fatima A, Faridi U, Negi AS, Shanker K, Kumar JK, Rahuja N, Luqman S, Sisodia BS, Saikia D, et al. Antimicrobial potential of Glycyrrhiza glabra roots. J Ethnopharmacol. 2008;1 16(2):377-80.

191. Tasdelen Fisgin N, Tanriverdi Cayci Y, Coban AY, Ozatli D, Tanyel E, Durupinar B, Tulek N. Antimicrobial activity of plant extract Ankaferd Blood Stopper. Fitoterapia. 2009;80(1):48-50.

192. Walter C, Shinwari ZK, Afzal I, Malik RN. Antibacterial activity in herbal products used in Pakistan. Pak J Bot. 2011:43:155-62.

193. Shinwari ZK, Khan I, Naz S, Hussain A. Assessment of antibacterial activity of three plants used in Pakistan to cure respiratory diseases. Afr J Biotechnol. 2009;8(24):7082-6.

194. Heinle H, Hagelauer D, Pascht U, Kelber O, Weiser D. Intestinal spasmolytic effects of STW 5 (Iberogast (R)) and its components. Phytomedicine: international journal of phytotherapy and phytopharmacology. 2006;13:75-9.

195. Chandrasekaran CV, Deepak HB, Thiyagarajan P, Kathiresan S, Sangli GK, Deepak M, Agarwal A. Dual inhibitory effect of Glycyrrhiza glabra (GutGard (TM)) on COX and LOX products. Phytomedicine : international journal of phytotherapy and phytopharmacology. 2011;18(4):278-84.

196. Puram S, Suh HC, Kim SU, Bethapudi B, Joseph JA, Agarwal A, Kudiganti V. Effect of GutGard in the Management of Helicobacter pylori: A Randomized Double Blind Placebo Controlled Study. Evid Based Complement Altern Med 2013.

197. Sancar M, Hantash T, Okuyan B, Apikoglu-Rabus S, Cirakli Z, Gulluoglu MG, Izzettin FV. Comparative effectiveness of Glycyrrhiza glabra vs. omeprazole and misoprostol for the treatment of aspirin-induced gastric ulcers. Afr J Pharm Pharmacol. 2009;3(12):615-20.

198. Srinivasan D, Ramaswamy S, Sengottuvelu S. Prokinetic Effect of Polyherbal Formulation on Gastrointestinal Tract. Pharmacogn Mag. 2009:5(17):37-42.

199. Palla AH, Khan NA, Bashir S, Ur-Rehman N, Iqbal J, Gilani AH. Pharmacological basis for the medicinal use of Linum usitatissimum (Flaxseed) in infectious and non-infectious diarrhea. J Ethnopharmacol. 2015;160:61-8.

200. Strzalkowski AK, Godlewski MM, Hallay N, Kulasek G, Gajewski Z, Zabielski R. The effect of supplementing sow with bioactive substances on neonatal small intestinal epithelium. Journal of physiology and pharmacology : an official journal of the Polish Physiological Society 2007;58 Suppl 3:115-22.

201. Holman DB, Baurhoo B, Chenier MR. Temporal analysis of the effect of extruded flaxseed on the swine gut microbiota. Can J Microbiol. 2014; 60(10):649-59.

202. Abdoul-Latif FM, Mohamed N, Edou P, Ali AA, Djama SO, Obame L-C, Bassole IHN, Dicko MH. Antimicrobial and antioxidant activities of essential oil and methanol extract of Matricaria chamomilla L. from Djibouti. Journal of Medicinal Plants Research. 2011;5(9):1512-7.

203. Munir N, labal AS, Altaf I, Bashir R, Sharif N, Saleem F, Naz S. Evaluation of antioxidant and antimicrobial potential of two endangered plant species atropa belladonna and matricaria chamomilla. African journal of traditional, complementary, and alternative medicines: AJTCAM/African Networks on Ethnomedicines. 2014;11(5):111-7. 
204. Silva NC, Barbosa L, Seito LN, Fernandes Jr A. Antimicrobial activity and phytochemical analysis of crude extracts and essential oils from medicinal plants. Nat Prod Res. 2012;26(16):1510-4.

205. Ammon HP, Kelber O, Okpanyi SN. Spasmolytic and tonic effect of Iberogast (STW 5) in intestinal smooth muscle. Phytomedicine : international journal of phytotherapy and phytopharmacology. 2006;13 Suppl 5:67-74.

206. Maschi O, Cero ED, Galli GV, Caruso D, Bosisio E, Dell'Agli M. Inhibition of human CAMP-phosphodiesterase as a mechanism of the spasmolytic effect of Matricaria recutita L. J Agric Food Chem. 2008;56(13):5015-20.

207. Schemann M, Michel K, Zeller F, Hohenester B, Ruehl A. Region-specific effects of STW 5 (Iberogast (R)) and its components in gastric fundus, corpus and antrum. Phytomedicine : international journal of phytotherapy and phytopharmacology. 2006;13:90-9.

208. Storr M, Sibaev A, Weiser D, Kelber O, Schirra J, Goke B, Allescher HD. Herbal extracts modulate the amplitude and frequency of slow waves in circular smooth muscle of mouse small intestine. Digestion. 2004;70(4):257-64.

209. Calzada F, Arista R, Perez H. Effect of plants used in Mexico to treat gastrointestinal disorders on charcoal-gum acacia-induced hyperperistalsis in rats. J Ethnopharmacol. 2010;128(1):49-51.

210. Sebai H, Jabri MA, Souli A, Rtibi K, Selmi S, Tebourbi O, El-Benna J, Sakly M. Antidiarrheal and antioxidant activities of chamomile (Matricaria recutita L.) decoction extract in rats. J Ethnopharmacol. 2014;152(2):327-32.

211. Carvalho JCT, Vignoli W, de Souza GHB, Ujikawa K, Neto JJ: Antimicrobial activity of essential oils from plants used in Brazilian popular medicine. In: Edited by Martino V, Caffini N, Lappa A, Schilcher H, Phillipson JD, Tchernitchin A, Debenedetti S, Acevedo C. Second World Congress on Medicinal and Aromatic Plants for Human Welfare Wocmap-2: Pharmacognosy, Pharmacology, Phytomedicines, Toxicology. 1999. 77-81.

212. Pattnaik S, Subramanyam VR, Rath CC. Effect of essential oils on the viability and morphology of Escherichia coli (SP-11). Microbios. 1995;84(340):195-9.

213. Saeed S, Tariq P. Antibacterial activities of Mentha piperita, Pisum sativum and Momordica charantia. Pak J Bot. 2005;37(4):997-1001.

214. Schelz Z, Molnar J, Hohmann J. Antimicrobial and antiplasmid activities of essential oils. Fitoterapia. 2006;77(4):279-85.

215. Thompson A, Meah D, Ahmed N, Conniff-Jenkins R, Chileshe E, Phillips CO, Claypole TC, Forman DW, Row PE. Comparison of the antibacterial activity of essential oils and extracts of medicinal and culinary herbs to investigate potential new treatments for irritable bowel syndrome. BMC Complement Altern Med. 2013;13:338.

216. Toroglu S. In-vitro antimicrobial activity and synergistic/antagonistic effect of interactions between antibiotics and some spice essential oils. Journal of environmental biology/Academy of Environmental Biology, India. 2011;32(1):23-9.

217. Jirovetz L, Buchbauer G, Bail S, Denkova Z, Slavchev A, Stoyanova A, Schmidt E, Geissler M. Antimicrobial Activities of Essential Oils of Mint and Peppermint as Well as Some of Their Main Compounds. J Essent Oil Res. 2009;21(4):363-6.

218. Jalilzadeh-Amin G, Maham M, Dalir-Naghadeh B, Kheiri F. Effects of Mentha longifolia essential oil on ruminal and abomasal longitudinal smooth muscle in sheep. J Essent Oil Res. 2012;24(1):61-9.

219. Sharifi SD, Khorsandi SH, Khadem AA, Salehi A, Moslehi H. The effect of four medicinal plants on the performance, blood biochemical traits and ileal microflora of broiler chicks. Veterinarski Arhiv. 2013;83(1):69-80.

220. Bruno DG, Massami Kitamura Martins SM, Parazzi LJ, Afonso ER, Del Santo TA, Novita Teixeira SM, Moreno AM, Moretti ASA. Phytogenic feed additives in piglets challenged with Salmonella Typhimurium. Revista Brasileira De Zootecnia-Brazilian Journal of Animal Science. 2013;42(2):137-43.

221. Micklefield G, Jung O, Greving I, May B. Effects of intraduodenal application of peppermint oil (WS(R) 1340) and caraway oil (WS(R) 1520) on gastroduodenal motility in healthy volunteers. Phytotherapy research : PTR. 2003;17(2):135-40.

222. Yamamoto N, Nakai Y, Sasahira N, Hirano K, Tsujino T, Isayama H, Komatsu Y, Tada M, Yoshida H, Kawabe T, et al. Efficacy of peppermint oil as an antispasmodic during endoscopic retrograde cholangiopancreatography. J Gastroenterol Hepatol. 2006;21(9):1394-8.

223. Bezerra Alves JG, Coelho Moraes de Brito RdC, Cavalcanti TS. Effectiveness of Mentha piperita in the Treatment of Infantile Colic: A Crossover Study. Evidence-Based Complementary and Alternative Medicine 2012.

224. Becerril R, Nerin C, Gomez-Lus R. Evaluation of bacterial resistance to essential oils and antibiotics after exposure to oregano and cinnamon essential oils. Foodborne Pathog Dis. 2012;9(8):699-705.
225. da Costa AC, Santos BH C d, Santos Filho L, Lima EO. Antibacterial activity of the essential oil of Origanum vulgare L. (Lamiaceae) against bacterial multiresistant strains isolated from nosocomial patients. Revista Brasileira De Farmacognosia-Brazilian Journal of Pharmacognosy. 2009;19(1B):236-41.

226. Dorman HJ, Deans SG. Antimicrobial agents from plants: antibacterial activity of plant volatile oils. J Appl Microbiol. 2000;88(2):308-16.

227. Fabian D, Sabol M, Domaracka K, Bujnakova D. Essential oils-their antimicrobial activity against Escherichia coli and effect on intestinal cell viability. Toxicology in vitro : an international journal published in association with BIBRA. 2006; 20(8):1435-45.

228. Friedman M, Henika PR, Mandrell RE. Bactericidal activities of plant essential oils and some of their isolated constituents against Campylobacter jejuni, Escherichia coli, Listeria monocytogenes, and Salmonella enterica. J Food Prot. 2002;65(10):1545-60.

229. Hulankova R, Borilova G. In vitro combined effect of oregano essential oil and caprylic acid against Salmonella serovars, Escherichia coli O157:H7, Staphylococcus aureus and Listeria monocytogenes. Acta Vet Brno. 2011; 80(4):343-8.

230. Marino M, Bersani C, Comi G. Impedance measurements to study the antimicrobial activity of essential oils from Lamiaceae and Compositae. Int J Food Microbiol. 2001;67(3):187-95.

231. Mathlouthi N, Bouzaienne T, Oueslati I, Recoquillay F, Hamdi M, Urdaci M, Bergaoui R. Use of rosemary, oregano, and a commercial blend of essential oils in broiler chickens: in vitro antimicrobial activities and effects on growth performance. J Anim Sci. 2012;90(3):813-23.

232. Ouwehand AC, Tiihonen K, Kettunen H, Peuranen S, Schulze H, Rautonen N. In vitro effects of essential oils on potential pathogens and beneficial members of the normal microbiota. Vet Med. 2010;55(2):71-8.

233. Pogany Simonova M, Laukova A, Haviarova M. Pseudomonads from rabbits and their sensitivity to antibiotics and natural antimicrobials. Res Vet Sci. 2010;88(2):203-7.

234. Sarac N, Ugur A. Antimicrobial activities of the essential oils of Origanum onites L., Origanum vulgare L. subspecies hirtum (Link) letswaart, Satureja thymbra L., and Thymus cilicicus Boiss. \& Bal. growing wild in Turkey. J Med Food. 2008;11(3):568-73.

235. Si H, Hu J, Liu Z, Zeng Z-I. Antibacterial effect of oregano essential oil alone and in combination with antibiotics against extended-spectrum betalactamase-producing Escherichia coli. FEMS Immunol Med Microbiol. 2008;53(2):190-4.

236. Sokovic M, Glamoclija J, Marin PD, Brkic D, van Griensven L. Antibacterial effects of the essential oils of commonly consumed medicinal herbs using an in vitro model. Molecules (Basel, Switzerland). 2010;15(11):7532-46.

237. Strompfova $\vee$, Laukova A. Enterococci from piglets-probiotic properties and responsiveness to natural antibacterial substances. Folia Microbiol. 2009; 54(6):538-44.

238. Dahiya P, Purkayastha S. Phytochemical screening and antimicrobial activity of some medicinal plants against multi-drug resistant bacteria from clinical isolates. Indian journal of pharmaceutical sciences. 2012;74(5):443-50.

239. Karakaya S, El SN, Karagozlu N, Sahin S. Antioxidant and Antimicrobial Activities of Essential Oils Obtained from Oregano (Origanum vulgare ssp hirtum) by Using Different Extraction Methods. J Med Food. 2011:14(6):645-52.

240. Bimczok D, Rau H, Sewekow E, Janczyk P, Souffrant WB, Rothkotter HJ. Influence of carvacrol on proliferation and survival of porcine lymphocytes and intestinal epithelial cells in vitro. Toxicology in vitro : an international journal published in association with BIBRA. 2008;22(3):652-8.

241. Manzanilla EG, Perez JF, Martin M, Kamel C, Baucells F, Gasa J. Effect of plant extracts and formic acid on the intestinal equilibrium of early-weaned pigs. J Anim Sci. 2004:82(11):3210-8

242. Batungbacal MR, Hilomen GV, Luis ES, Centeno JR, Carandang NF. Comparative efficacy of oregano (Origanum vulgare) extract and amprolium in the control of coccidiosis and their effect on broiler performance. Philippine Journal of Veterinary Medicine. 2007:44(2):91-9.

243. Giannenas I, Florou-Paneri P, Papazahariadou M, Christaki E, Botsoglou NA Spais AB. Effect of dietary supplementation with oregano essential oil on performance of broilers after experimental infection with Eimeria tenella. Arch Tierernahr. 2003:57(2):99-106.

244. Basmacioglu Malayoglu H, Baysal S, Misirlioglu Z, Polat M, Yilmaz H, Turan N. Effects of oregano essential oil with or without feed enzymes on growth performance, digestive enzyme, nutrient digestibility, lipid metabolism and 
immune response of broilers fed on wheat-soybean meal diets. Br Poultry Sci. 2010;51(1):67-80.

245. Henn JD, Bertol TM, de Moura NF, Coldebella A, de Brum PA R, Casagrande M. Oregano essential oil as food additive for piglets: antimicrobial and antioxidant potential. Revista Brasileira De Zootecnia-Brazilian Journal of Animal Science. 2010:39(8):1761-7.

246. Ariza-Nieto C, Bandrick M, Baidoo SK, Anil L, Molitor TW, Hathaway MR. Effect of dietary supplementation of oregano essential oils to sows on colostrum and milk composition, growth pattern and immune status of suckling pigs. J Anim Sci. 2011;89(4):1079-89.

247. Bukovska A, Cikos S, Juhas S, I'kova G, Rehak P, Koppel J. Effects of a combination of thyme and oregano essential oils on TNBS-induced colitis in mice. Mediators Inflamm. 2007;2007:23296.

248. Bampidis VA, Christodoulou V, Florou-Paneri P, Christaki E. Effect of dried oregano leaves versus neomycin in treating newborn calves with colibacillosis. Journal of Veterinary Medicine Series a-Physiology Pathology Clinical Medicine. 2006:53(3):154-6.

249. Sipponen A, Laitinen K. Antimicrobial properties of natural coniferous rosin in the European Pharmacopoeia challenge test. APMIS : acta pathologica, microbiologica, et immunologica Scandinavica. 2011;119(10):720-4.

250. Al-Bayati FA. Synergistic antibacterial activity between Thymus vulgaris and Pimpinella anisum essential oils and methanol extracts. J Ethnopharmacol. 2008;116(3):403-6.

251. Gradinaru AC, Miron A, Trifan A, Spac A, Brebu M, Aprotosoaie AC. Screening of antibacterial effects of anise essential oil alone and in combination with conventional antibiotics against Streptococcus pneumoniae clinical isolates. Rev Med Chir Soc Med Nat lasi. 2014;118(2):537-43.

252. Abu-Darwish MS, Al-Ramamneh EA, Kyslychenko VS, Karpiuk UV. The antimicrobial activity of essential oils and extracts of some medicinal plants grown in Ash-shoubak region - South of Jordan. Pak J Pharm Sci. 2012;25(1):239-46.

253. Prabuseenivasan S, Jayakumar M, Ignacimuthu S. In vitro antibacterial activity of some plant essential oils. BMC Complement Altern Med. 2006;6:39.

254. Darwish RM, Aburjai TA. Effect of ethnomedicinal plants used in folklore medicine in Jordan as antibiotic resistant inhibitors on Escherichia coli. BMC Complement Altern Med. 2010;10:9.

255. Tirapelli CR, de Andrade CR, Cassano AO, De Souza FA, Ambrosio SR, da Costa FB, de Oliveira AM. Antispasmodic and relaxant effects of the hidroalcoholic extract of Pimpinella anisum (Apiaceae) on rat anococcygeus smooth muscle. J Ethnopharmacol. 2007;110(1):23-9.

256. Ivarsson E, Frankow-Lindberg BE, Andersson HK, Lindberg JE. Growth performance, digestibility and faecal coliform bacteria in weaned piglets fed a cereal-based diet including either chicory (Cichorium intybus $\mathrm{L}$ ) or ribwort (Plantago lanceolata L) forage. Animal : an international journal of animal bioscience. 2011;5(4):558-64.

257. Subbotina MD, Timchenko VN, Vorobyov MM, Konunova YS, Aleksandrovih YS, Shushunov S. Effect of oral administration of tormentil root extract (Potentilla tormentilla) on rotavirus diarrhea in children: a randomized double blind, controlled trial. Pediatr Infect Dis J. 2003;22(8):706-11.

258. Huber R, Ditfurth AV, Amann F, Guethlin C, Rostock M, Trittler R, Kuemmerer K, Merfort I. Tormentil for active ulcerative colitis : An open-label, doseescalating study. J Clin Gastroenterol. 2007:41(9):834-8.

259. Anthony JP, Fyfe L, Stewart D, McDougall GJ, Smith HV. The effect of blueberry extracts on Giardia duodenalis viability and spontaneous excystation of Cryptosporidium parvum oocysts, in vitro. Methods. 2007;42(4):339-48.

260. Alzoreky NS, Nakahara K. Antibacterial activity of extracts from some edible plants commonly consumed in Asia. Int J Food Microbiol. 2003;80(3):223-30.

261. Elzaawely AA, Xuan TD, Tawata S. Antioxidant and antibacterial activities of Rumex japonicus HOUTT. Aerial parts. Biol Pharm Bull. 2005;28(12):2225-30.

262. Humeera N, Kamili AN, Bandh SA, Amin SU, Lone BA, Gousia N. Antimicrobial and antioxidant activities of alcoholic extracts of Rumex dentatus L. Microb Pathog. 2013;57:17-20.

263. Rouf AS, Islam MS, Rahman MT. Evaluation of antidiarrhoeal activity Rumex maritimus root. J Ethnopharmacol. 2003;84(2-3):307-10.

264. Vargas R, Perez S, Zavala MA, Chimal A. Inhibitory effect of Salix taxifolia extract on rat ileum contraction. Phytother Res. 1998;12:S51-2.

265. Khalil R, Li Z-G. Antimicrobial activity of essential oil of Salvia officinalis L. collected in Syria. Afr J Biotechnol. 2011;10(42):8397-402.

266. Piesova E, Makova Z, Levkut M, Faixova Z, Pistl J, Marcin A, Levkut M. The effects of sage extract feed supplementation on biochemical parameters, weight of internal organs and Salmonella counts in chickens. Res Vet Sci. 2012;93(3):1307-8.

267. Szaboova R, Laukova A, Chrastinova L, Simonova M, Strompfova V, Haviarova M, Placha I, Faix S, Vasilkova Z, Chrenkova M, et al. Experimental Application of Sage in Rabbit Husbandry. Acta Vet Brno. 2008;77(4):581-8.

268. Szaboova R, Laukova A, Chrastinova L, Strompfova V, Simonova MP, Vasilkova Z, Cobanova K, Placha I, Chrenkova M. Effect of combined administration of enterocin 4231 and sage in rabbits. Pol J Vet Sci. 2011;14(3):359-66.

269. Khan A, Najeeb Ur R, AlKharfy KM, Gilani A-H. Antidiarrheal and antispasmodic activities of Salvia officinalis are mediated through activation of $\mathrm{K}+$ channels. Bangladesh Journal of Pharmacology. 2011;6(2):111-6.

270. Marcin A, Laukova A, Mati R. Comparison of the effects of Enterococcus faecium and aromatic oils from sage and oregano on growth performance and diarrhoeal diseases of weaned pigs. Biologia. 2006;61(6):789-95.

271. Arjoon AV, Saylor CV, May M. In Vitro efficacy of antimicrobial extracts against the atypical ruminant pathogen Mycoplasma mycoides subsp. capri. BMC Complement Altern Med. 2012;12:169.

272. Zeman M, Nosal'ova V, Bobek P, Zakalova M, Cerna S. Changes of endogenous melatonin and protective effect of diet containing pleuran and extract of black elder in colonic inflammation in rats. Biologia. 2001;56(6):695-701.

273. Essawi T, Srour M. Screening of some Palestinian medicinal plants for antibacterial activity. J Ethnopharmacol. 2000;70(3):343-9.

274. Lisin G, Safiyev S, Craker LE: Antimicrobial activity of some essential oils. In: Second World Congress on Medicinal and Aromatic Plants for Human Welfare Wocmap-2: Pharmacognosy, Pharmacology, Phytomedicines, Toxicology. edn. Edited by Martino V, Caffini N, Lappa A, Schilcher H, Phillipson JD, Tchernitchin A, Debenedetti S, Acevedo C; 1999: 283-288.

275. Babaei M, Abarghoei ME, Ansari R, Vafaei AA, Taherian AA, Akhavan MM, Toussy G, Mousavi S. Antispasmodic effect of hydroalcoholic extract of Thymus vulgaris on the guinea-pig ileum. Nat Prod Res. 2008;22(13):1143-50.

276. Beer AM, Lukanov J, Sagorchev P. Effect of Thymol on the spontaneous contractile activity of the smooth muscles. Phytomedicine : international journal of phytotherapy and phytopharmacology. 2007;14(1):65-9.

277. Hagmueller W, Jugl-Chizzola M, Zitterl-Eglseer K, Gabler C, Spergser J, Chizzola R, Franz C. The use of Thymi Herba as feed additive $(0.1 \%, 0.5 \%$, $1.0 \%$ in weanling piglets with assessment of the shedding of haemolysing E. coli and the detection of thymol in the blood plasma. Berl Munch Tierarztl Wochenschr. 2006;119(1-2):50-4.

278. Jugl-Chizzola M, Spergser J, Schilcher F, Novak J, Bucher A, Gabler C, Hagmuller $W$, Zitterl-Eglseer K. Effects of Thymus vulgaris $L$. as feed additive in piglets and against haemolytic E-coli in vitro. Berl Munch Tierarztl Wochenschr. 2005; 118(11-12):495-501.

279. Placha I, Takacova J, Ryzner M, Cobanova K, Laukova A, Strompfova V, Venglovska $K$, Faix S. Effect of thyme essential oil and selenium on intestine integrity and antioxidant status of broilers. Br Poultry Sci. 2014;55(1):105-14.

280. Kokoska L, Polesny Z, Rada V, Nepovim A, Vanek T. Screening of some Siberian medicinal plants for antimicrobial activity. J Ethnopharmacol. 2002:82(1):51-3.

281. Stanciuc AM, Gaspar A, Moldovan L, Saviuc C, Popa M, Marutescu L. In vitro antimicrobial activity of Romanian medicinal plants hydroalcoholic extracts on planktonic and adhered cells. Roum Arch Microbiol Immunol. 201 1;70(1):11-4.

282. Erdogrul OT. Antibacterial activities of some plant extracts used in folk medicine. Pharm Biol. 2002;40(4):269-73.

283. Genc Z, Yarat A, Tunali-Akbay T, Sener G, Cetinel S, Pisiriciler R, Caliskan-Ak E, Altintas A, Demirci B. The effect of stinging nettle (Urtica dioica) seed oil on experimental colitis in rats. J Med Food. 2011;14(12):1554-61.

284. Konrad A, Mahler M, Arni S, Flogerzi B, Klingelhofer S, Seibold F. Ameliorative effect of IDS 30, a stinging nettle leaf extract, on chronic colitis. Int J Colorectal Dis. 2005;20(1):9-17.

285. Drozd J, Anuszewska E. Effects of bilberry fruit aqueous extract and selected antibiotics on immune response in mice. Acta Pol Pharm. 2009;66(2):181-5.

286. Graf D, Seifert S, Bub A, Frohling B, Dold S, Unger F, Rompp A, Watzl B. Anthocyanin-rich juice does not affect gut-associated immunity in Fischer rats. Mol Nutr Food Res. 2013;57(10):1753-61.

287. Jakesevic M, Xu J, Aaby K, Jeppsson B, Ahrne S, Molin G. Effects of bilberry (Vaccinium myrtillus) in combination with lactic acid bacteria on intestinal oxidative stress induced by ischemia-reperfusion in mouse. J Agric Food Chem. 2013;61(14):3468-78.

288. Feizpour A, Boskabady MH, Byrami G, Golamnezhad Z, Shafei MN. The effect of hydro-ethanolic extract of Achillea millefolium on muscarinic receptors of guinea pig tracheal smooth muscle. Indian J Pharmacol. 2013;45(1):13-7. 
289. Koushyar H, Koushyar MM, Byrami G, Feizpour A, Golamnezhad Z, Boskabady $\mathrm{MH}$. The Effect of Hydroethanol Extract of Achillea Millefolium on betaadrenoceptors of Guinea Pig Tracheal Smooth Muscle. Indian journal of pharmaceutical sciences. 2013;75(4):400-5.

290. Khan AU, Gilani AH. Blood pressure lowering, cardiovascular inhibitory and bronchodilatory actions of Achillea millefolium. Phytotherapy research : PTR. 2011;25(4):577-83.

291. Shin WJ, Lee KH, Park MH, Seong BL. Broad-spectrum antiviral effect of Agrimonia pilosa extract on influenza viruses. Microbiol Immunol. 2010; 54(1):11-9.

292. Fehri B, Ahmed MK, Aiache JM. The relaxant effect induced by Allium sativum $L$. bulb aqueous extract on rat isolated trachea. Pharmacogn Mag. 2011;7(25):14-8

293. Nosalova G, Sutovska M, Mokry J, Kardosova A, Capek P, Khan MTH. Efficacy of herbal substances according to cough reflex. Minerva Biotecnologica. 2005;17(3):141-52.

294. Sutovska M, Nosalova G, Franova S, Kardosova A. The antitussive activity of polysaccharides from Althaea officinalis I., var. Robusta, Arctium lappa L., var. Herkules, and Prunus persica L., Batsch. Bratisl Lek Listy. 2007; 108(2):93-9.

295. Sutovska M, Nosalova G, Sutovsky J, Franova S, Prisenznakova L, Capek P. Possible mechanisms of dose-dependent cough suppressive effect of Althaea officinalis rhamnogalacturonan in guinea pigs test system. Int J Biol Macromol. 2009;45(1):27-32.

296. Sutovska M, Capek P, Franova S, Joskova M, Sutovsky J, Marcinek J, Kalman M. Antitussive activity of Althaea officinalis L. polysaccharide rhamnogalacturonan and its changes in guinea pigs with ovalbumine-induced airways inflammation. Bratisl Lek Listy. 2011;112(12):670-5.

297. Yamada H, Ohashi K, Atsumi T, Okabe H, Shimizu T, Nishio S, Li XD, Kosuge K, Watanabe H, Hara Y. Effects of tea catechin inhalation on methicillinresistant Staphylococcus aureus in elderly patients in a hospital ward. J Hosp Infect. 2003;53(3):229-31.

298. Peng Q, Huang Y, Hou B, Hua D, Yao F, Qian Y. Green Tea Extract Weakens the Antibacterial Effect of Amoxicillin in Methicillin-resistant Staphylococcus Aureus Infected Mice. Phytother Res. 2010;24(1):141-5.

299. Kempe C, Gruning H, Stasche N, Hormann K. Icelandic moss for prevention and treatment of inflammation and dryness of the oral mucosa. LaryngoRhino-Otologie. 1997;76(3):186-8.

300. Karimi S, Mohammadi A, Dadras H. The effect of Echinacea purpurea and Sambucus nigra L. on H9N2 avian influenza virus in infected chicken embryo. Veterinarski Arhiv. 2014;84(2):153-65.

301. Sharma M, Schoop R, Hudson JB. Echinacea as an antiinflammatory agent: the influence of physiologically relevant parameters. Phytotherapy research : PTR. 2009;23(6):863-7.

302. Bany J, Siwicki AK, Zdanowska D, Sokolnicka I, Skopinska-Rozewska E, Kowalczyk M. Echinacea purpurea stimulates cellular immunity and antibacterial defence independently of the strain of mice. Pol J Vet Sci. 2003;6(3 Suppl):3-5

303. Fusco D, Liu X, Savage C, Taur Y, Xiao W, Kennelly E, Yuan J, Cassileth B, Salvatore M, Papanicolaou GA. Echinacea purpurea aerial extract alters course of influenza infection in mice. Vaccine. 2010;28(23):3956-62.

304. Lindenmuth GF, Lindenmuth EB. The efficacy of echinacea compound herbal tea preparation on the severity and duration of upper respiratory and flu symptoms: a randomized, double-blind placebo-controlled study. Journal of alternative and complementary medicine (New York, NY) 2000;6(4):327-34.

305. Grimm W, Muller HH. A randomized controlled trial of the effect of fluid extract of Echinacea purpurea on the incidence and severity of colds and respiratory infections. Am J Med. 1999;106(2):138-43.

306. Turner RB, Riker DK, Gangemi JD. Ineffectiveness of echinacea for prevention of experimental rhinovirus colds. Antimicrob Agents Chemother. 2000;44(6):1708-9.

307. Boskabady MH, Khatami A. Relaxant effect of Foeniculum vulgare on isolated guinea pig tracheal chains. Pharm Biol. 2003;41(3):211-5.

308. Boskabady MH, Khatami A, Nazari A. Possible mechanism(s) for relaxant effects of Foeniculum vulgare on guinea pig tracheal chains. Pharmazie. 2004;59(7):561-4.

309. Grienke U, Braun H, Seidel N, Kirchmair J, Richter M, Krumbholz A, von Grafenstein S, Liedl KR, Schmidtke M, Rollinger JM. Computer-Guided Approach to Access the Anti-influenza Activity of Licorice Constituents. J Nat Prod. 2014;77(3):563-70.
310. Boskabady MH, Ramazani-Assari M. Possible mechanism for the relaxant effect of Pimpinella anisum on guinea pig tracheal chains. Pharm Biol. 2004; 42(8):621-5.

311. Boskabady MH, Ramazani-Assari M. Relaxant effect of Pimpinella anisum on isolated guinea pig tracheal chains and its possible mechanism(s). J Ethnopharmacol. 2001;74(1):83-8.

312. Basbuelbuel G, Oezmen A, Biyik HH, Sen O. Antimitotic and antibacterial effects of the Primula veris L. flower extracts. Caryologia. 2008;61(1):88-91.

313. Rossi A, Serraino I, Dugo P, Di Paola R, Mondello L, Genovese T, Morabito D, Dugo G, Sautebin L, Caputi AP, et al. Protective effects of anthocyanins from blackberry in a rat model of acute lung inflammation. Free Radic Res. 2003; 37(8):891-900.

314. Getie M, Gebre-Mariam T, Rietz R, Hohne C, Huschka C, Schmidtke M, Abate A, Neubert RH. Evaluation of the anti-microbial and anti-inflammatory activities of the medicinal plants Dodonaea viscosa, Rumex nervosus and Rumex abyssinicus. Fitoterapia. 2003;74(1-2):139-43.

315. Orhan I, Deliorman-Orhan D, Ozcelik B. Antiviral activity and cytotoxicity of the lipophilic extracts of various edible plants and their fatty acids. Food Chem. 2009;115(2):701-5.

316. Hubbert M, Sievers H, Lehnfeld R, Kehrl W. Efficacy and tolerability of a spray with Salvia officinalis in the treatment of acute pharyngitis - a randomised, double-blind, placebo-controlled study with adaptive design and interim analysis. Eur J Med Res. 2006;11(1):20-6.

317. Zakay-Rones Z, Thom E, Wollan T, Wadstein J. Randomized study of the efficacy and safety of oral elderberry extract in the treatment of influenza A and B virus infections. J Int Med Res. 2004;32(2):132-40.

318. Iten F, Saller R, Abel G, Reichling J. Additive Antmicrobial Effects of the Active Components of the Essential Oil of Thymus vulgaris - Chemotype Carvacrol. Planta Med. 2009;75(11):1231-6.

319. Mullen KA, Lee AR, Lyman RL, Mason SE, Washburn SP, Anderson KL. Short communication: an in vitro assessment of the antibacterial activity of plantderived oils. J Dairy Sci. 2014;97(9):5587-91.

320. Meister A, Bernhardt G, Christoffel V, Buschauer A. Antispasmodic activity of Thymus vulgaris extract on the isolated guinea-pig trachea: Discrimination between drug and ethanol effects. Planta Med. 1999;65(6):512-6.

321. Wienkoetter N, Begrow F, Kinzinger U, Schierstedt D, Verspohl EJ. The effect of thyme extract on beta(2)-receptors and mucociliary clearance. Planta Med. 2007;73(7):629-35.

322. Turker AU, Usta C. Biological screening of some Turkish medicinal plant extracts for antimicrobial and toxicity activities. Nat Prod Res. 2008; 22(2):136-46.

323. Li ZY, Zhi HJ, Xue SY, Sun HF, Zhang FS, Jia JP, Xing J, Zhang LZ, Qin XM. Metabolomic profiling of the flower bud and rachis of Tussilago farfara with antitussive and expectorant effects on mice. J Ethnopharmacol. 2012;140(1):83-90.

324. Modarresi-Chahardehi A, Ibrahim D, Fariza-Sulaiman S, Mousavi L. Screening antimicrobial activity of various extracts of Urtica dioica. Rev Biol Trop. 2012; 60(4):1567-76.

325. Motamedi H, Seyyednejad SM, Bakhtiari A, Vafaei M. Introducing Urtica dioica, A Native Plant of Khuzestan, As an Antibacterial Medicinal Plant. Jundishapur journal of natural pharmaceutical products. 2014;9(4): e15904.

326. Kumaki Y, Wandersee MK, Smith AJ, Zhou Y, Simmons G, Nelson NM, Bailey KW, Vest ZG, Li JK, Chan PK, et al. Inhibition of severe acute respiratory syndrome coronavirus replication in a lethal SARS-CoV BALB/c mouse model by stinging nettle lectin, Urtica dioica agglutinin. Antiviral Res. 2011;90(1):22-32.

327. Sekizawa H, Ikuta K, Mizuta K, Takechi S, Suzutani T. Relationship between polyphenol content and anti-influenza viral effects of berries. J Sci Food Agric. 2013;93(9):2239-41.

328. Yassa N, Saeidnia S, Pirouzi R, Akbaripour M, Shafiee A. Three phenolic glycosides and immunological properties of Achillea millefolium from Iran, population of Golestan. Daru-Journal of Pharmaceutical Sciences. 2007; 15(1):49-52.

329. Benedek B, Kopp B, Melzig MF. Achillea millefolium L. s.I. - Is the antiinflammatory activity mediated by protease inhibition? J Ethnopharmacol. 2007:113(2):312-7.

330. Toghyani M, Tohidi M, Toghyani M, Gheisari A, Tabeidian SA. Evaluation of yarrow (Achillea millefolium) as a natural growth promoter in comparison with a probiotic supplement on performance, humoral immunity and blood metabolites of broiler chicks. Journal of Medicinal Plants Research. 2011; 5(13):2748-54 
331. Pires JM, Mendes FR, Negri G, Duarte-Almeida JM, Carlini EA. Antinociceptive peripheral effect of Achillea millefolium L. and Artemisia vulgaris L.: both plants known popularly by brand names of analgesic drugs. Phytotherapy research : PTR. 2009;23(2):212-9.

332. Ivanova D, Vankova D, Nashar M. Agrimonia eupatoria tea consumption in relation to markers of inflammation, oxidative status and lipid metabolism in healthy subjects. Arch Physiol Biochem. 2013;119(1):32-7.

333. Colic M, Vucevic D, Kilibarda V, Radicevic N, Savic M. Modulatory effects of garlic extracts on proliferation of T-lymphocytes in vitro stimulated with concanavalin A. Phytomedicine : international journal of phytotherapy and phytopharmacology. 2002;9(2):117-24.

334. Dorhoi A, Dobrean V, Zahan M, Virag P. Modulatory effects of several herbal extracts on avian peripheral blood cell immune responses. Phytother Res. 2006;20(5):352-8.

335. Mirabeau TY, Samson ES. Effect of Allium cepa and Allium sativum on some immunological cells in rats. Afr J Tradit Complement Altern Med. 2012; 9(3):374-9.

336. Chattopadhyay C, Chakrabarti N, Chatterjee M, Mukherjee S, Sarkar K, Chaudhuri AR. Black tea (Camellia sinensis) decoction shows immunomodulatory properties on an experimental animal model and in human peripheral mononuclear cells. Pharmacognosy research. 2012;4(1):15-21.

337. Hendricks R, Pool EJ. The in vitro effects of rooibos and black tea on immune pathways. J Immunoassay Immunochem. 2010;31(2):169-80.

338. Chatterjee $P$, Chandra S, Dey P, Bhattacharya S. Evaluation of antiinflammatory effects of green tea and black tea: A comparative in vitro study. Journal of advanced pharmaceutical technology \& research. 2012;3(2): $136-8$.

339. Wilasrusmee C, Siddiqui J, Bruch D, Wilasrusmee S, Kittur S, Kittur DS. In vitro immunomodulatory effects of herbal products. Am Surg. 2002;68(10):860-4.

340. Koeberle A, Bauer J, Verhoff M, Hoffmann M, Northoff H, Werz O. Green tea epigallocatechin-3-gallate inhibits microsomal prostaglandin E(2) synthase-1. Biochem Biophys Res Commun. 2009;388(2):350-4.

341. Neyestani TR, Gharavi A, Kalayi A. Selective effects of tea extract and its phenolic compounds on human peripheral blood mononuclear cell cytokine secretions. Int J Food Sci Nutr. 2009;60 Suppl 1:79-88.

342. Nicod N, Chiva-Blanch G, Giordano E, Davalos A, Parker RS, Visioli F. Green tea, cocoa, and red wine polyphenols moderately modulate intestinal inflammation and do not increase high-density lipoprotein (HDL) production. J Agric Food Chem. 2014;62(10):2228-32.

343. Pajonk F, Riedisser A, Henke M, McBride WH, Fiebich B. The effects of tea extracts on proinflammatory signaling. BMC Med. 2006;4:28.

344. Pomari E, Stefanon B, Colitti M. Effect of plant extracts on $\mathrm{H}_{2} \mathrm{O} 2$-induced inflammatory gene expression in macrophages. J Inflamm Res. 2014:7:103-12.

345. Singh R, Ahmed S, Islam N, Goldberg VM, Haqqi TM. Epigallocatechin-3-gallate inhibits interleukin-1 beta-induced expression of nitric oxide synthase and production of nitric oxide in human chondrocytes: suppression of nuclear factor kappaB activation by degradation of the inhibitor of nuclear factor kappaB. Arthritis Rheum. 2002;46(8):2079-86.

346. Takano K, Nakaima K, Nitta M, Shibata F, Nakagawa H. Inhibitory effect of (-)-epigallocatechin 3-gallate, a polyphenol of green tea, on neutrophil chemotaxis in vitro and in vivo. J Agric Food Chem. 2004;52(14):4571-6.

347. Tomita M, Irwin Kl, Xie ZJ, Santoro TJ. Tea pigments inhibit the production of type $1(\mathrm{~T}-\mathrm{H} 1)$ and type $2(\mathrm{~T}-\mathrm{H} 2)$ helper T cell cytokines in CD4(+) T cells. Phytother Res. 2002;16(1):36-42.

348. Wang H, Shi S, Gu X, Zhu C, Wei G, Wang H, Bao B, Fan H, Zhang W, Duan J, et al. Homogalacturonans from preinfused green tea: structural characterization and anticomplementary activity of their sulfated derivatives. J Agric Food Chem. 2013;61(46):10971-80.

349. Monobe M, Ema K, Tokuda Y, Maeda-Yamamoto M. Effect on the epigallocatechin gallate/epigallocatechin ratio in a green tea (Camellia sinensis L.) extract of different extraction temperatures and its effect on IgA production in mice. Biosci, Biotechnol, Biochem. 2010;74(12):2501-3.

350. Li W, Ashok M, Li J, Yang H, Sama AE, Wang H. A major ingredient of green tea rescues mice from lethal sepsis partly by inhibiting HMGB1. PLoS One. 2007;2(11):e1153.

351. Arzi A, Ghorbanzadeh B, Nazari Khorasgani Z. Antinociceptive Effect of Hydroalcoholic Extract of Iranian Green tea in the Formalin Test in Rats. Jundishapur journal of natural pharmaceutical products. 2013;8(1):10-4.

352. Ingolfsdottir $\mathrm{K}$, Jurcic K, Fischer B, Wagner $\mathrm{H}$. Immunologically active polysaccharide from Cetraria islandica. Planta Med. 1994;60(6):527-31.
353. Olafsdottir ES, Ingolfsdottir K, Barsett H, Paulsen BS, Jurcic K, Wagner H. Immunologically active (1->3)-(1->4)-alpha-D-glucan from Cetraria islandica. Phytomedicine 1999;6(1):33-39.

354. Freysdottir J, Omarsdottir S, Ingolfsdottir K, Vikingsson A, Olafsdottir ES. In vitro and in vivo immunomodulating effects of traditionally prepared extract and purified compounds from Cetraria islandica. Int Immunopharmacol. 2008;8(3):423-30.

355. Bauer VR, Jurcic K, Puhlmann J, Wagner H. Immunologic in vivo and in vitro studies on Echinacea extracts. Arzneimittelforschung. 1988;38(2):276-81.

356. Yin SY, Wang WH, Wang BX, Aravindaram K, Hwang PI, Wu HM, Yang NS. Stimulatory effect of Echinacea purpurea extract on the trafficking activity of mouse dendritic cells: revealed by genomic and proteomic analyses. BMC Genomics. 2010;11:612.

357. Bodinet C, Lindequist U, Teuscher E, Freudenstein J. Influence of peroral application of a herbal immunomodulator on the antibody production of Peyer's patches cells. Arzneimittelforschung. 2004;54(2):114-8.

358. Classen B, Thude S, Blaschek W, Wack M, Bodinet C. Immunomodulatory effects of arabinogalactan-proteins from Baptisia and Echinacea. Phytomedicine international journal of phytotherapy and phytopharmacology. 2006; 13(9-10):688-94.

359. Hwang SA, Dasgupta A, Actor JK. Cytokine production by non-adherent mouse splenocyte cultures to Echinacea extracts. Clinica chimica acta; international journal of clinical chemistry. 2004;343(1-2):161-6.

360. Matthias A, Banbury L, Bone KM, Leach DN, Lehmann RP. Echinacea alkylamides modulate induced immune responses in T-cells. Fitoterapia. 2008;79(1):53-8

361. Pugh ND, Balachandran P, Lata H, Dayan FE, Joshi V, Bedir E, Makino T, Moraes R, Khan I, Pasco DS. Melanin: dietary mucosal immune modulator from Echinacea and other botanical supplements. Int Immunopharmacol. 2005;5(4):637-47.

362. Randolph RK, Gellenbeck K, Stonebrook K, Brovelli E, Qian Y, Bankaitis-Davis $D$, Cheronis J. Regulation of human immune gene expression as influenced by a commercial blended Echinacea product: preliminary studies. Exp Biol Med. 2003:228(9):1051-6.

363. Rininger JA, Kickner S, Chigurupati P, McLean A, Franck Z. Immunopharmacological activity of Echinacea preparations following simulated digestion on murine macrophages and human peripheral blood mononuclear cells. J Leukoc Biol. 2000;68(4):503-10.

364. Senchina DS, McCann DA, Asp JM, Johnson JA, Cunnick JE, Kaiser MS, Kohut ML. Changes in immunomodulatory properties of Echinacea spp. root infusions and tinctures stored at 4 degrees $C$ for four days. Clinica chimica acta; international journal of clinical chemistry. 2005;355(1-2):67-82.

365. Wagner $H$, Jurcic K. Immunological studies of Revitonil((R)), a phytopharmaceutical containing Echinacea purpurea and Glycyrrhiza glabra root extract. Phytomedicine : international journal of phytotherapy and phytopharmacology. 2002;9(5):390-7.

366. Wang CY, Chiao MT, Yen PJ, Huang WC, Hou CC, Chien SC, Yeh KC, Yang WC, Shyur LF, Yang NS. Modulatory effects of Echinacea purpurea extracts on human dendritic cells: a cell- and gene-based study. Genomics. 2006; 88(6):801-8

367. Wang CY, Staniforth V, Chiao MT, Hou CC, Wu HM, Yeh KC, Chen CH, Hwang PI, Wen TN, Shyur LF, et al. Genomics and proteomics of immune modulatory effects of a butanol fraction of echinacea purpurea in human dendritic cells. BMC Genomics. 2008;9:479.

368. Wildfeuer A, Mayerhofer D. Study of the influence of phytopreparations on the cellular function of body defense. Arzneimittel-Forschung/Drug Research. 1994;44-1(3):361-6.

369. Matthias A, Banbury L, Stevenson LM, Bone KM, Leach DN, Lehmann RP. Alkylamides from echinacea modulate induced immune responses in macrophages. Immunol Invest. 2007;36(2):117-30.

370. Cech NB, Kandhi V, Davis JM, Hamilton A, Eads D, Laster SM. Echinacea and its alkylamides: effects on the influenza A-induced secretion of cytokines, chemokines, and PGE(2) from RAW 264.7 macrophage-like cells. Int Immunopharmacol. 2010;10(10):1268-78.

371. Chicca A, Raduner S, Pellati F, Strompen T, Altmann KH, Schoop R, Gertsch J. Synergistic immunomopharmacological effects of $\mathrm{N}$-alkylamides in Echinacea purpurea herbal extracts. Int Immunopharmacol. 2009;9(7-8):850-8.

372. Dong GC, Chuang PH, Chang KC, Jan PS, Hwang PI, Wu HB, Yi M, Zhou HX, Chen HM. Blocking effect of an immuno-suppressive agent, cynarin, on CD28 of T-cell receptor. Pharm Res. 2009;26(2):375-81. 
373. Sharma SM, Anderson M, Schoop SR, Hudson JB. Bactericidal and antiinflammatory properties of a standardized Echinacea extract (Echinaforce (R)): Dual actions against respiratory bacteria. Phytomedicine : international journal of phytotherapy and phytopharmacology. 2010;17(8-9):563-8.

374. Zhai Z, Solco A, Wu L, Wurtele ES, Kohut ML, Murphy PA, Cunnick JE. Echinacea increases arginase activity and has anti-inflammatory properties in RAW 264.7 macrophage cells, indicative of alternative macrophage activation. J Ethnopharmacol. 2009;122(1):76-85.

375. Freier DO, Wright K, Klein K, Voll D, Dabiri K, Cosulich K, George R. Enhancement of the humoral immune response by Echinacea purpurea in female Swiss mice. Immunopharmacol Immunotoxicol. 2003;25(4):551-60.

376. Steinmüller C, Roesler J, Grottrup E, Franke G, Wagner H, Lohmann-Matthes ML. Polysaccharides isolated from plant cell cultures of Echinacea purpurea enhance the resistance of immunosuppressed mice against systemic infections with Candida albicans and Listeria monocytogenes. Int J Immunopharmacol. 1993;15(5):605-14.

377. Roesler J, Emmendorffer A, Steinmuller C, Luettig B, Wagner H, LohmannMatthes ML. Application of purified polysaccharides from cell cultures of the plant Echinacea purpurea to test subjects mediates activation of the phagocyte system. Int J Immunopharmacol. 1991;13(7):931-41.

378. Skopinska-Rozewska E, Sokolnicka I, Siwicki AK, Stankiewicz W, Dabrowski MP, Buchwald W, Krajewska-Patan A, Mielcarek S, Mscisz A, Furmanowa M. Dose-dependent in vivo effect of Rhodiola and Echinacea on the mitogeninduced lymphocyte proliferation in mice. Pol J Vet Sci. 2011;14(2):265-72.

379. Uluisik D, Keskin E. Effects of ginseng and echinacea on cytokine mRNA expression in rats. Sci World J. 2012;2012:942025

380. Zwickey H, Brush J, lacullo CM, Connelly E, Gregory WL, Soumyanath A, Buresh R. The effect of Echinacea purpurea, Astragalus membranaceus and Glycyrrhiza glabra on CD25 expression in humans: a pilot study. Phytotherapy research : PTR. 2007:21(11):1109-12.

381. O'Neil J, Hughes S, Lourie A, Zweifler J. Efects of echinacea on the frequency of upper respiratory tract symptoms: a randomized, double-blind, placebocontrolled trial. Ann Allergy Asthma Immunol. 2008;100(4):384-8.

382. Schwarz E, Parlesak A, Henneicke-von Zepelin HH, Bode JC, Bode C. Effect of oral administration of freshly pressed juice of Echinacea purpurea on the number of various subpopulations of B- and T-lymphocytes in healthy volunteers: results of a double-blind, placebo-controlled cross-over study. Phytomedicine : international journal of phytotherapy and phytopharmacology. 2005;12(9):625-31.

383. Schulten B, Bulitta M, Ballering-Bruhl B, Koster U, Schafer M. Efficacy of Echinacea purpurea in patients with a common cold - A placebo-controlled, randomised, double-blind clinical trial. Arzneimittel-Forschung-Drug Research. 2001; 51(7):563-8

384. Taylor JA, Weber W, Standish L, Quinn H, Goesling J, McGann M, Calabrese C. Efficacy and safety of echinacea in treating upper respiratory tract infections in children: a randomized controlled trial. Jama. 2003;290(21):2824-30.

385. Kaileh M, Vanden Berghe W, Boone E, Essawi T, Haegeman G. Screening of indigenous Palestinian medicinal plants for potential anti-inflammatory and cytotoxic activity. J Ethnopharmacol. 2007;113(3):510-6.

386. Choi EM, Hwang JK. Antiinflammatory, analgesic and antioxidant activities of the fruit of Foeniculum vulgare. Fitoterapia. 2004;75(6):557-65.

387. Tanira MOM, Shah AH, Mohsin A, Ageel AM, Qureshi S. Pharmacological and toxicological investigations on Foeniculum vulgare dried fruit extract in experimental animals. Phytother Res. 1996;10(1):33-6.

388. Zendehdel M, Taati M, Amoozad M, Hamidi F. Antinociceptive effect of the aqueous extract obtained from Foeniculum vulgare in mice: the role of histamine $\mathrm{H}-1$ and $\mathrm{H}-2$ receptors. Iranian Journal of Veterinary Research. 2012:13(2):100-6.

389. Bordbar N, Karimi MH, Amirghofran Z. The effect of glycyrrhizin on maturation and T cell stimulating activity of dendritic cells. Cell Immunol. 2012;280(1):44-9.

390. Cheel J, Van Antwerpen P, Tumova L, Onofre G, Vokurkova D, ZouaouiBoudjeltia K, Vanhaeverbeek M, Neve J. Free radical-scavenging, antioxidant and immunostimulating effects of a licorice infusion (Glycyrrhiza glabra L.). Food Chem. 2010;122(3):508-17.

391. Chen $\mathrm{CL}$, Zhang DD. Anti-inflammatory effects of 81 chinese herb extracts and their correlation with the characteristics of traditional chinese medicine. Evidence-based complementary and alternative medicine : eCAM. 2014; 2014:985176.

392. Herold A, Cremer L, Calugaru A, Tamas V, lonescu F, Manea S, Szegli G. Hydroalcoholic plant extracts with anti-inflammatory activity. Roum Arch Microbiol Immunol. 2003;62(1-2):117-29.
393. Brush J, Mendenhall E, Guggenheim A, Chan T, Connelly E, Soumyanath A, Buresh $\mathrm{R}$, Barrett $\mathrm{R}$, Zwickey $\mathrm{H}$. The effect of Echinacea purpurea, Astragalus membranaceus and Glycyrrhiza glabra on CD69 expression and immune cell activation in humans. Phytotherapy research : PTR. 2006;20(8):687-95.

394. Mohan M, Austin A, Gulecha VS, Aurangabadkar VM, Balaraman R, Thirugnanasampathan S. Analgesic and anti-inflammatory activity of a polyherbal formulation (PHFAROGH). Orient Pharm Exp Med. 2009;9(3):232-7.

395. Kaithwas G, Majumdar DK. Effect of L. usitatissimum (Flaxseed/Linseed) Fixed Oil against Distinct Phases of Inflammation. ISRN inflammation. 2013:2013:735158

396. Vineyard KR, Warren LK, Kivipelto J. Effect of dietary omega-3 fatty acid source on plasma and red blood cell membrane composition and immune function in yearling horses. J Anim Sci. 2010;88(1):248-57.

397. Kaithwas G, Mukherjee A, Chaurasia AK, Majumdar DK. Anti-inflammatory, analgesic and antipyretic activities of Linum usitatissimum L. (flaxseed/ linseed) fixed oil. Indian J Exp Biol. 2011;49(12):932-8.

398. Singh S, Nair V, Jain S, Gupta YK. Evaluation of anti-inflammatory activity of plant lipids containing alpha-linolenic acid. Indian J Exp Biol. 2008; 46(6):453-6.

399. Ferreira Martins CA, Weffort-Santos AM, Gasparetto JC, Leal Badaro Trindade AC, Otuki MF, Pontarolo R. Malva sylvestris L. extract suppresses desferrioxamineinduced PGE(2) and PGD(2) release in differentiated U937 cells: the development and validation of an LC-MS/MS method for prostaglandin quantification. Biomed Chromatogr. 2014;28(7):986-93.

400. El Ghaoui WB, Ghanem EB, Chedid LA, Abdelnoor AM. The effects of Alcea rosea L., Malva sylvestris L. and Salvia libanotica L. water extracts on the production of anti-egg albumin antibodies, interleukin-4, gamma interferon and interleukin-12 in BALB/C mice. Phytotherapy research : PTR. 2008; 22(12):1599-604.

401. Esteves PF, Sato A, Esquibel MA, de Campos-Buzzi F, Meira AV, CechinelFilho V. Antinociceptive Activity of Malva sylvestris L. Lat Am J Pharm. 2009; 28(3):454-6.

402. Prudente AS, Loddi AM, Duarte MR, Santos AR, Pochapski MT, Pizzolatti MG, Hayashi SS, Campos FR, Pontarolo R, Santos FA, et al. Pre-clinical antiinflammatory aspects of a cuisine and medicinal millennial herb: Malva sylvestris L. Food and chemical toxicology : an international journal published for the British Industrial Biological Research Association. 2013;58:324-31.

403. Amirghofran Z, Azadbakht M, Karimi MH. Evaluation of the immunomodulatory effects of five herbal plants. J Ethnopharmacol. 2000;72(1-2):167-72.

404. Bhaskaran N, Shukla S, Srivastava JK, Gupta S. Chamomile: an anti-inflammatory agent inhibits inducible nitric oxide synthase expression by blocking RelA/p65 activity. Int J Mol Med. 2010;26(6):935-40.

405. Presibella MM, Santos CAM, Weffort-Santos AM. In vitro antichemotactic activity of Chamomilla recutita hydroethanol extract. Pharm Biol. 2007; 45(2):124-30

406. Safayhi H, Sabieraj J, Sailer ER, Ammon HP. Chamazulene: an antioxidanttype inhibitor of leukotriene B4 formation. Planta Med. 1994;60(5):410-3.

407. Srivastava JK, Pandey M, Gupta S. Chamomile, a novel and selective COX-2 inhibitor with anti-inflammatory activity. Life Sci. 2009;85(19-20):663-9.

408. Ghonime M, Eldomany R, Abdelaziz A, Soliman H. Evaluation of immunomodulatory effect of three herbal plants growing in Egypt. Immunopharmacol Immunotoxicol. 2011;33(1):141-5.

409. de Souza Reis LS, Frazatti-Gallina NM, de Lima PR, Giuffrida R, Albas A, Oba E, Pardo PE. Efficiency of Matricaria chamomilla $\mathrm{CH} 12$ and number of doses of rabies vaccine on the humoral immune response in cattle. J Vet Sci. 2008;9(4):433-5.

410. Rocha NF, Rios ER, Carvalho AM, Cerqueira GS, Lopes Ade A, Leal LK, Dias ML, de Sousa DP, de Sousa FC. Anti-nociceptive and anti-inflammatory activities of (-)-alpha-bisabolol in rodents. Naunyn Schmiedebergs Arch Pharmacol. 2011;384(6):525-33.

411. Smolinski AT, Pestka JJ. Modulation of lipopolysaccharide-induced proinflammatory cytokine production in vitro and in vivo by the herbal constituents apigenin (chamomile), ginsenoside $\mathrm{Rb}(1)$ (ginseng) and parthenolide (feverfew). Food and chemical toxicology : an international journal published for the British Industrial Biological Research Association. 2003;41(10):1381-90.

412. Tomic M, Popovic V, Petrovic S, Stepanovic-Petrovic R, Micov A, PavlovicDrobac M, Couladis M. Antihyperalgesic and antiedematous activities of bisabolol-oxides-rich matricaria oil in a rat model of inflammation. Phytotherapy research : PTR. 2014;28(5):759-66. 
413. Gobel H, Fresenius J, Heinze A, Dworschak M, Soyka D. Effectiveness of Oleum menthae piperitae and paracetamol in therapy of headache of the tension type. Nervenarzt. 1996;67(8):672-81.

414. Ocana-Fuentes A, Arranz-Gutierrez E, Senorans FJ, Reglero G. Supercritical fluid extraction of oregano (Origanum vulgare) essentials oils: antiinflammatory properties based on cytokine response on THP-1 macrophages. Food and chemical toxicology : an international journal published for the British Industrial Biological Research Association. 2010;48(6):1568-75.

415. Szaboova R, Laukova A, Lu C, Strompfova V, Simonova MP, Placha I, Vasilkova Z, Chrenkova M, Faix S. Beneficial effect of plant extracts in rabbit husbandry. Acta Vet Brno. 2012;81(3):245-50.

416. Walter BM, Bilkei G. Immunostimulatory effect of dietary oregano etheric oils on lymphocytes from growth-retarded, low-weight growing-finishing pigs and productivity. Tijdschr Diergeneeskd. 2004;129(6):178-81.

417. Cavalcante Melo FH, Rios ER, Rocha NF, Cito Mdo C, Fernandes ML, de Sousa DP, de Vasconcelos SM, de Sousa FC. Antinociceptive activity of carvacrol (5-isopropyl-2-methylphenol) in mice. J Pharm Pharmacol. 2012;64(12):1722-9.

418. Khaki MRA, Pahlavan Y, Sepehri G, Sheibani V, Pahlavan B. Antinociceptive Effect of Aqueous Extract of Origanum vulgare L. in Male Rats: Possible Involvement of the GABAergic System. Iranian Journal of Pharmaceutical Research. 2013;12(2):407-13.

419. Pahlavan Y, Sepehri G, Sheibani V, Khaki MA, Gojazadeh M, Pahlavan B, Pahlavan F. Study the Antinociceptive Effect of Intracerebroventricular Injection of Aqueous Extract of Origanum Vulgare Leaves in Rat: Possible Involvement of Opioid System. Iranian Journal of Basic Medical Sciences. 2013;16(10):1109-13.

420. Stelter K, Frahm J, Paulsen J, Berk A, Kleinwachter M, Selmar D, Danicke S. Effects of oregano on performance and immunmodulating factors in weaned piglets. Arch Anim Nutr. 2013;67(6):461-76.

421. Conforti F, Tundis R, Marrelli M, Menichini F, Statti GA, De Cindio B, Menichini F, Houghton PJ. Protective effect of Pimpinella anisoides ethanolic extract and its constituents on oxidative damage and its inhibition of nitric oxide in lipopolysaccharide-stimulated RAW 264.7 macrophages. J Med Food. 2010;13(1):137-41.

422. Mahmood MS, Hussain I, Ahmad MF, Khan A, Abbas RZ, Rafiq A. Immunomodulatory effects of Pimpinella anisum L. (Aniseed) in Broiler Chicks against Newcastle Disease and Infectious Bursal Disease Viruses. Boletin Latinoamericano Y Del Caribe De Plantas Medicinales Y Aromaticas. 2014;13(5):458-65.

423. Durrani FR, Sultan A, Ahmed S, Chand N, Khattak FM, Durrani Z. Efficacy of aniseed extract as immune stimulant and growth promoter in broiler chicks. Pakistan journal of biological sciences: PJBS. 2007;10(20):3718-21.

424. Marchesan M, Paper DH, Hose S, Franz G. Investigation of the antiinflammatory activity of liquid extracts of Plantago lanceolata L. Phytother Res. 1998;12:S33-4.

425. Vigo E, Cepeda A, Gualillo O, Perez-Fernandez R. In-vitro anti-inflammatory activity of Pinus sylvestris and Plantago lanceolata extracts: effect on inducible NOS, COX-1, COX-2 and their products in J774A.1 murine macrophages. J Pharm Pharmacol. 2005;57(3):383-91.

426. Tunon $\mathrm{H}$, Olavsdotter C, Bohlin L. Evaluation of anti-inflammatory activity of some Swedish medicinal plants. Inhibition of prostaglandin biosynthesis and PAF-induced exocytosis. J Ethnopharmacol. 1995;48(2):61-76.

427. Cuevas-Rodriguez EO, Dia VP, Yousef GG, Garcia-Saucedo PA, Lopez-Medina J, Paredes-Lopez O, Gonzalez De Mejia E, Ann Lila M. Inhibition of Proinflammatory Responses and Antioxidant Capacity of Mexican Blackberry (Rubus spp.) Extracts. J Agric Food Chem. 2010;58(17):9542-8.

428. Dai J, Patel JD, Mumper RJ. Characterization of blackberry extract and its antiproliferative and anti-inflammatory properties. J Med Food. 2007;10(2):258-65.

429. Denev P, Kratchanova M, Ciz M, Lojek A, Vasicek O, Blazheva D, Nedelcheva P, Vojtek L, Hyrsl P. Antioxidant, antimicrobial and neutrophil-modulating activities of herb extracts. Acta Biochim Pol. 2014;61(2):359-67.

430. Nasef NA, Mehta S, Murray P, Marlow G, Ferguson LR. Anti-inflammatory activity of fruit fractions in vitro, mediated through toll-like receptor 4 and 2 in the context of inflammatory bowel disease. Nutrients. 2014;6(11):5265-79.

431. Lee MJ, Song HJ, Jeong JY, Park SY, Sohn UD. Anti-Oxidative and AntiInflammatory Effects of QGC in Cultured Feline Esophageal Epithelial Cells. The Korean journal of physiology \& pharmacology : official journal of the Korean Physiological Society and the Korean Society of Pharmacology. 2013;17(1):81-7.
432. Suleyman H, Demirezer LO, Kuruuzum A, Banoglu ZN, Gocer F, Ozbakir G, Gepdiremen A. Antiinflammatory effect of the aqueous extract from Rumex patientia L. roots. J Ethnopharmacol. 1999;65(2):141-8.

433. Suleyman $H$, Demirezer LO, Kuruuzum-Uz A. Analgesic and antipyretic activities of Rumex patientia extract on mice and rabbits. Pharmazie. 2001;56(10):815-7.

434. Mekonnen T, Urga K, Engidawork E. Evaluation of the diuretic and analgesic activities of the rhizomes of Rumex abyssinicus Jacq in mice. J Ethnopharmacol. 2010;127(2):433-9.

435. Bonaterra GA, Heinrich EU, Kelber O, Weiser D, Metz J, Kinscherf R. Antiinflammatory effects of the willow bark extract STW 33-I (Proaktiv((R))) in LPS-activated human monocytes and differentiated macrophages. Phytomedicine : international journal of phytotherapy and phytopharmacology. 2010;17(14):1106-13.

436. Farinacci M, Colitti M, Sgorlon S, Stefanon B. Immunomodulatory activity of plant residues on ovine neutrophils. Vet Immunol Immunopathol. 2008; 126(1-2):54-63.

437. Fiebich BL, Chrubasik S. Effects of an ethanolic Salix extract on the release of selected inflammatory mediators in vitro. Phytomedicine: international journal of phytotherapy and phytopharmacology. 2004; 11(2-3):135-8.

438. Khayyal MT, El-Ghazaly MA, Abdallah DM, Okpanyi SN, Kelber O, Weiser D. Mechanisms involved in the anti-inflammatory effect of a standardized willow bark extract. Arzneimittel-Forschung-Drug Research. 2005;55(11):677-87.

439. Szaboova R, Chrastinova L, Laukova A, Strompfova V, Simonova MP, Vasilkova Z, Placha I, Cobanova K, Chrenkova M. Effect of combinative administration of bacteriocin-producing and probiotic strain Enterococcus faecium CCM 4231 and sage plant extract on rabbits. Afr J Microbiol Res. 2012;6(23):4868-73.

440. Ryzner M, Takacova J, Cobanova K, Placha I, Venglovska K, Faix S. Effect of dietary Salvia officinalis essential oil and sodium selenite supplementation on antioxidative status and blood phagocytic activity in broiler chickens. Acta Vet Brno. 2013;82(1):43-8.

441. Carrasco FR, Schmidt G, Romero AL, Sartoretto JL, Caparroz-Assef SM, Bersani-Amado CA, Cuman RK. Immunomodulatory activity of Zingiber officinale Roscoe, Salvia officinalis L. and Syzygium aromaticum L. essential oils: evidence for humor- and cell-mediated responses. J Pharm Pharmacol. 2009;61(7):961-7.

442. Alves Rodrigues MR, Sales Kanazawa LK, Neves TL M d, da Silva CF, Horst H, Pizzolatti MG, Soares Santos AR, Baggio CH, de Paula Werner MF. Antinociceptive and anti-inflammatory potential of extract and isolated compounds from the leaves of Salvia officinalis in mice. J Ethnopharmacol. 2012;139(2):519-26.

443. Qnais EY, Abu-Dieyeh M, Abdulla FA, Abdalla SS. The antinociceptive and anti-inflammatory effects of Salvia officinalis leaf aqueous and butanol extracts. Pharm Biol. 2010;48(10):1149-56.

444. Juhas S, Cikos S, Czikkova S, Vesela J, Ilkova G, Hajek T, Domaracka K, Domaracky M, Bujnakova D, Rehak P, et al. Effects of borneol and thymoquinone on TNBSinduced colitis in mice. Folia Biol. 2008;54(1):1-7.

445. Oniga I, Parvu AE, Toiu A, Benedec D. Effects of Salvia officinalis L. extract on experimental acute inflammation. Rev Med Chir Soc Med Nat lasi. 2007; $111(1): 290-4$.

446. Gorudko IV, Timoshenko AV. Effect of signaling inhibitors on the release of lysozyme from human neutrophils activated by Sambucus nigra agglutinin. Biochemistry Biokhimiia. 2000;65(8):940-5.

447. Modaresi M. A Comparative Analysis of the Effects of Garlic, Elderberry and Black Seed Extract on the Immune System in Mice. J Anim Vet Adv. 2012; $11(4): 458-61$

448. Amirghofran Z, Hashemzadeh R, Javidnia K, Golmoghaddam H, Esmaeilbeig A. In vitro immunomodulatory effects of extracts from three plants of the Labiatae family and isolation of the active compound(s). J Immunotoxicol. 2011;8(4):265-73.

449. Fachini-Queiroz FC, Kummer R, Estevao-Silva CF, de Barros Carvalho MD, Cunha JM, Grespan R, Bersani-Amado CA, Nakamura Cuman RK. Effects of Thymol and Carvacrol, Constituents of Thymus vulgaris L. Essential Oil, on the Inflammatory Response. Evidence-Based Complementary and Alternative Medicine 2012.

450. Ocana A, Reglero G. Effects of Thyme Extract Oils (from Thymus vulgaris, Thymus zygis, and Thymus hyemalis) on Cytokine Production and Gene Expression of oxLDL-Stimulated THP-1-Macrophages. J Obes. 2012;2012: 104706. 
451. Najafi P, Torki M. Performance, Blood Metabolites and Immunocompetaence of Broiler Chicks Fed Diets Included Essentioal Oils of Medicinal Herbs. J Anim Vet Adv. 2010;9(7):1164-8.

452. Taherian AA, Babaei M, Vafaei AA, Jarrahi M, Jadidi M, Sadeghi $H$. Antinociceptive effects of hydroalcoholic extract of Thymus vulgaris. Pak J Pharm Sci. 2009;22(1):83-9.

453. Hwangbo C, Lee HS, Park J, Choe J, Lee J-H. The anti-inflammatory effect of tussilagone, from Tussilago farfara, is mediated by the induction of heme oxygenase-1 in murine macrophages. Int Immunopharmacol. 2009;9(13-14):1578-84.

454. Akbay P, Basaran AA, Undeger U, Basaran N. In vitro immunomodulatory activity of flavonoid glycosides from Urtica dioica L. Phytotherapy research : PTR. 2003;17(1):34-7.

455. Basaran AA, Ceritoglu I, Undeger U, Basaran N. Immunomodulatory activities of some Turkish medicinal plants. Phytother Res. 1997;1 1(8):609-11.

456. Daoudi A, Aarab L, Abdel-Sattar E. Screening of immunomodulatory activity of total and protein extracts of some Moroccan medicinal plants. Toxicol Ind Health. 2013;29(3):245-53.

457. Johnson TA, Sohn J, Inman WD, Bjeldanes LF, Rayburn K. Lipophilic stinging nettle extracts possess potent anti-inflammatory activity, are not cytotoxic and may be superior to traditional tinctures for treating inflammatory disorders. Phytomedicine : international journal of phytotherapy and phytopharmacology. 2013;20(2):143-7.

458. Bolfa P, Catoi C, Gal A, Taulescu M, Fit N, Nadas G, Niculae M, Tamas M, Cuc C, Spinu M. Screening of five alcoholic plants extracts effects on the immune status of Romanian EIAV infected horses. Romanian Biotechnological Letters. 2011;16(6):6730-9.

459. Dana SC, Spinu M, Brudasca F, Opris A, Duca G: Alcoholic nettle extraction influences phagocytosis and body mass in broiler chickens. In: Bulletin of the University of Agricultural Sciences and Veterinary Medicine, Vol 61: VETERINARY MEDICINE. Volume 61, edn. Edited by Marghitas LA; 2004: 233-236.

460. Hajhashemi V, Klooshani V. Antinociceptive and anti-inflammatory effects of Urtica dioica leaf extract in animal models. Avicenna journal of phytomedicine. 2013;3(2):193-200.

461. Sautebin L, Rossi A, Serraino I, Dugo P, Di Paola R, Mondello L, Genovese T, (Britti D, Peli A, Dugo G, et al. Effect of anthocyanins contained in a blackberry extract on the circulatory failure and multiple organ dysfunction caused by endotoxin in the rat. Planta Med. 2004;70(8):745-52.

462. Luo H, Lv XD, Wang GE, Li YF, Kurihara H, He RR. Anti-inflammatory effects of anthocyanins-rich extract from bilberry (Vaccinium myrtillus L.) on croton oil-induced ear edema and Propionibacterium acnes plus LPS-induced liver damage in mice. Int J Food Sci Nutr. 2014;65(5):594-601.

\section{Submit your next manuscript to BioMed Central and we will help you at every step:}

- We accept pre-submission inquiries

- Our selector tool helps you to find the most relevant journal

- We provide round the clock customer support

- Convenient online submission

- Thorough peer review

- Inclusion in PubMed and all major indexing services

- Maximum visibility for your research

Submit your manuscript at www.biomedcentral.com/submit

C Biomed Central 